\title{
KEPENTINGAN AMERIKA SERIKAT DALAM PROSES \\ DENUKLIRISASI KOREA UTARA
}

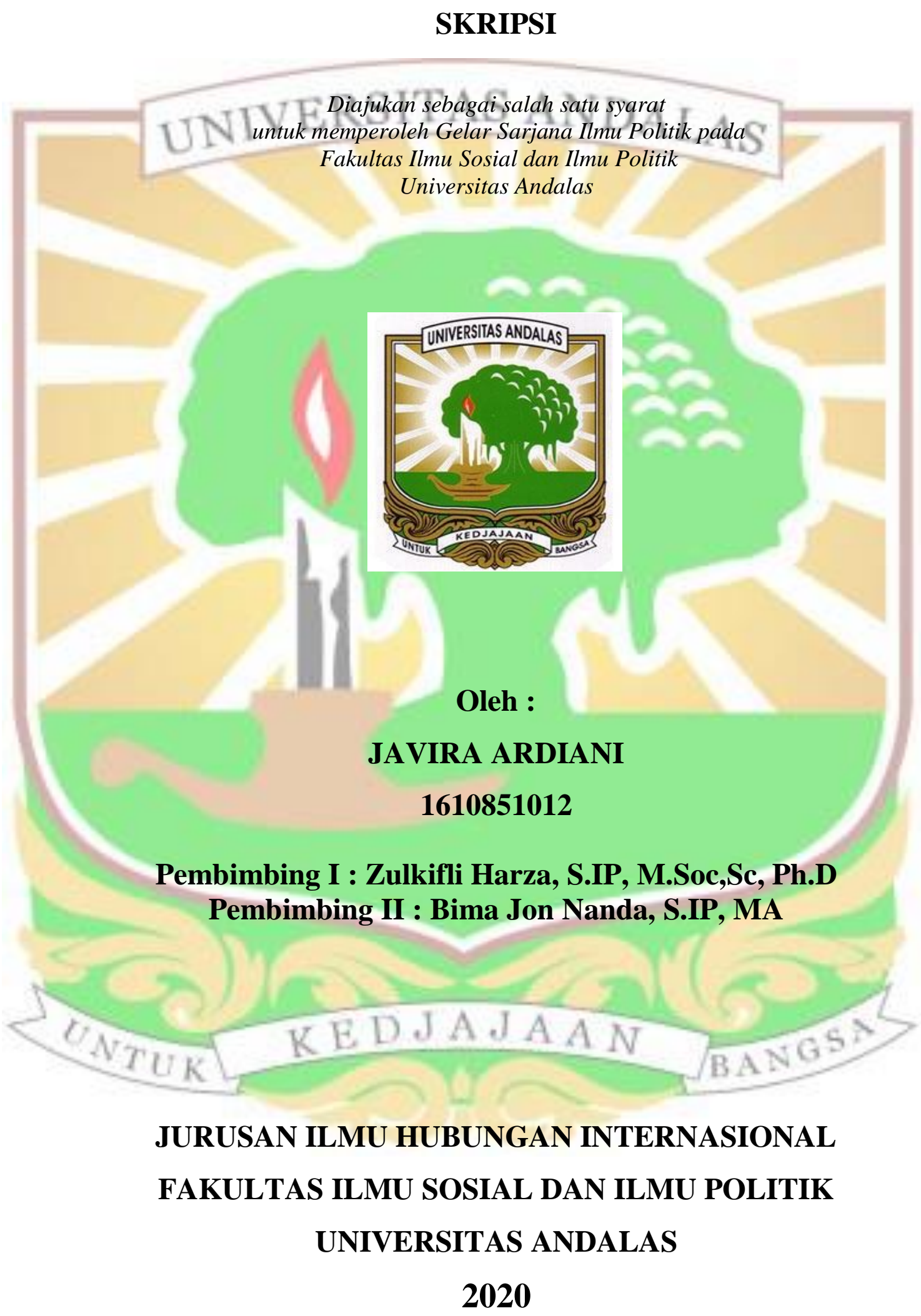




\section{JURUSAN ILMU HUBUNGAN INTERNASIONAL}

\section{FAKULTAS ILMU SOSIAL DAN ILMU POLITIK}

\section{UNIVERSITAS ANDALAS}

PADANG

\section{LEMBAR PENGESAHAN SKRIPSI}

Skripsi dengan judul Kepentingan Amerika Serikat dalam Proses Denuklirisasi Korea Utara atas nama Javira Ardiani ini telah diuji dan dipertahankan di depan tim penguji serta diterima untuk memenuhi sebagian persyaratan guna memperoleh gelar sarjana Ilmu Politik pada:

$\begin{array}{ll}\text { Hari / Tanggal } & : \text { Senin / } 6 \text { Januari } 2020 \\ \text { Jam } & : 08.00-09.20 \\ \text { Tempat } & : \text { Ruang Sidang Jurusan Ilmu Hubungan } \\ & \text { Internasional, gedung Jurusan FISIP Lantai } 2 .\end{array}$

Tim Penguji

\begin{tabular}{|l|l|l|}
\hline No. & \multicolumn{1}{|c|}{ Nama } \\
\hline 1. & Haiyyu Darman Moenir, S.IP, M.Si \\
NIP. 198012212010121003 & Kabatan \\
\hline 2. & $\begin{array}{l}\text { Inda Mustika Permata, S.IP, M.A } \\
\text { NIP. 199112262019032015 }\end{array}$ \\
\hline 3. & $\begin{array}{l}\text { Silvi Cory, S.Pd, M.Si } \\
\text { NIP. 198604212019032012 }\end{array}$ \\
\hline 4. & $\begin{array}{l}\text { Zulkifli Harza, Ph.D } \\
\text { NIP. 197008312009121003 }\end{array}$ \\
\hline 5. Bima Jon Nanda, S.IP, M.A & Pekretaris \\
\hline
\end{tabular}

Mengetahui,

Dekan Fakultas Ilimu Sosial dan Ilmu Politik

Universntas Andalas

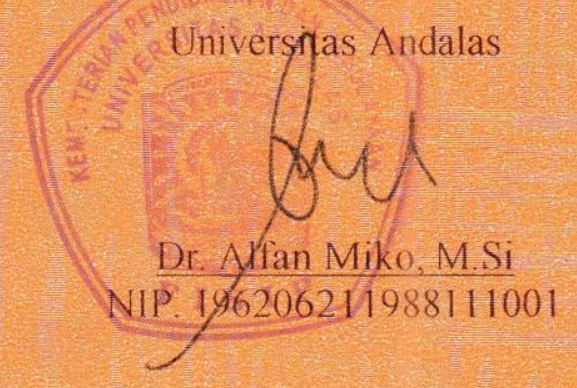




\section{SURAT PERNYATAAN}

Dengan ini saya menyatakan bahwa:

1. Karya tulis yang berjudul "Kepentingan Amerika Serikat dalam Proses Denuklirisasi Korea Utara" ini belum pernah diajukan untuk mendapatkan gelar akademik (sarjana, magister, dan/atau doktor), baik di Universitas Andalas maupun di perguruan tingi lainnya.

2. Karya tulis ini murni gagasan, penilaian, dan perumusan saya sendiri, kecuali bantuan dan arahan dari pihak-pihak yang disebutkan di dalam kata pengantar.

3. Dalam karya tulis ini tidak terdapat karya atau pendapat yang telah ditulis ataupun dipublikasikan orang lain, kecuali secara tertulis dengan jelas yang dicantumkan sebagai acuan dalam naskah dengan disebutkan nama pengarang dan dicantumkan di dalam Daftar Pustaka.

4. Pernyataan ini saya buat dengan sebenarnya dan apabila dikemudian hari terdapat penyimpangan dan ketidakbenaran dalam pernyataan ini, maka saya bersedia menerima sanksi akademik berupa pencabutan gelar yang telah diperoleh karena karya tulis ini, serta sanksi lainnya sesuai dengan norma yang berlaku di perguruan tinggi ini.

Padang, 14 Januari 2020

Yang Menyatakan

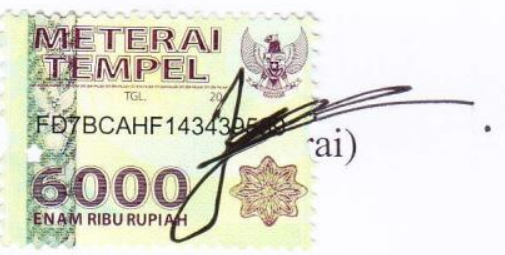

Javira Ardiani

NIM. 1610851012 


\section{HALAMAN PERNYATAAN PERSETUJUAN PUBLIKASI TUGAS AKHIR UNTUK KEPENTINGAN AKADEMIS}

Saya mahasiswa Universitas Andalas yang bertanda tangan di bawah ini: Nama Lengkap : Javira Ardiani

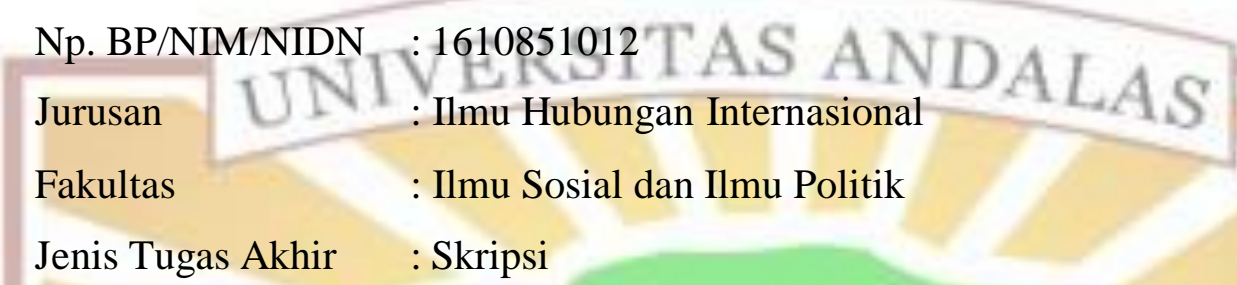

Demi pengembangan ilmu pengetahuan, menyetujui untuk memberikan kepada Universitas Andalas hak atas publikasi dari tugas akhir saya yang berjudul:

\section{Kepentingan Amerika Serikat dalam Proses Denuklirisasi Korea Utara}

Beserta perangkat yang ada (jika diperlukan). Univeristas Andalas juga berhak untuk menyimpan, mengalih media/formatkan, mengelola, merawat dan mempublikasikan karya saya tersebut selama tetap mencantumkan nama saya sebagai penulis/pencipta dan sebagai pemilik hak cipta. Demikian pernyataan ini saya buat dengan sebenarnya.

Padang, 14 Januari 2020

Yang Menyatakan,

Javira Ardiani

NIM: 1610851012

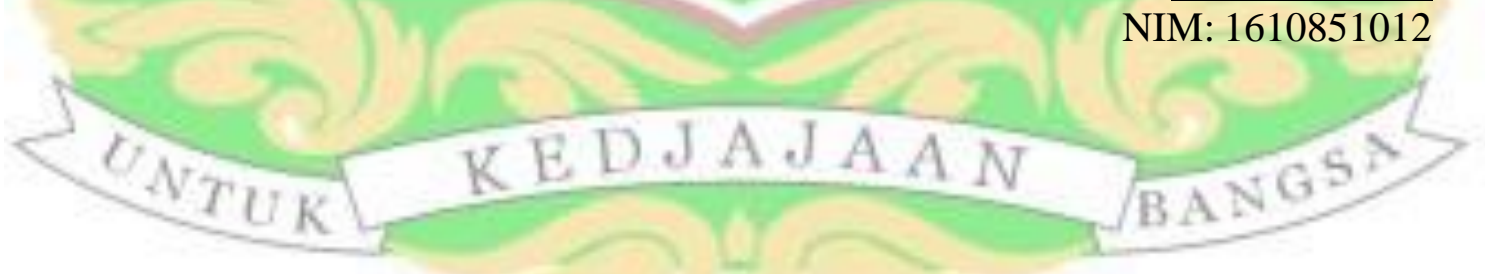




\section{KATA PENGANTAR}

\section{Bismillahirromahirrohim.}

Puji syukur kehadirat Allah SWT yang telah memberikan keberkahan serta rahmat-Nya kepada penulis untuk menyelesaikan skripsi yang berjudul; “Kepentingan Amerika Serikat dalam Proses Denuklirisasi Korea Utara”. Di samping itu, penulis menyadari bahwa penelitian ini masih jauh dari kesempurnaan karena terdapat keterbatasan pengetahuan yang penulis miliki. Dalam kesempatan ini, penulis ingin mengucapkan terima kasih kepada semua pihak yang telah membantu, menyemangati, dan medoakan penulis dalam penulisasan skripsi ini, yaitu terutama kepada:

1. Kedua Orang tua tercinta, ayah dan ibu penulis, Armen dan Eneng Maryani, saudara penulis, Novi, Rama, Marwan, dan Wanda, terima kasih telah memberikan dukungan secara moril dan materil terhadap proses perkuliahan penulis, sehingga penulis dapat menyelesaikan pendidikan untuk memperoleh gelar sarjana ini.

2. Bapak Zulkifli Harza S.IP, M.Soc.Sc sebagai Dosen Pembimbing I dan Bapak Bima Jon Nanda S.IP, M.A yang memiliki kontribusi besar dalam penyelesaian skripsi penulis, yakni seperti telah meluangkan waktu untuk penulis agar mudah untuk berkonsultasi, memberikan saran dan nasihat kepada penulis dalam pengarahan penulisan yang lebih baik pada penyelesaian skripsi ini.

3. Para penguji skripsi penulis yaitu Bapak Haiyyu Darman Moenir, S.IP, M.Si sebagai ketua penguji, Ibu Inda Mustika Permata, S.IP, MA sebagai sekretaris penguji dan Ibu Silvy Cory, S.Pd, M.Si, terimakasih karena telah memberikan saran yang membangun untuk skripsi penulis sehingga skripsi ini menjadi jauh lebih baik.

4. Seluruh dosen dan staf Ilmu Hubungan Internasional, terimakasih karena telah mendidik dan membimbing penulis selama menjalani proses perkuliahan.

5. Kak Tika yang telah penulis anggap sebagai kakak sendiri, (sekali lagi) terimakasih karena selalu mendukung penulis baik dari segi moril maupun 
materil, terimakasih karena selalu bersedia memberikan masukan dan saran untuk tulisan penulis, khususnya skripsi ini.

6. Sahabat terbaik di kehidupan perkuliahan, Odea yang selalu menemani penulis baik saat kuliah maupun untuk sekedar merenung di halte bus, terimakasih karena selalu ada di saat penulis merasa kesepian, dan telah menjadi rekan diskúsi yâng asik.

7. Ni Pit yang selalu menjadi tempat penulis untuk mencurahkan cerita, dan Intan yang selalu memberikan semangat untuk penulis. Terimakasih karena telah memberi dukungan dan mewarnai kehidupan perkuliahan penulis.

8. Sahabat-sahabat penulis, 'geng suduik' (Uni Vini, Cindy dan Fina) yang selalu memberikan perhatian walaupun jarang beretemu, Afdhaul yang telah banyak membantu penulis dalam keadaan apa pun.

9. Sahabat penulis sewaktu KKN, 'geng Cot', Sri yang selalu menjadi teman curhat dan bersedia menemani penulis, Mbak Evi yang sering membuatkan penulis makanan, Rani, dan Wanda yang selalu bersedia membantu penulis dan mengantarkan pasokan makanan untuk penulis.

10. Tania, teman sekamar yang telah penulis anggap sebagai adik sendiri, terimakasih karena selalu ada ketika penulis membutuhkan pertolongan, terimakasih untuk selalu memperhatikan kesehatan penulis yang terkadang lupa istirahat saat mengerjakan tugas kuliah maupun skripsi.

11. Del Piero Khaerullah yang selalu memberikan semangat dan perhatian di saat penulis sedang terpuruk, terimakasih karena selalu bersabar dalam menanggapi sifat penulis yang kekanakan dan egois.

12. Teman-teman HI angkatan 16 yang sangat luar biasa, terimakasih telah banyak membantu selama perkuliahan. Untuk Reki dan Sheryn yang samasama berjuang untuk bisa wisuda februari. Untuk Najib, Khairul, Okra, Vira, dan teman-teman lainnya yang tidak disebutkan satu persatu.

13. Keluarga besar jurusan Ilmu Hubungan Internasional yang telah memberikan banyak pengalaman hidup kepada penulis. 
14. Diri sendiri, terimakasih karena telah mau berjuang untuk mengerjakan skripsi ini sambil terus menghadapi segala permasalahan di kehidupan yang tiada habisnya.

15. Semua pihak yang telah membantu penulis baik secara langsung maupun tidak langsung dalam proses penyelesaian skripsi ini namun tidak dapat disebutkan satu per satu.SITAS ANDALAS

Penulis menyadari bahwa skripsi ini jauh dari sempurna, maka dari itu penulis berharap mendapat kritikan dan saran yang membangun dari semua pihak sehingga tulisan ini menjadi lebih baik. Penulis berharap skripsi ini nantinya dapat memberikan manfaat tidak hanya bagi penulis, tetapi juga bagi pihak-pihak lain yang terkait.

Padang, 14 Januari 2020

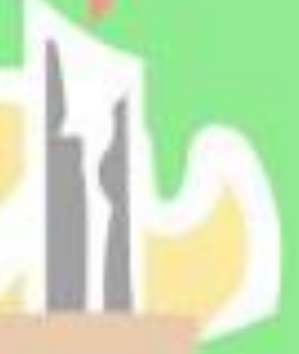

Penulis,

Javira Ardiani 


\begin{abstract}
ABSTRAK
Amerika Serikat merupakan negara yang berupaya untuk mewujudkan denuklirisasi di Semenanjung Korea. Padahal Amerika Serikat bukanlah pihak yang akan terancam secara langsung karena Amerika Serikat sendiri memiliki kemampuan senjata nuklir yang lebih kuat dibandingkan kapabilitas nuklir Korea Utara. Penelitian ini bertujuan untuk mendeskripsikan kepentingan Amerika Serikat sebagai Status Quo State dalam proses denuklirisasi Korea Utara. Kerangka konsep yang digunakan oleh penelitian ini adalah konsep Range of State Interest milik Randall L. Schweller. Penelitian ini menggunakan metode penelitian kualitatif dengan jenis penelitian deskriptif analitis yang menggunakan data-data sekunder. Berdasarkan konsep Range of State Interest, penelitian ini menemukan bahwa Amerika Serikat sebagai negara 'Lion' memiliki kepentingan untuk maximizing security yang meliputi mempertahankan identitasnya sebagai negara pemilik nuklir, mempertahankan perdagangan dengan negara-negara Asia Timur, dan meningkatkan fungsional pemerintahan. Sedangkan dalam mempertahankan posisi, Amerika Serikat berkepentingan untuk mempertahankan aliansinya dengan Korea Selatan dan Jepang, mempertahankan prestise untuk perdamaian dunia, serta mewujudkan CVID (Complete, Verifiable, and Irreversible Dismantlement) atau denuklirisasi penuh.
\end{abstract}

Kata Kunci : Amerika Serikat, Denuklirisasi, Kepentingan, Korea Utara, Status Quo State 


\begin{abstract}
The United States is a country that seeks to realize denuclearization in Korean Peninsula. Though the United States is not a party that will be directly threatened because the United States have more stronger nuclear capability than North Korea's nuclear. This study aims to describe the interests of the United States as a Status Quo State in the process of denuclearization of North Korea. The conceptual framework used by this study is Randall L. Schweller's Range of State Interest concept. This research uses a qualitative research method with descriptive analytical research that uses secondary data. Based on the concept of Range of State Interest, this research found that the United States as a 'Lion' country has an interest in maximizing security which includes maintaining its identity as a nuclear possession country, maintaining trade with East Asian countries, and improving governmental functions. Whereas in maintaining its position, the United States has an interest in maintaining its alliance with South Korea and Japan, maintaining prestige for world peace, and realizing CVID (Complete, Verifiable, and Irreversible Dismantlement) or full denuclearization.
\end{abstract}

Keywords: United States, Denuclearization, Interest, North Korea, Status Quo State

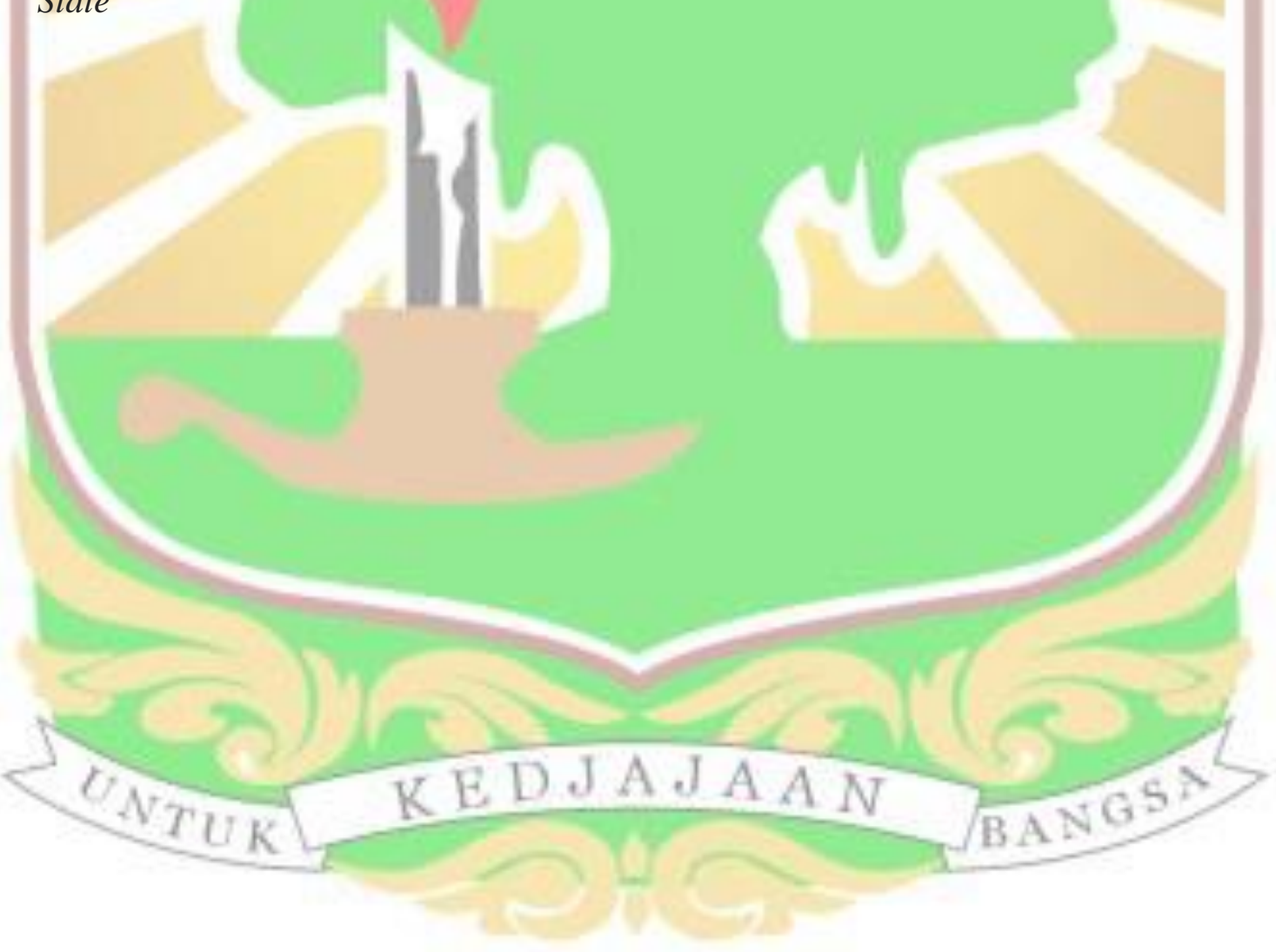


DAFTAR ISI

LEMBAR PERSETUJUAN SKRIPSI .................................... i

LEMBAR PENGESAHAN SKRIPSI....................................... ii

LEMBAR PERNYATAAN?...I.T.................................... ii

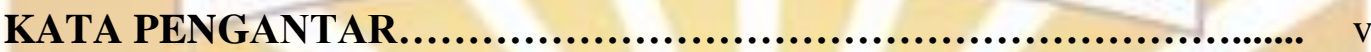

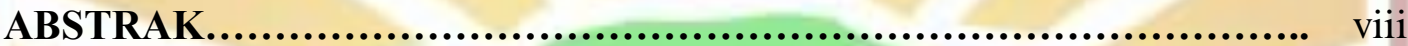

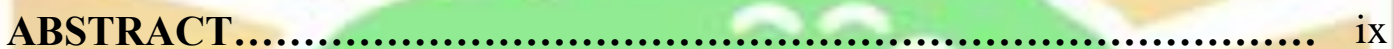

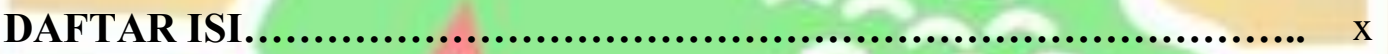

DAFTAR GAMBAR.................................................... xiv

DAFTAR GRAFIK...................................................... xiv

DAFTAR TABEL ............................................................ XV

DAFTAR SINGKATAN................................................... xvi

BAB I PENDAHULUAN

1.1 Latar Belakang......................................................... 1

1.2 Rumusan Masalah.................................................... 6

1.3 Pertanyaan Penelitian................................................. 6

1.4 Tujuan Penelitian........................................................ 7

1.5 Manfaat Penelitian....................................................... 7

1.6 Studi Pustaka ........................................................

1.7 Kerangka Konseptual............................................ 12

1.7.1 Status Quo vs Revisionist State ....................................... 12

1.7.2 Range of State Interest........................................... 14

1.8 Metode Penelitian..................................................... 19 
1.8.1 Jenis dan Pendekatan Penelitian............................... 19

1.8.2 Batasan Penelitian.............................................. 19

1.8.3 Unit Analisis, Unit Eksplanasi, dan Tingkat Analisis.............. 20

1.8.4 Teknik Pengumpulan Data.................................. 21

1.8.5 Teknik Analisis Data....................................... 22

1.9 Sistematika Penulisan................................................. 23

\section{BAB II NUKLIR KOREA UTARA DAN DINAMIKA POLITIK}

\section{KAWASAN ASIA TIMUR}

2.1 Pengembangan Senjata Nuklir Korea Utara........................... 25

2.1.1Motif Pengembangan Senjata Nuklir Korea Utara................ 27

2.1.2 Uji Coba Nuklir Korea Utara................................... 29

2.2 Dinamika Hubungan Korea Utara dengan Negara-negara Kawasan Asia Timur.

2.2.1 Dinamika Hubungan Korea Utara dan Korea Selatan.............. 33

2.2.2 Dinamika Hubungan Korea Utara dan Tiongkok................ 36

2.2.3 Dinamika Hubungan Korea Utara dan Jepang..................... 40

2.3 Nuklir Korea Utara dalam Politik Internasional..................... 42

2.4 Korea Utara sebagai Revisionist State ........................... 43

\section{BAB III UPAYA AMERIKA SERIKAT DALAM PROSES}

\section{DENUKLIRISASI KOREA UTARA}

3.1 Ancaman Nuklir Korea Utara terhadap Amerika Serikat................ 47

3.2 Upaya Amerika Serikat dalam proses Denuklirisasi Korea Utara......... 50

3.2.1 Upaya Amerika Serikat melalui Six Party Talks.................. 51

3.2.2 Upaya Amerika Serikat dalam Pembentukan Resolusi Dewan 
Keamanan PBB (UNSCR)

3.2.3 Upaya Amerika Serikat melalui Pivot to Asia...................... 52

3.2.4 Upaya Amerika Serikat melalui Strategic patience................. 56

3.2.5 Upaya Amerika Serikat melalui USFK........................... 58

3.2.6 Upaya Amerika Serikat melalui penempatan Terminal High Altitude

Area Defense (THAAD) di Korea Selatan

3.2.7 Upaya Amerika Serikat melalui Pertemuan Bilateral.

62

\section{BAB IV KEPENTINGAN AMERIKA SERIKAT DALAM PROSES}

\section{DENUKLIRISASI KOREA UTARA}

4.1 Hubungan Amerika Serikat dengan Negara di Kawasan Asia Timur........ 66

4.1.1 Perjanjian Aliansi Amerika Serikat dan Korea Selatan................ 67

4.1.2 Hubungan Amerika Serikat dan Jepang............................ 70

4.1.3 Rivalitas Amerika Serikat dan Tiongkok...........................

4.1.4 Korea Utara dalam Pandangan Amerika Serikat................... 76

4.2 Amerika Serikat sebagai Status Quo State............................. 78

4.2.1 Amerika Serikat sebagai First Rank......................... 78

4.2.2 Tindakan Amerika Serikat sebagai Status Quo State............... 81

4.2.3 Amerika Serikat sebagai Negara 'Lion' ............................ 83

4.3 Korea Utara sebagai Negara 'Wolves' .................................. 83

4.4 Kepentingan Amerika Serikat Sebagai Lion State ...................... 85

4.4.1 Maximizing Security...................................... 86

4.4.2 Mantaining position.......................................... 91

BAB V PENUTUP

5.1 Kesimpulan. 96 
DAFTAR PUSTAKA................................................. 100

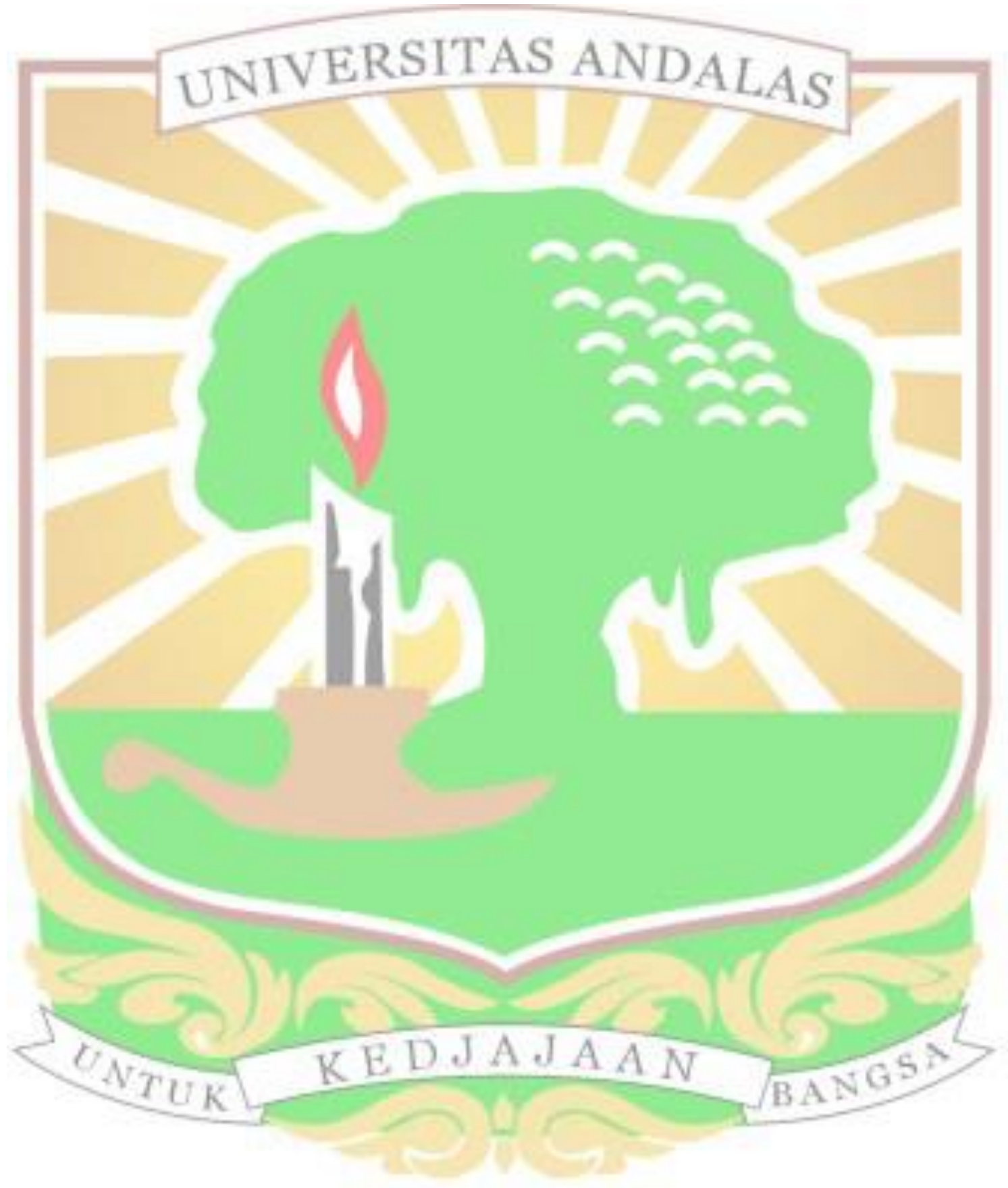




\section{DAFTAR GAMBAR}

Gambar 2.1 Gambar Peta Asia Timur.

Gambar 4.1 Respon Publik Korea Selatan terkait Mitra Keamanan paling

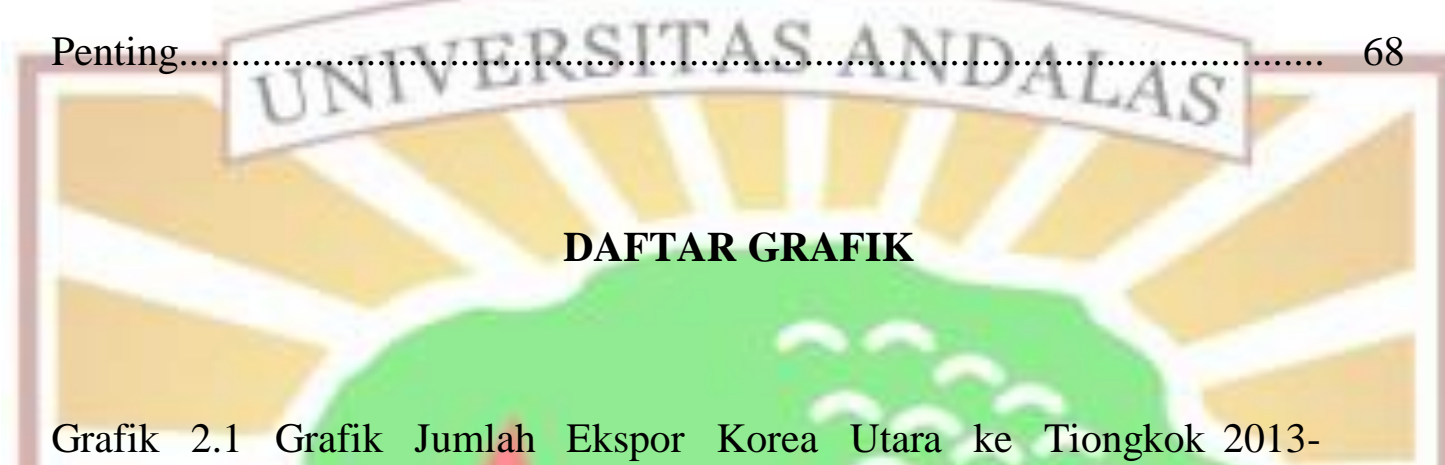
2017(dalam Juta USD)

Grafik 2.2 Grafik Jumlah Impor Korea Utara ke Tiongkok 20132017(dalam Juta USD)...

Grafik 4.1 Anggaran Dasar pertahanan Amerika Serikat 2013-2018 (dalam juta Dolar Amerika Serikat) 


\section{DAFTAR TABEL}

Tabel 1.1 Range of State Interest.......................................................... 15

Tabel 2.1 Tabel Kemampuan Uji Coba Nuklir Korea Utara...................... 30

Tabel 3.1 Jumlah Kepemilikan Senjata Nuklir Negara.............................. 48

Tabel 3.2 Kemampuan Misil Balistik Korea Utara...................................... 49

Tabel 3.3 Military Strength and Employment of USFK................................ 59

Tabel 4.1 Kapabilitas Nuklir Korea Utara................................................. 76

Tabel 4.2 Posisi negara kekuatan militer terkuat di dunia........................... 78

Tabel 4.3 Negara-Negara Posisi Perekonomian Teratas............................. 80

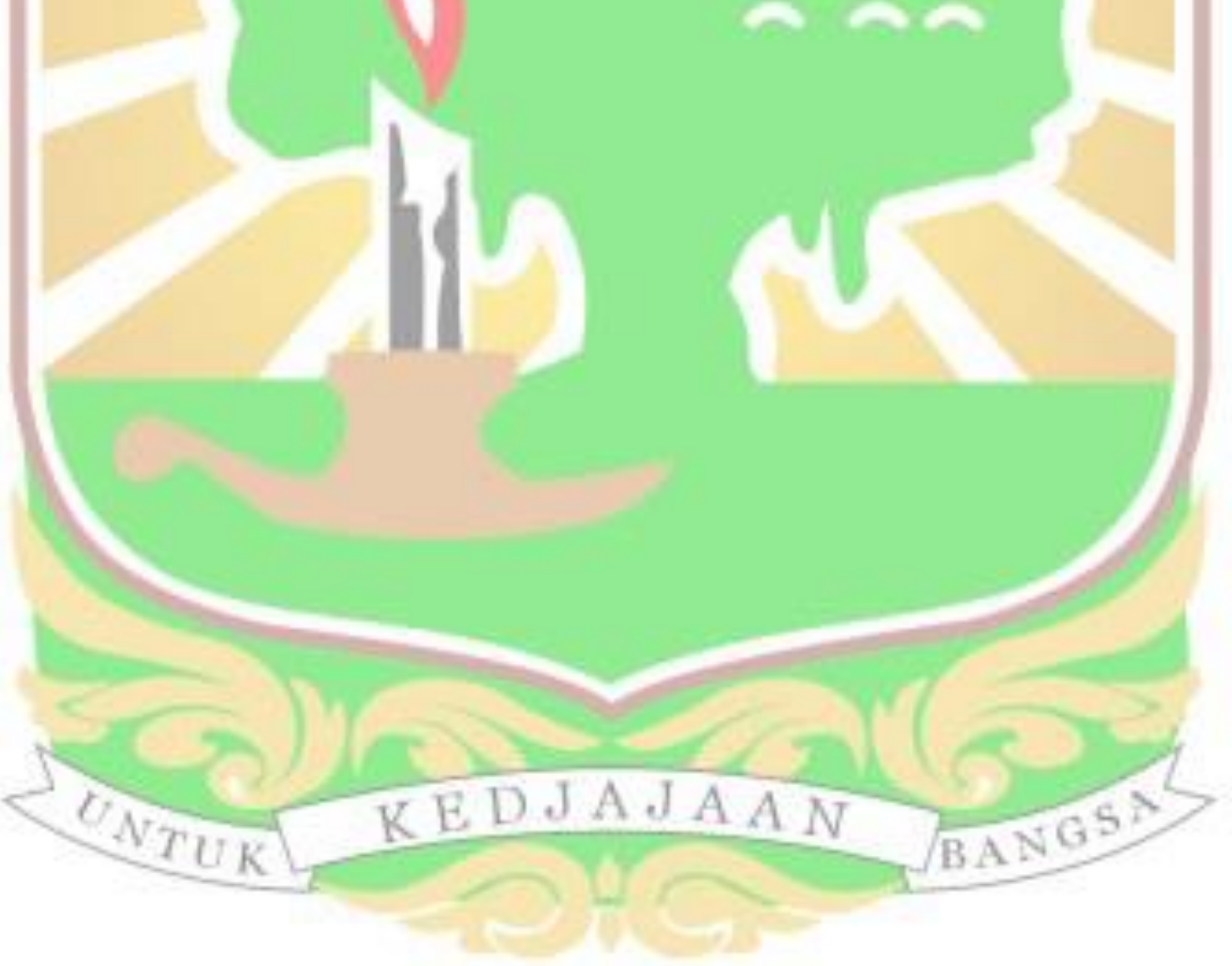




\section{DAFTAR SINGKATAN}

BMD Ballistic Missile Defense

CVID Complete, Verifiable, and Irreversible Dismantlement

$\begin{array}{ll}\text { GDP } & \text { Gross Domestic Product S ANDALAS } \\ \text { GFP } & \text { Global Fire Power } \\ \text { IAEA } & \text { International Atonomic Energy Agency } \\ \text { KTT } & \text { Konferensi Tingkat Tinggi } \\ \text { NPT } & \text { Nuclear Non-Proliferation Treaty } \\ \text { PBB } & \text { Perserikatan Bangsa Bangsa } \\ \text { SDF } & \text { Self Defense Force } \\ \text { THAAD } & \text { Terminal High Altitude Area Defense } \\ \text { UNSCR } & \text { United Nations Security Council Resolutions } \\ \text { USFK } & \text { United States Force Korea }\end{array}$

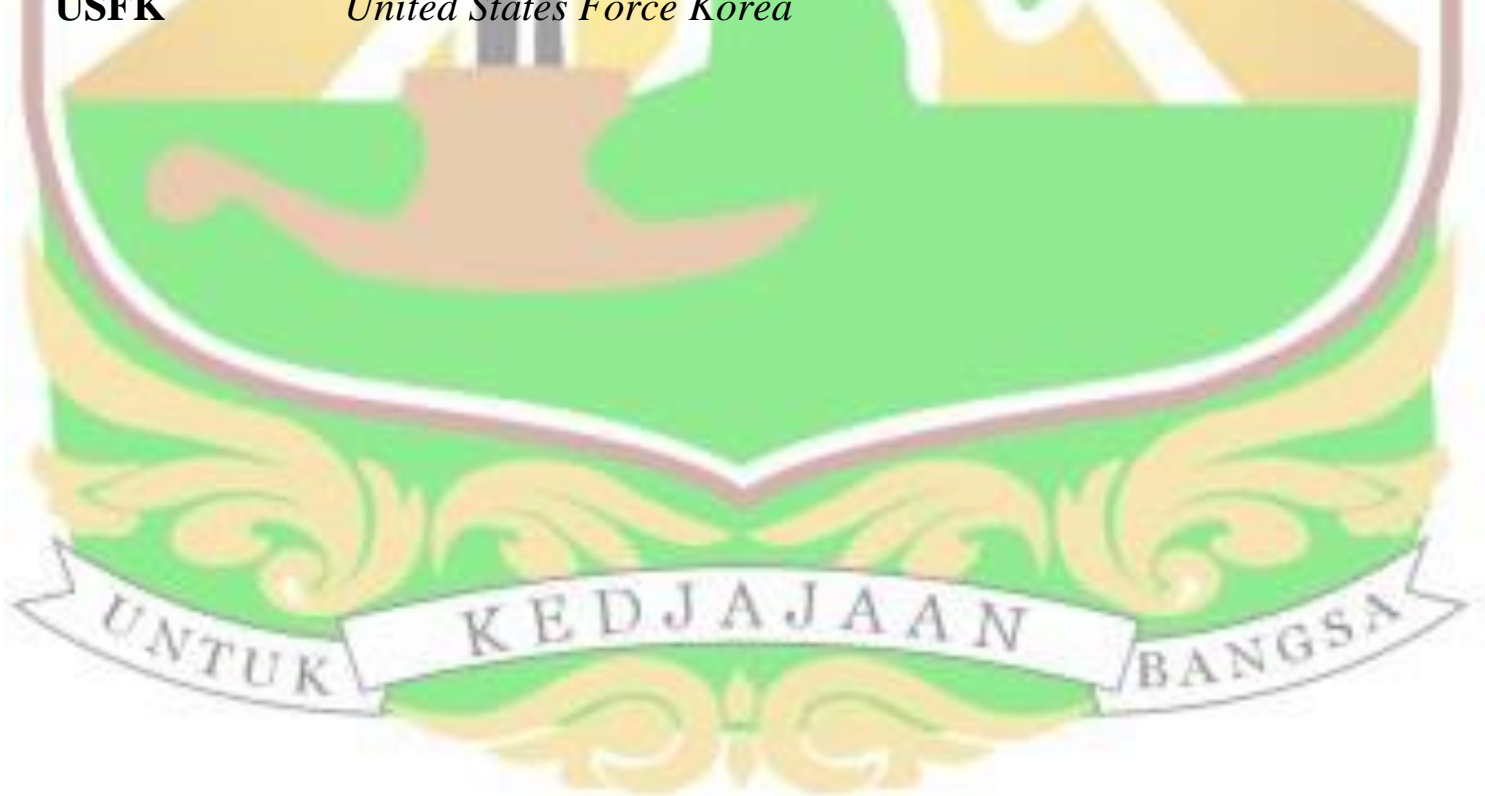




\section{BAB I}

\section{PENDAHULUAN}

\subsection{Latar belakang}

Pada 12 Juni 2018, Pemimpin Korea Utara, Kim Jong Un, dan Pemimpin Amerika Serikat, Donald Trump, melakukan pertemuan di Pulau Santosa, Singapura. Pertemuan ini merupakan pertemuan pertama antara pemimpin Korea Utara dan Amerika Serikat setelah sebelumnya sempat mengalami ketegangan akibat uji coba nuklir Korea Utara. Presiden Trump mengungkapkan bahwa semua pembicaraan berlangsung jauh lebih baik dari yang diperkirakan. Kim Jong Un juga menyatakan bahwa Korea Utara dan Amerika Serikat memutuskan untuk melupakan masa lalu. ${ }^{1}$ Hasil dari pembicaraan ini tentunya akan berpengaruh terhadap keberlanjutan pengembangan nuklir Korea Utara karena membicarakan persoalan denuklirisasi secara penuh di Semenanjung Korea.

Berbicara mengenai nuklir Korea Utara, Amerika Serikat merupakan pihak yang gigih dalam menciptakan denuklirisasi di Semenanjung Korea. Padahal, Amerika Serikat sendiri bukanlah negara Asia Timur yang akan langsung terancam oleh pengembangan nuklir Korea Utara. Amerika Serikat berada cukup jauh dari letak Asia Timur yang berada di $26^{\circ} \mathrm{LU}-48 \mathrm{LU}^{\circ}$ dan $67^{\circ} \mathrm{BB}-125^{\circ} \mathrm{BB}$. Hal ini membuat keterlibatan Amerika Serikat di Asia Timur sebenarnnya akan menimbulkan biaya dan upaya yang tidak sedikit seperti pelatihan gabungan, pemasangan THAAD, dan pengiriman armada perang. ${ }^{2}$

\footnotetext{
${ }^{1}$ BBC News Indonesia. Kim-Trump tandatangani 'kesepakatan' : Hubungan AS-Korut akan berbeda sama sekali. Diakses dari https://www.bbc.com/indonesia/amp/dunia-44447915 pada januari 2019

${ }^{2}$ Fransminggi Kamasa. Perang Korea. Pustaka Narasi .2014. Hlm 73
} 
Selain itu, jumlah nuklir Amerika Serikat telah mencapai 6.185 total inventaris. ${ }^{3}$ Jumlah ini jauh lebih tinggi dibandingkan nuklir milik Korea Utara yang hanya diperkirakan berjumlah 20-30 total inventaris. ${ }^{4}$ Perbandingan ini menunjukan bahwa kemampuan nuklir Korea Utara bukanlah ancaman yang serius bagi Amerika Serikat. Namun, tak bisa dihindari fakta bahwa kesepākatan aliansi militer antara Amerika Serikat dan Korea Selatan yang telah berlangsung selama puluhan tahun membuat Amerika Serikat terus mengambil tindakan dalam stabilitas keamanan Semenanjung Korea.

Hal tersebut dikarenakan dalam kesepakatan dinyatakan bahwa kedua negara akan saling melindungi jika ada ancaman dari pihak ketiga. Disini, Amerika Serikat berupaya untuk melindungi Korea Selatan dari ancaman nuklir Korea Utara. Namun, Korea Selatan dan Amerika Serikat sendiri memiliki pandangan yang berbeda terkait pendekatan untuk menanggapi Korea Utara. Terlepas dari hambatan tersebut yang menjadi keunikan dalam hal ini ialah Amerika Serikat terus terlibat dalam proses Denuklirisasi Korea Utara yang diklaim sebagai upaya menciptakan perdamaian di Semenanjung Korea.

Keterlibatan Amerika Serikat bukan hanya dalam hal mendukung perdamaian Semenanjung Korea, tetapi juga pengambilan tindakan yang kontradiktif dengan tujuan perdamaian. Terkadang, tindakan yang diambil Amerika Serikat justru membuat denuklirisasi semakin jauh untuk dicapai. Keterlibatan tersebut dapat dilihat dari upaya diplomasi multilateral Six Party Talks, keberadaan pasukan militer AS di Korsel dan Jepang yang berpengaruh dengan dinamika politik dan keamanan di Asia Timur terutama pada masa

\footnotetext{
${ }_{3}^{3}$ SIPRI. "Armaments, Disarmament and International Security". 2019 : hlm. 11

${ }^{4}$ SIPRI. hlm. 11
} 
Pemerintahan Presiden Barack Obama, serta pembuatan Pengoperasian sistem pertahanan rudal Terminal High Altitude Area Defense (THAAD) di Semenanjung Korea. $^{5}$

Kembali lagi pada Agustus 2003, Six Party Talks dibentuk sebagai serangkaian upaya perundingan untuk mengakhiri program nuklir Korea Utara. Upaya multilateral ini berupaya menggandeng Korea Utara bergabung ke dalam meja perundingan melalui proses negosiasi yang melibatkan Amerika Serikat, Rusia, Jepang, Tiongkok, dan Korea Selatan. ${ }^{6}$ Perundingan pertama Six Party Talks yang dimulai pada 27 Agustus 2003 di Beijing membahas mengenai normalisasi hubungan Korea Utara dengan Amerika Serikat serta normalisasi hubungan Korea Utara dengan Korea Selatan. Namun perundingan ini tidak memberikan dampak yang baik. Sebaliknya, Amerika Serikat justru memberikan sanksi ekonomi kepada Korea Utara.

Kemudian, sejak dikeluarkannya kesepakatan Joint Declaration of the Denuclearization of the Korean Peninsula pada 1992, muncul beberapa fenomena yang membuat hubungan Korea Utara dan Korea Selatan semakin memburuk karena kesepakatan tersebut tidak terealisasi dengan baik. Pada tahun 2009, Korea Utara secara terang-terangan melakukan uji coba rudal balistik di sekitar laut Jepang. Hal ini membuat hubungan Korea Utara dan Korea Selatan yang sebelumnya membaik malah berbalik menjadi buruk. Peran Amerika Serikat pada tahap ini ialah mendorong terbentuknya United Nations Security Council

\footnotetext{
${ }_{5}^{5}$ Mega Aldikawati. "Dinamika Hubungan Korea Utara-Korea Selatan dan Dampaknya Terhadap Stabilitas Keamanan di Kawasan Asia Timur Pasca Perang Dingin” Reunifikasi Korea , 2012: 45

${ }^{6}$ Muhammad Nabil. "Diplomasi Multilateral Six Party Talks Dalam Proses Denuklirisasi Korea Utara Periode 2003-2009.” Jurnal Ilmu Hubungan internasional, 2014: 3.
} 
Resolution (UNSCR) pada tahun 2009 terkait keamanan Asia Timur, yaitu Resolusi 1887 dan Resolusi $1874 .^{7}$

Kemudian, saat Kim Jong-un dilantik sebagai pemimpin Korea Utara pada tahun 2011, Korea Utara lebih provokatif dibandingkan pemerintah sebelumnya. Pada pertengahan 2011, Pemerintahan Obama mengumumkan kebijakan luar negeri Amerika Serikat akan fokus ke Asia dengan slogan "Pivot to Asia". ${ }^{8}$ Dalam kebijakan ini juga termasuk didalamnya aliansi militer bersama Korea Selatan dan Jepang sebagai basis pertahanan Asia, khususnya untuk mengatasi ancaman Korea Utara.

Kerjasama dan aliansi keamanan dengan Korea Selatan untuk memperkuat keamanan domestik Korea Selatan dari ancaman keamanan kawasan, dilakukan dengan transfer teknologi persenjataan dan penempatan pasukan militer di Korea Selatan. Hal ini merupakan bentuk implementasi kesepakatan yang telah dibuat sebelumnya (Mutual Defense Treaty). Jumlah pasukan militer Amerika Serikat di Korea Selatan hampir mencapai 35.000 pasukan pada tahun $2016 .{ }^{9}$ Amerika Serikat juga telah mendesak Korea Selatan untuk mengembangkan atau memperoleh kemampuan BMD (Ballistic Missile Defense) yang canggih dan mengintegrasikannya dengan sistem BMD Amerika Serikat dan sekutu di wilayah ini. Hal ini dinamakan Terminal High Area Defense (THAAD) sebagai upaya pertahanan rudal balistik.

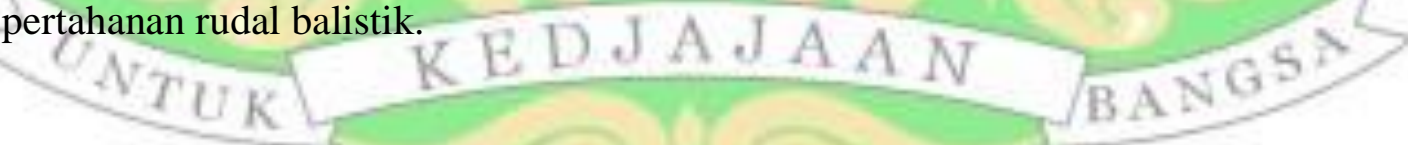

\footnotetext{
${ }^{7}$ Edward Giovanny Marpaung. "Aliansi Militer Amerika Serikat Dan Korea Selatan Dalam Upaya Menjaga Stabilitas Keamanan Semenanjung Korea (2010-2016)”. Universitas komputer Indonesia. 2017: hlm. 4

${ }^{8}$ Mega Aldikawati. Hlm. 52

${ }^{9}$ Edward Giovanny Marpaung. hlm. 8
} 
Selain itu, Amerika Serikat dengan Jepang juga saling bersepakat dalam perjanjian keamanan dan aliansi bersama. Kehadiran Amerika Serikat di kawasan justru semakin menjadi ancaman bagi negara non-aliansi Amerika Serikat termasuk Korea Utara, intervensi Amerika Serikat di kawasan dipandang sebagai upaya untuk mengancam Keamanan nasionalnya. ${ }^{0}$ Dibawah pemerintahan Obama, Amerika Serikat pun menerapkan strategi 'Strategic Patience' untuk menanggapi permasalahan Korea Utara, yang mana kebijakan ini mengupayakan adanya negosiasi dengan Korea Utara terkait denuklirisasi dengan cara 'Wait' dan pemberian tekanan terhadap Korea Utara. ${ }^{11}$

Namun, pada awal tahun 2017 Presiden Donald Trump melalui deklarasi Wakil Presiden, Mike Pence menyatakan bahwa kebijakan keamanan Amerika Serikat 'Strategic Patience' telah berakhir. Amerika Serikat berada dalam kondisi dilematis. Intervensi militer yang digencarkan terhadap Korea Utara pasti akan menyebabkan kerugian luar biasa tidak hanya bagi kedua negara tetapi juga negara lain di kawasan, bahkan serangan militer bisa memicu terjadinya perang nuklir global.

Sebelum melakukan pertemuan bilateral dengan Kim Jong Un, Donald Trump juga mendukung pertemuan bilateral antara Korea Utara dan Korea Selatan pada 27 April 2018. Setelah pertemuan bilateral Korea Utara-Korea Selatan, Presiden Trump merencanakan pertemuan dengan Kim Jong-un yang akan melakukan 2 pembahasan nuklir. Pertemuan tersebut diharapkan mampu menghasilkan komitmen untuk melakukan denuklirisasi dan menangguhkan uji

\footnotetext{
${ }^{10}$ M. Najeri Al Syahrin. "Logika Dilema Keamanan Asia Timur Dan Rasionalitas Pengembangan Senjata Nuklir Korea Utara.” Hlm 125

${ }^{11}$ Krisandhy Ertanto Rantung. "Kebijakan Luar Negeri Amerika Serikat terhadap Program

Pengembangan Nuklir Korea Utara pada Masa Pemerintahan Barack Obama”. 2016 : hlm. 5
} 
coba rudal Korea Utara. Dengan terus aktifnya Amerika Serikat dalam upaya denuklirisasi Korea Utara, penting untuk mengetahui lebih lanjut kepentingan yang hendak dipenuhi Amerika Serikat dalam upaya ini.

\subsection{Rumusan Masalah}

KTT Singapura 2018 merupakan pertemuan antara kedua pemimpin negara yaitu Amerika Serikat dan Korea Utara. Pertemuan ini membahas mengenai denuklirisasi di Semenanjung Korea. Jika membahas mengenai isu nuklir Korea Utara, maka dapat dilihat bahwa Amerika Serikat merupakan negara yang selalu mengupayakan adanya denuklirisasi, baik secara diplomatik, maupun koersif seakan-akan terancam dengan adanya pengembangan nuklir Korea Utara. Padahal Amerika Serikat memiliki kapabilitas nuklir yang jauh lebih mumpuni dibandingkan nuklir Korea Utara. Selain itu, Amerika Serikat juga bukan negara kawasan Asia Timur yang akan terpengaruh langsung oleh nuklir Korea Utara.

Tentu saja, Amerika Serikat mengklaim bahwa upayanya dalam mewujudkan denuklirisasi didukung oleh Mutual Defense Treaty dengan Korea Selatan. Namun, Amerika Serikat dan Korea Selatan sendiri terkadang memiliki pandangan yang berbeda dalam menanggapi Korea Utara. ${ }^{12}$ Terlepas dari hal tersebut, Amerika Serikat tetap berusaha mewujudkan stabilitas keamanan Semenanjung Korea dengan cara terus mengupayakan denuklirisasi Korea Utara.

\subsection{Pertanyaan Penelitian}

Dari rumusan permasalahan yang telah dipaparkan tersebut, penulis menarik pertanyaan penelitian "Apa kepentingan Amerika Serikat dalam proses Denuklirisasi Korea Utara?"

\footnotetext{
${ }^{12}$ Edward Giovanny Marpaung. Aliansi Militer Amerika Serikat dan Korea Selatan dalam Upaya Menjaga Stabilitas Keamanan Semenanjung Korea (2010-2016). HIm 8
} 


\subsection{Tujuan Penelitian}

Dari penelitian ini, penulis bertujuan untuk mendeskripsikan tentang kepentingan Amerika Serikat dalam proses Denuklirisasi Korea Utara.

\subsection{Manfaat Penelitian ERSTTAS ANDALAS}

Penelitian yang dilakukan juga tentunya akan memiliki beberapa manfaat baik secara akademis maupun praktis. Untuk manfaat akademis sendiri, penelitian ini dapat membantu pembaca untuk memahami konsep kepentingan dari fenomena hubungan internasional yang terjadi, yaitu keterlibatan Amerika Serikat dalam denuklirisasi Korea Utara secara lebih dalam. Selain itu, penelitian ini juga bermanfaat secara praksis untuk menjadi referensi bagi khalayak maupun pengamat yang berfokus dalam respon terhadap fenomena atau hal-hal yang berkaitan dengan keamanan negara.

\subsection{Studi Pustaka}

Penulis akan menggunakan tulisan Nicholas D. Anderson yang berjudul “Explaining North Korea's Nuclear Ambitions : Power and position on the Korean Peninsula" untuk menjadi tinjauan pustaka. Hal yang menjadi permasalahan dalam tulisan Anderson ialah Korea Utara yang secara besar- besaran menguji coba senjata nuklirnya pada tahun 2016 ke Semenanjung Korea. Tindakan Korea tersebut

dikecam oleh banyak pihak, khususnya Korea Selatan, Jepang, dan Amerika

Serikat. Dari uji coba tersebut, Anderson berfokus untuk mengetahui motif Korea Utara dalam mengembangkan dan menguji coba senjata nuklirnya. 
Anderson menjelaskan bahwa terdapat dua argumen dasar mengenai motif Korea Utara dalam mengembangkan senjata nuklirnya. Argumen pertama yaitu 'doves' yang mengungkapkan bahwa terancamnya Korea Utara dari segi militer, politik, dan ekonomi membuat Korea Utara tetap bersikukuh untuk mempertahankan pengembangan senjata nuklirnya. ${ }^{13}$ Singkatnya, argumen pertama ini melihat bahwa aliansi Amerika Serikat dan Korea Selatan yang bekerjasama terutama di bidang militer, membuat Korea Utara merasa terancam. Hal tersebut dikarenakan Korea Utara merupakan 'musuh' dari Korea selatan dalam konflik Semenanjung Korea. Selain itu, baik Korea Selatan maupun Amerika Serikat juga memiliki ideologi yang bertolak belakang dengan Korea Utara.

Berbeda dengan argumen pertama, argumen 'Hawks' cenderung menitikberatkan bahwa psikologis, insentif politik domestik, dan motif revisionis merupakan pendorong utama bagi pengembangan senjata nuklir negara tersebut. ${ }^{14}$ Argumen ini berkaitan dengan ideologi Juche yang dianut oleh Korea Utara. Ideologi ini menyatakan bahwa yang menentukan takdir dari suatu negara ialah negara itu sendiri. Temuan dari tulisan Anderson membantu penulis dalam menjelaskan motif Korea Utara dalam mengembangkan nuklir senjata nuklir. Hal tersebut tentu akan berkaitan dengan tujuan penulis yaitu untuk menjelaskan kepentingan Amerika Serikat dalam proses denuklirisasi Korea Utara.

Selanjutnya, penulis juga mengambil tulisan "North Korea's Revolutionary Unification Policy" karya Sung-Yoon Lee. Tulisan ini diawali dengan pembahasan mengenai Revolusi dari Korea Selatan dari sejak terjadinya

\footnotetext{
${ }^{13}$ Nicholas D Anderson. "Explaining North Korea's Nuclear Ambitions : Power and Position on the Korean Peninsula." Australian Journal of International Affairs , 2017 : hlm. 2

${ }^{14}$ Nicholas D Anderson. hlm. 5
} 
Perang Korea. Selanjutnya dibahas pula mengenai Korea Utara yang cenderung agresif sehingga tindakan underestimating terhadap negara tersebut akan berbahaya. Lee sendiri berfokus untuk menjelaskan cara Korea Utara untuk mencapai reunifikasi. Dalam tulisannya, Lee menjelaskan bahwa senjata nuklir merupakan cara Korea Utara dalam menanggapi kasus reunifikasi secara revolusioner. $^{15}$

Tulisan Lee memperlihatkan bagaimana Korea Utara bertindak dalam merespon isu reunifikasi dengan Korea Selatan. Lee menjelaskan bahwa nuklir yang dikembangkan Korea Utara digunakan untuk menunjukan bahwa Korea Utara bukanlah negara lemah. Temuan ini berguna untuk membantu penulis dalam menjelaskan Korea Utara sebagai negara yang cenderung ingin mengubah atau merevisi posisinya di sistem internasional sebagai negara yang lemah. Hal ini juga akan berhubungan dengan tindakan yang diambil Amerika Serikat untuk mencapai kepentingannya di Asia Timur.

Selanjutnya, penulis juga memakai tulisan karya Poltak Partogi Nainggolan dalam Jurnal Politica yang berjudul "Kepentingan Strategis Amerika Serikat di Asia Pasifik". Tulisan ini membahas mengenai kepentingan Amerika Serikat di Asia Pasifik khususnya pada saat pemerintahan Presiden Obama. Nainggolan menjelaskan bahwa pengiriman pasukan ke negara-negara aliansi Amerika Serikat seperti Australia merupakan salah satu tindakan Amerika Serikat untuk mencapai kepentingannya di Asia Pasifik. ${ }^{16}$

\footnotetext{
${ }^{15}$ Lee, Sung Yoon. "North Korea's Revolutionary Unification Policy." Interational Journal of Korean Studies XVIII (2014): hlm. 131

${ }^{16}$ Poltak Partogi Nainggolan. "Kepentingan Strategis Amerika Serikat di Asia Pasifik." Politica 4 (2013). Hlm. 98
} 
Nainggolan menemukan bahwa kepentingan Amerika di Asia Pasifik tidak terlepas dari kepentingan ekonomi dan sumber daya alam. Selain itu, kepentingan lainnya ialah untuk mengimbangi dominasi Tiongkok di kawasan Asia Pasifik. Hal ini dikarenakan Tiongkok telah bangkit menjadi kekuatan ekonomi baru serta terus berupaya untuk meningkatkan anggaran belanja pertahanan negaranya. Tindakan Amerika Serikat dalam pengiriman pasukan di Pangkalan militer negara-negara Asia Pasifik dinilai Nainggolan sebagai cara untuk mengawasi Tiongkok. Dari temuan ini dijelaskan mengenai kepentingan Amerika Serikat di kawasan. Hanya saja, Nainggolan memiliki fokus kawasan yang lebih besar daripada penulis yaitu Asia Pasifik. Sedangkan, dalam tulisan ini penulis lebih berfokus terhadap kepentingan Amerika di Asia Timur, khususnya dalam isu denuklirisasi Korea Utara.

Studi pustaka pada penelitian kali ini juga akan memakai tulisan Xenia Dormandy dan Rory Kinane, yaitu “Asia-Pacific Security A Changing Role for the United States". Tulisan ini menjelaskan bahwa kebijakan Amerika Serikat terkait keamanan regional Asia Pasifik merupakan tantangan dan keinginan untuk mempromosikan hubungan persahabatan di kawasan Asia Pasifik. Namun, tulisan Dormandy dan Kinane ini merujuk kepada kondisi negara Asia Pasifik secara keseluruhan.

Berbeda dengan tulisan Dormandy dan Kinane, penulis memfokuskan pada kepentingan yang menjadi penyebab Amerika mengeluarkan kebijakan terhadap Asia Timur, khususnya dalam keterlibatannya dalam upaya denuklirisasi Semenanjung Korea. Keterlibatan tersebut dapat dilihat dari upaya diplomasi multilateral Six Party Talks, keberadaan pasukan militer Amerika Serikat di 
Korsel dan Jepang yang berpengaruh dengan dinamika politik dan keamanan di Asia Timur terutama pada masa Pemerintahan Presiden Barack Obama, serta pembuatan Pengoperasian sistem pertahanan rudal Terminal High Altitude Area Defense (THAAD) di Semenanjung Korea. Dalam pembahasan kepentingan, penulis perlu meninjau kebijakan yang dikeluarkan Amerika Serikat secara lebih mendalam. Oleh karena itu, tulisan "Asia-Pacific Security A Changing Role for the United States" dijadikan salah satu acuan kepustakaan ${ }^{17}$.

M. Najeri Al Syahrin pada tulisannya yang berjudul "Logika Dilema Keamanan Asia Timur dan Rasionalitas Pengembangan Senjata Nuklir Korea Utara" mengkaji tentang rasionalitas pengembangan senjata nuklir oleh Korea Utara yang dikaitkan dengan dilema keamanan di Asia Timur. Pembahasan meliputi deskripsi tentang reaksi dari security dilemma yang menciptakan dinamika arm races yang mengancam stabilitas keamanan kawasan. Dilema keamanan bagi Korea Utara ditandai dengan polaritas kekuatan, faktor historis dan konstruksi sosial amity dan enmity. Melalui metode studi kepustakaan, konsep teoritis security dilemma dijadikan landasan utama dalam memahami pengembangan senjata nuklir Korea Utara. Artikel ini menyimpulkan bahwa dilema keamanan di kawasan Asia Timur bersumber pada rasa takut dan ancaman akibat peningkatan kekuatan dan kapabilitas militer negara-negara lain di kawasan.

Tulisan Syahrin dibutuhkan untuk melihat kondisi sebenarnya yang terjadi di kawasan Asia Timur yang cenderung diwarnai ketegangan, sehingga Korea Utara bahkan mengembangkan Senjata nuklir di negaranya. Dengan membahas

\footnotetext{
${ }^{17}$ Rory Kinane dan Xenia Dormandy. Asia-Pacific Security A Changing Role for the United States. Chatham House report, London: The Royal Institute of International Affairs, Chatham House, 2014 : hlm. 44
} 
temuan yang didapat dari tulisan Syahrin, penulis berharap pembaca juga dapat memahami keadaan yang ada di Kawasan Semenanjung Korea. Keadaan tersebutlah yang akan mengantarkan keterlibatan Amerika Serikat dalam fenomena yang terjadi di Asia Timur ${ }^{18}$.

Secara keseluruhan, tulisan-tulisan yang dijadikan untuk referensi studi kepustakaan memiliki topik dan temuan yang berbeda-beda. Temuan tersebut dapat membantu penulis dalam menjelaskan kondisi di Asia Timur, khususnya kawasan Semenanjung Korea dan upaya pengembangan senjata nuklir yang dilakukan Korea Utara. Tulisan-tulisan tersebut juga dapat membantu menjelaskan keterlibatan Amerika Serikat di Asia Timur. Dengan hal ini, penulis juga akan mengatahui kepentingan yang hendak dicapai negara adikuasa tersebut dalam proses denuklirisasi di Semenanjung Korea.

\subsection{Kerangka Konsep}

\subsubsection{Status Quo vs Revisionist State}

Neoclassical-Realism merupakan perspektif yang menggabungkan teori realis klasik dan teori neo realis. Perspektif ini menjelaskan bahwa tindakan negara dapat dijelaskan dengan variabel sistemik (penyebaran kekuasaan di beberapa negara), variabel kognitif (persepsi terkait ancaman), dan variabel domestik (lembaga negara atau tokoh masyarakat) yang mempengaruhi kekuasaan.

Perspektif ini mengakui mengenai Balance of power ala neorealis tetapi perspektif ini melihat bahwa jika pemimpin suatu negara gagal melakukan

\footnotetext{
${ }^{18}$ M. Najeri Al Syahrin. "Logika Dilema Keamanan Asia Timur Dan Rasionalitas Pengembangan Senjata Nuklir Korea Utara.” Journal of International Studies, 2018: 117.
} 
penyeimbangan, maka akan mengakibatkan ketidakseimbangan sistem internasional. ${ }^{19}$

Dalam perspektif ini dikenal karakteristik negara yang terbagi atas Status Quo State dan Revisionist State. A.F.K. Organski dan Jacek Kugler menyatakan bahwa negara status quỏ sebagai pihak yang telah berpartisipasi dalam merancang 'aturan main' dan menerima manfaat dari aturan ini. Sedangkan negara revisionis menginginkan tempat baru untuk diri mereka sendiri dalam masyarakat intenasional. Negara-negara Revisionis menyatakan 'ketidakpuasan umum' terhadap posisi mereka dalam sistem sehingga mereka memiliki keinginan untuk menyusun kembali aturan yang digunakan dalam hubungan antar negara. Indikator yang paling jelas dalam mengidentifikasi negara revisionis ialah sudut pandang para pemimpin negara tersebut. Menurut Randall Schweller, negara revisionis menghargai apa yang mereka miliki saat ini, tetapi menginginkan lebih dari apa yang mereka miliki saat ini. Mereka akan cenderung menggunakan kekuatan militer untuk mengubah status quo. ${ }^{20}$

Kekuatan revisionis digambarkan sebagai negara yang sangat peduli terhadap prestise di atas semua pertimbangan, dan berusaha merombak sistem dan ketertiban internasional untuk keuntungannya sendiri. ${ }^{21}$ Ketidakpuasan memotivasi mereka untuk tidak memedulikan kekuatan dominan dan sekutu- sekutunya, sehingga negara revisionis cenderung mengabaikan kekuatan dominan dan lebih berfokus untuk membuat sistem berubah. Ketika kekuatan status quo

\footnotetext{
19 Chase O. Davidson. "Neoclassical Realism and The Colapse of the 1994 Agreed Framework". Iowa State University. 2008 : hlm. 76

${ }^{20}$ Alastair lain Johnston. International Security : "Is China a Status quo Power?". Vol 27. No.4. Harvard College dan MIT Press. Spring 2003 :

${ }^{21}$ Katherine Combes. POLIS Journal : "Between Revisionism and Status Quo : China in International Regimes: Chine's Behaviour in the Global Trade, Non Proliferation and Environmental Regimes". Vol. 6.University of Leeds. 2012 : 5
} 
lebih kuat dibandingkan negara revisionis, maka status sistem akan tetap stabil. Namun, jika kekuatan revisionis lebih kuat daripada pembela status quo, maka sistem pada akhirnya akan berubah.

Jika dilihat dari sistem internasional yang ada pada saat ini kita melihat bahwa kekuatan dominan dipegang oleh Amerika Serikat dan sekutunya. Sementara itu, Korea Utara hanyalah negara yang memiliki power yang berada di bawah negara-negara dominan. Korea Utara merasa tidak puas dengan posisinya di sistem karena dengan posisi yang lemah membuat Korea Utara lebih mudah terancam terutama dalam bidang keamanan. Oleh karena itu, Korea Utara ingin merubah sistem internasional yang telah ada dengan melakukan Pengembangan Nuklir di negaranya. Korea Utara menunjukan kepada dunia bahwa mereka juga memiliki senjata militer yang serius. Dari hal tersebutlah dapat dilihat bahwa Korea Utara berusaha menjadi Revisionist State.

\subsubsection{Range of State Interest}

Balance of interest merupakan konsep dari Neorealisme klasik yang berupaya merevisi kosep balance of power dan balance of threat. Konsep ini dapat bermakna ganda yaitu mencakup kepentingan negara di level unit maupun level sistemik. $^{22}$ Untuk menjelaskan konsep ini, Randall L. Schweller menegaskan adanya 'range' yang bisa menjelaskan posisi dan kepentingan suatu negara. Range ini diisi oleh negara yang mempertahankan status quo dan negara yang ingin perubahan atau revisi terhadap sistem. Range of State Interest dapat dilihat melalui tabel berikut ini:

\footnotetext{
${ }^{22}$ Randall L. Schweller. "Bandwagoning for Profit : Bringing the Revisionist State Back In". Hlm. 99
} 
Tabel 1.1

Range of State Interest

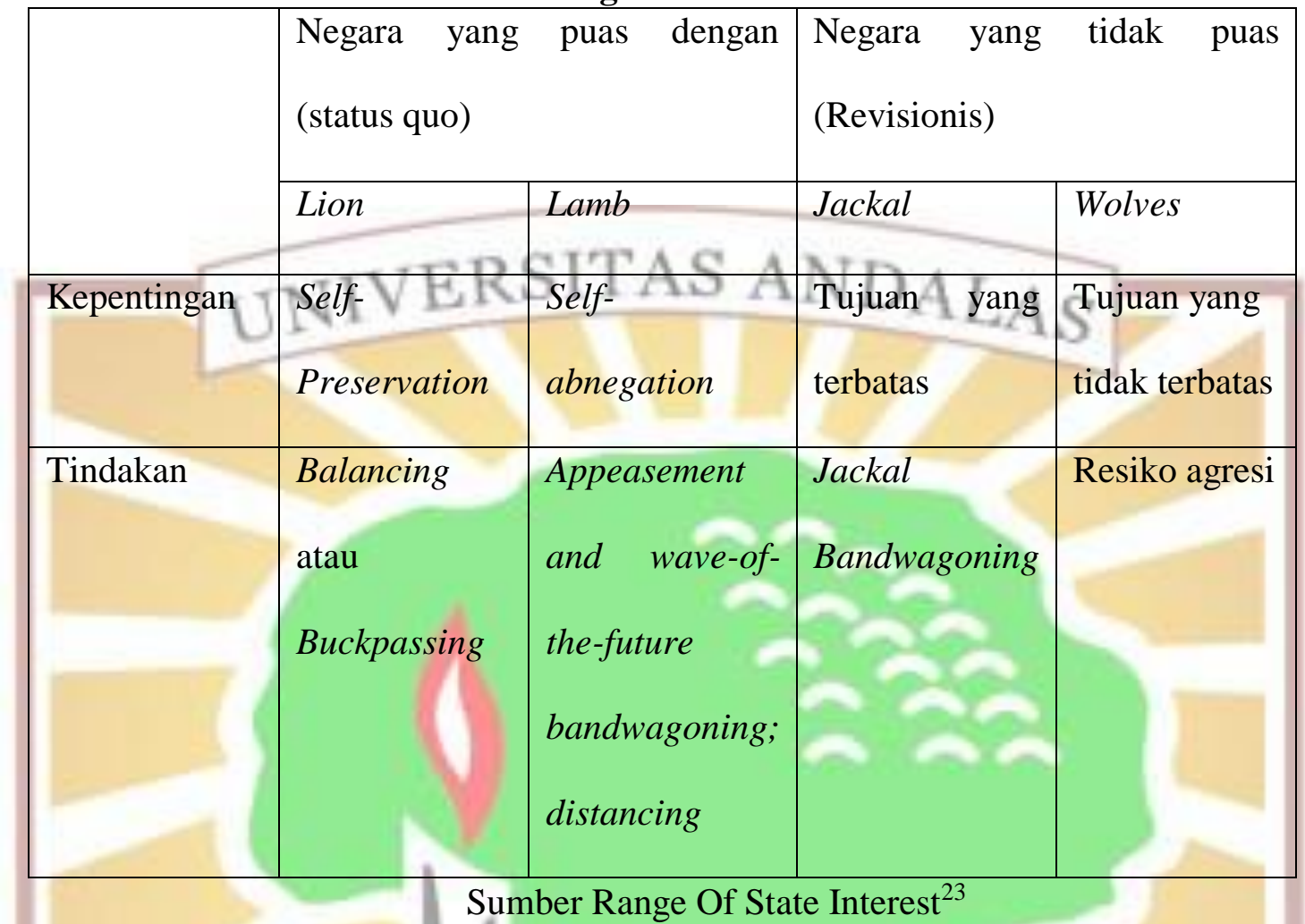

Dari tabel di atas dapat dilihat bahwa Lions merupakan negara yang akan membayar tinggi untuk melindungi apa yang mereka miliki. Sebagai pihak yang puas, negara ini akan mempertahankan kondisi yang telah ada (status quo). Oleh karena itu, negara Lions cenderung melakukan tindakan balancing atau buckpassing untuk mempertahankan posisi dan memaksimalkan keamanan mereka. ${ }^{24}$ Balancing merupakan tindakan penyeimbangan yang dilakukan oleh suatu negara terhadap negara lain yang berpotensi menciptakan ancaman agresi.

Sedangkan, Buck passing merupakan strategi suatu negara untuk mencegah

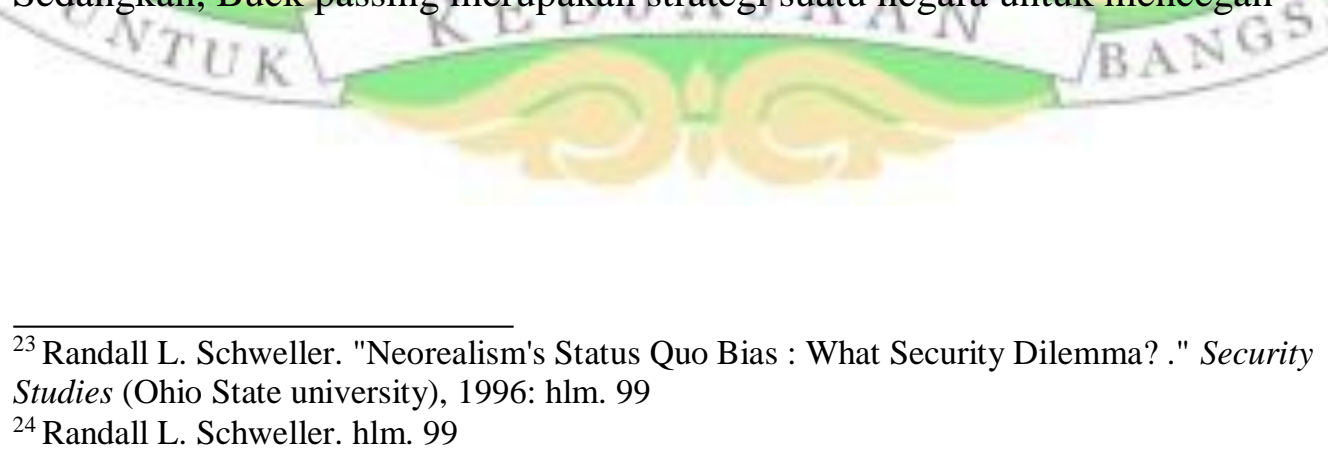


agressor dengan memanfaatkan negara lain sementara negara ini tetap mematuhi pedoman..$^{25}$

Sedangkan, lamb merupakan negara yang akan membayar rendah untuk pertahanan dan perluasan nilai mereka. Dalam sistem internasional, negara tipe ini merupakan negara yang memiliki kapabilitas lemah, baik dari segi politik, ekonomi, maupun pertahanan. Oleh karena itu, untuk menjaga dirinya tetap aman, negara ini hanya bertujuan untuk Self-abnegation..$^{26}$

Ketika suatu negara tidak bisa mengikuti dinamika keseimbangan atas polaritas kekuatan yang ada dalam sistem, maka negara tersebut rentan menjadi sasaran dominasi dan ekspansi negara lain. Oleh karena itu, pihak yang tidak puas dengan sistem internasional yang ada ialah negara-negara yang berada dalam range jackal dan wolves. Jackal merupakan negara yang akan membayar tinggi untuk mempertahankan apa yang mereka miliki, tetapi mereka juga akan biaya yang lebih besar lagi untuk memperluas nilai-nilai yang mereka miliki. ${ }^{27}$ Namun, negara dalam range ini cenderung tidak ingin mengambil resiko sehingga negara ini lebih sering mengikuti lion (negara pemimpin status quo) yang memiliki kekuatan besar. Oleh karena itu, negara dengan range Jackal sering memilih tindakan bandwagoning.

Walaupun Jackal dan wolves merupakan pihak yang tidak puas terhadap status quo, tetapi wolves merupakan pihak yang lebih ambisius untuk mencapai apa yang mereka idamkan. Oleh karena itu, negara dalam range ini cenderung bersedia mengambil resiko besar untuk memperbaiki kondisi mereka yang mereka

\footnotetext{
${ }^{25}$ Jhon Mearshimer. "The Tragedy of Great Power Politics". New York: W. Warton Company. Hlm. 157-158

${ }^{26}$ Randall L. Schweller.: "Bandwagoning for Profit : Bringing the State Back in". International Security. Vol. 19. No. 1. The MIT Press. 1994 : 101-102.

${ }^{27}$ Randall L. Schweller. "Bandwagoning for Profit : Bringing the State Back in”. Hlm. 103.
} 
anggap tidak dapat ditoleransi lagi. Tanpa rasa takut akan kehilangan, pihak ini akan berusaha mengejar ekspansi sembrono. ${ }^{28}$

Dalam sistem internasional, kita dapat melihat bahwa Amerika Serikat merupakan negara yang sudah memiliki kekuatan besar. Sementara itu, Korea Utara merupakan negara yầng berupaya untuk mengubah keadaan negaranya dalam sistem internasional. Pada penelitian ini penulis akan mengkategorikan Amerika Serikat sebagai lion. Sedangkan Korea Utara merupakan negara yang sedang menuju range wolves. Hal tersebut dikarenakan Korea Utara berusaha untuk berani untuk mengambil resiko untuk membuat negaranya diakui mempunyai posisi yang diperhitungkan di sistem internasional.

Dalam menganalisa Amerika Serikat, peneliti akan berfokus pada range Lion, yang mana negara dalam range ini memiliki tujuan primer untuk Self Preservation. Tujuan Self Preservation berarti negara berupaya untuk maksimalisasi keamanan (Security Maximizer) dan mempertahankan posisi (maintain position). Untuk mencapai maksimalisasi keamanan maka kepentingan yang harus dicapai ialah sebagai berikut :

1. Mempertahankan identitas independen

Setiap negara memiliki identitas masing-masing yang akan dipertahankan. Negara Lion sendiri biasanya memiliki identitas sebagai pemenang perang atau negara pemilik ekomomi dan keamanan yang terkuat. Identitas inilah yang akan dipertahankan oleh negara Lion.

\footnotetext{
${ }^{28}$ Randall L. Schweller. "Bandwagoning for Profit : Bringing the State Back in". Hlm. 103-104.
} 
2. Mempertahankan perdagangan positif ${ }^{29}$

Dalam memaksimalkan keamanannya, setiap negara juga perlu memperhatikan bidang ekonomi. Perhatian tersebut biasanya meliputi penguatan ekonomi domestik dan kegiatan ekspor-impor dengan negara lain

3. Meningkatkan integritas fungsional ${ }^{30}$

Negara harus bisa mengintegrasi kepentingan yang ingin dicapai oleh unitunit dalam domestiknya. Selain itu, negara juga perlu mempertimbangkan tekanan sistem internasional.

Sedangkan untuk mempertahankan posisi, maka negara ini harus mencapai kepentingan sebagai berikut :

1. Mempertahankan aliansi

Dalam mempertahankan posisi dalam sistem, suatu negara juga perlu mempertahankan aliansinya yang bisa memberikan keuntungan untuk negara tersebut. Hal ini juga berkaitan dengan prestise negara lion sebagai negara pelindung, terutama bagi aliansinya..

2. Mempertahankan prestise

Dengan menduduki posisi paling atas dalam sistem, maka negara lion akan mempertahankan posisi dirinya sebagai penjaga ketertiban dunia. Negara ini tentunya memiliki tanggung jawab untuk melindungi setiap aliansinya dari ancaman pihak lain.

${ }^{29}$ Randall L. Schweller. 'New Realist Research on Alliance : Refining, not Refuting, Walt'z Balancing Preposition”. American Political Science Review. Vol 91 : 4.1997 : hlm.928

${ }^{30}$ Randall L. Schweller. 'Neorealism's Status Quo Bias : What Security Dilemma?”. Hlm. 102 
3. Mencegah agresi (Frightened the Wolves) ${ }^{31}$

Sebagai pengelola sistem, negara lion akan menekan pihak manapun yang berpotensi untuk mengacaukan sistem yang telah didominasinya selama ini.

\subsection{Metode Penelitian ERSTTAS ANDAI}

\subsubsection{Jenis dan Pendekatan Penelitian}

Penelitian ini berjenis penelitian deskriptif yang bertujuan untuk menganalisa, mengidentifikasi, dan menjelaskan faktor dan indikator yang terkait dengan pertanyaan penelitian, serta untuk menjelaskan logika empiris yang diuraikan secara deduktif maupun induktif.

\subsubsection{Batasan Penelitian}

Penelitian ini terbatas pada periode 2009-2018. Hal ini dikarenakan peneliti berangkat dari adanya laporan fasilitas dan materi nuklir yang dimiliki Korea Utara pada Mei $2009^{32}$ serta pada 14 April 2009, Korea Utara menyatakan pengunduran dirinya dari forum Six Party Talks. ${ }^{33}$ Sedangkan, Donald Trump dan Kim Jong Un mengupayakan pembicaraan denuklirisasi secara bilateral pada tahun 2018. Untuk jangkauan masalah, penelitian ini hanya terbatas pada kepentingan Amerika Serikat dalam proses denuklirisasi Korea Utara dalam kurun waktu 2009-2018.

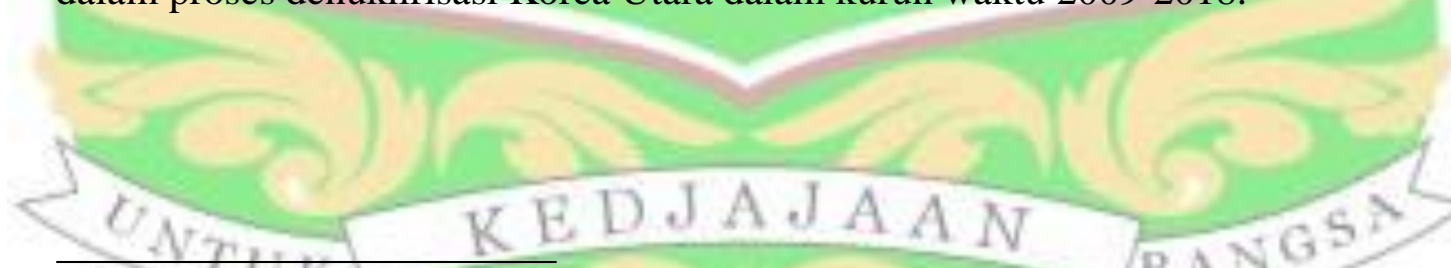

\footnotetext{
${ }^{31}$ Randall L. Schweller. "Bandwagoning for Profit : Bringing the Revisionist State Back In". HIm. 101

${ }^{32}$ Muhammad Nabil. "Diplomasi Multilateral Six Party Talks Dalam Proses Denuklirisasi Korea Utara Periode 2003-2009.”. Hlm 53

${ }^{33}$ Muhammad Nabil. Hlm 53
} 


\subsubsection{Unit Analisis, Unit Eksplanasi, dan Tingkat Analisis}

Peneliti memilih Amerika Serikat sebagai unit analisis karena peneliti akan mencoba menjelaskan kepentingan dari Amerika Serikat dalam keterlibatanya di konflik Semenanjung Korea Utara. Untuk unit eksplanasi yang mempengaruhi perilaku Amerika Serikat adalah nuklir Korea Utara dan hubungan Korea Utara dengan negara-negara di Asia Timur, karena negara-negara tersebut terlibat dalam konflik sehingga Amerika Serikat turun tangan. Kemudian, untuk tingkat analisis, peneliti memilih untuk berada pada level sistem internasional karena peneliti akan terfokus pada kepentingan Amerika Serikat dalam sistem internasional melalui tindakan yang dilakukan untuk merespon nuklir Korea Utara.

\subsubsection{Teknik Pengumpulan Data}

Peneliti menggunakan pengumpulan data dengan metode dokumentasi untuk mengumpulkan data-data terkait penelitian. Metode ini terfokus kepada informasi yang berasal dari catatan penting baik dari lembaga atau organisasi maupun dari perorangan. Teknik pengumpulan data yang akan digunakan penulis sendiri ialah Studi Kepustakaan yaitu dengan melakukan telaah terhadap literaturliteratur yang dilakukan dengan kategorisasi dan klarifikasi bahan-bahan yang terkait dengan masalah yang diangkat dalam penelitian ini dengan teknik pengumpulan data dokumentasi yang diambil dari buku-buku, jurnal-jurnal, media massa yaitu mengakses situs-situs internet. Dengan demikian, data dan informasi yang digunakan dalam penelitian ini bersifat sekunder.

Selain dokumen yang telah didapatkan, peneliti berencana untuk mengumpulkan literatur yang dapat mendukung penelitian ini. Peneliti juga menggunakan media internet untuk mencari informasi dan data-data yang 
diperlukan dengan kata kunci pencarian Kepentingan nasional, Kebijakan Amerika Serikat, dan Denuklirisasi Korea Utara. Untuk situs internet yang akan dikunjungi, peneliti berencana untuk mengunjungi situs kementrian luar negeri Amerika Serikat, dokumern National Security Strategy Amerika Serikat, web resmi PBB, dan beberapa situs terpercaya lainnya yang data dan informasinya dapat mendukung mengenai kepentingan Amerika Serikat dalam proses Reunifikas Korea.

\subsubsection{Teknik Analisis Data Penelitian}

Langkah-langkah analisis data menurut Miles dan Huberman adalah sebagai berikut $^{34}$ :

\section{Reduksi Data}

Data-data yang telah disusun secara sistematis akan di reduksi, atau diabstraksikan secara terperinci. Reduksi data dimulai sejak peneliti memfokuskan wilayah penelitian. Peneliti akan memfokuskan beberapa data yang terkumpul dalam suatu sub bahasan. Bab II hanya akan berisi data mengenai nuklir Korea Utara dan dinamika hubungan negara-negara Asia Timur dengan Korea Utara. Data-data mengenai tindakan Amerika Serikat akan dipilah dan dikumpulkan dalam bab III. Begitu pula pada bab IV, hanya akan berisi data-data pilahan yang medukung kepentingan Amerika Serikat dalam proses denuklurisasi Korea Utara.

\section{Penyajian Data}

Data yang telah dirincikan dibatasi dengan batasan yang jelas. Data tersebut disajikan secara sistematis. Penyajian data juga diperoleh dari berbagai jenis, jaringan kerja, keterkaitan kegiatan atau tabel. Misalnya, dari grafik yang

\footnotetext{
${ }^{34}$ Sugiyono. Metode Penelitian Pendidikan, Pendekatan Kuantitatif, Kualitatif, dan R\&D. Bandung: Alfabeta, 2012: 247
} 
menjelaskan kemampuan nuklir Amerika Serikat dari rentang waktu 2009-2018 cenderung meningkat, grafik mengenai kemampuan nuklir Korea Utara juga meningkat, dari kedua tabel tersebut peneliti berusaha menganalisis pola atau kecenderungan yang saling terkait dalam dua grafik tersebut. Dapat disimpulkan bahwa kemampuan nuklir dari kedua negara tersebut sama-sama cenderung meningkat dari tahun ke tahun.

\section{Penarikan Kesimpulan}

Setelah data-data di analisis, maka akan ada kesimpulan yang dapat di ambil dari penelitian yang dilakukan. Peneliti berusaha untuk menganalisis dan mencari pola, tema, hubungan persamaan, hal-hal yang sering timbul, hipotesis dan sebagainya yang dituangkan dalam kesimpulan tentatif. Dari data-data yang telah dikumpulkan, peneliti dapat mengambil kesimpulan sementara bahwa Amerika Serikat ikut terlibat aktif dalam proses denuklirisasi Semenanjung Korea karena memiliki kepentingan untuk menjaga dominasi nya di Asia Timur dan dunia internasional. Hal tersebut dikarenakan Asia Timur sendiri di apit oleh beberapa negara super power seperti Amerika Serikat sendiri, Rusia, dan negara yang dipercaya menjadi kekuatan baru di Asia yaitu Tiongkok.

Untuk mempertahankan status quo mengenai eksistensi dan pengaruhnya di dunia internasional, maka Amerika Serikat harus ikut berperan dalam fenomena yang terjadi di lingkungan internasional, khususnya dalam penjagaan stabilitas

sistem internasional. Amerika Serikat juga mengupayakan perjanjian damai antara

Korea Selatan dan Korea Utara karena Amerika Serikat memiliki kepentingan untuk membuat Korea Utara memusnahkan senjata nuklirnya, dengan begitu ancaman terhadap keamanan nasionalnya akan berkurang. 


\subsection{Sistematika Penulisan}

\section{Bab I Pendahuluan}

Dalam bab ini akan membahas mengenai latar belakang permasalahan yang diformulasikan ke dalam pertanyaan penelitian serta pengajuan hipotesa yang akan dibuktikan, dengan disertai kerangka pemikiran, model analisis dan operasionalisasi konsep.

Bab II Nuklir Korea Utara dan Dinamika Politik Kawasan Asia Timur

Bab ini akan menjelaskan mengenai Korea Utara dalam dinamika Politik Kawasan Asia Timur, khususnya hubungan Korea Utara dan Korea Selatan pasca terjadinya Perang Korea sampai pada tahun 2018 serta hubungan Korea Utara dengan Jepang dan Tiongkok. Bab ini juga akan menjelaskan pengaruh nuklir Korea Utara dengan politik internasional.

Bab III Upaya Amerika Serikat dalam Proses Denuklirisasi Korea Utara

Bab ini akan menggambarkan mengenai upaya yang dilakukan Amerika Serikat dalam keterlibatannya untuk proses Denuklirisasi Semenanjung Korea, baik yang dilakukan secara koersif maupun diplomatis (pembicaraan bilateral dan mendukung reunifikasi Korea Utara-Korea Selatan)

Bab IV $U$ Kepentingan Amerika Serikat dalam Proses Denuklirisasi Korea Utara 
Bab ini membahas mengenai analisa penulis terkait posisi Amerika Serikat di system internasional dan kepentingannya Amerika Serikat yang terus mengupayakan terciptanya denuklirisasi di Semenanjung Korea.

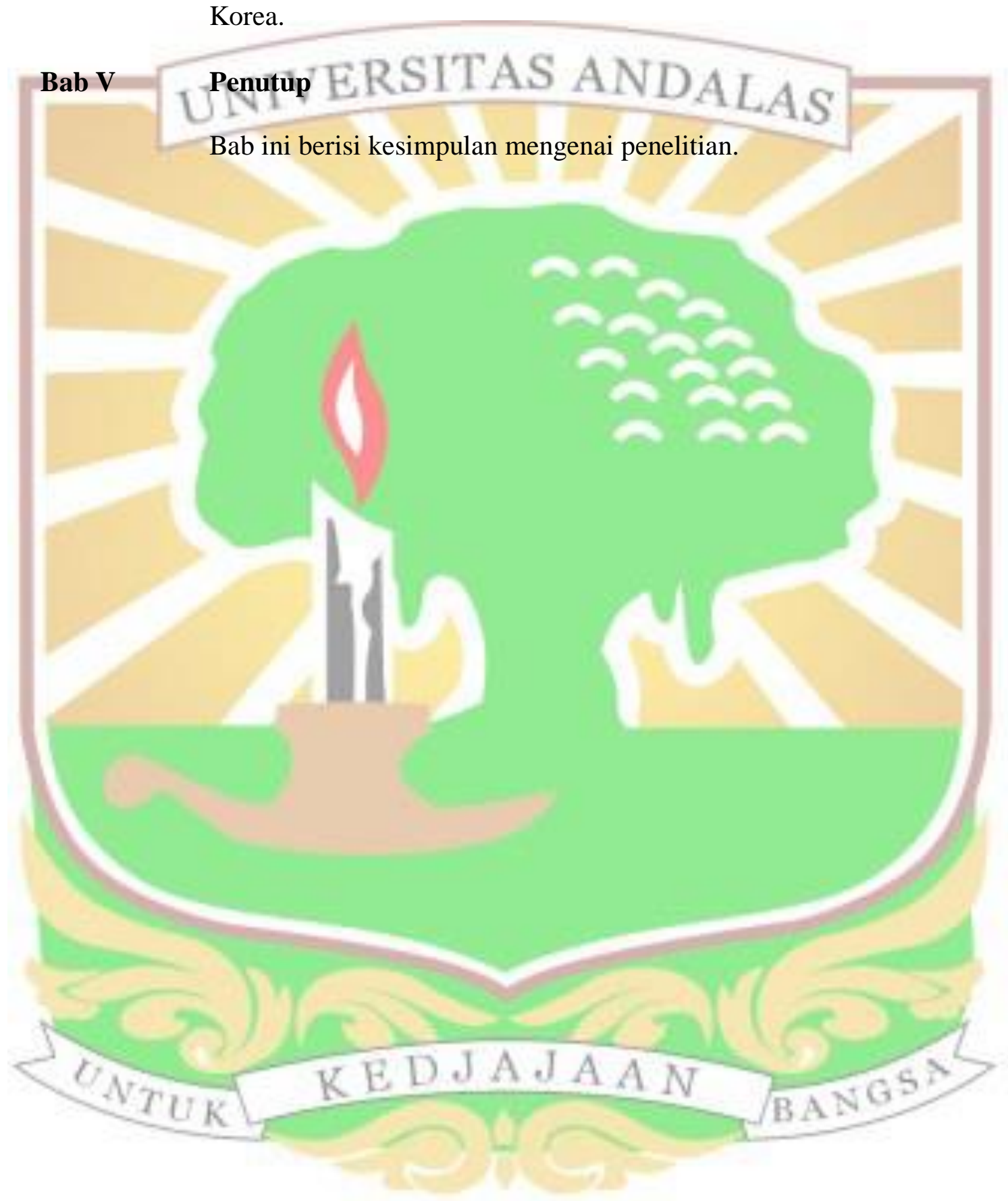




\section{BAB II}

NUKLIR KOREA UTARA DAN DINAMIKA POLITIK KAWASAN ASIA TIMUR

Saat membahâs isu nuklir Korea Utara, maka tidak akan terlepas dengan pembahasan mengenai dinamika hubungan Korea Utara dengan negara-negara di kawasannya. Oleh karena itu, bab ini membahas tentang pengembangan senjata nuklir yang meliputi motif dan uji coba senjata nuklir Korea Utara. Kemudian, bab ini juga akan membahas mengenai dinamika hubungan antara Korea Utara dengan negara-negara di Asia Timur.

\subsection{Pengembangan Senjata Nuklir Korea Utara}

Program nuklir Korea Utara berawal sejak terjadinya Perang Dingin.

Setelah Korea di pisahkan, Kim Il Sung (pemimpin Korea Utara pada saat itu) dibantu oleh Pemimpin Uni Soviet, Stalin, dari segi persenjataan untuk melawan orang-orang di Korea bagian Selatan. Dengan bantuan tersebut, Korea Utara bergerak untuk menyerang hingga perang berakhir pada tahun 1953. Perang ini diakhiri dengan adanya gencatan senjata dan zona demiliterisasi. ${ }^{35}$ Dikarenakan perang yang belum diakhiri secara pasti, Kim Il Sung merasa perlu untuk memiliki nuklir untuk mengakhiri konflik. Uni Soviet kemudian menawarkan diri untuk membantu Korea Utara menjadi negara yang memiliki program pengembangan nuklir.

${ }^{35}$ M. Najeri Al Syahrin "Logika Dilema Keamanan Asia Timur dan Rasionalitas Pengembangan Senjata Nuklir Korea Utara". Intermestic : Journal of International Studies. Vol.2 no.2 . 2018 : 131 
Uni Soviet melakukan serangkaian penelitian geologi untuk biji uranium di Korea Utara. ${ }^{36}$ Cadangan uranium pada saat itu diperkirakan mencapai 26 juta ton. Pada tahun 1956, kemudian ditandatangani Perjanjian Partisipasi Kerjasama damai penggunaan nuklir antar kedua negara. Pada tahun 1963, Korea Utara merupakan negara yang menolak Perjanjian Pelarangan Senjata Nuklir yang digagas oleh Presiden Amerika pada saat itu, John F. Kennedy. Setelah Tiongkok berhasil melakukan uji coba nuklir pada 1964, Korea Utara meminta bantuan pada Tiongkok. Sayangnya Tiongkok tidak meresepon dengan tanggapan baik sehingga Korea Utara mempererat kerjasamanya dengan Moskow. ${ }^{37}$ Dua tahun kemudian, Korea Utara mulai memiliki reaktor nuklir pertamanya.

Korea Utara memiliki pemahaman bahwa negaranya bisa berlindung di balik program nuklirnya hingga 1990-an bahkan sampai Uni Soviet jatuh. Kemudian, pada tahun 1992, Korea Utara menerima perjanjian pengawasan yang disyaratkan NPT (Non Proliferation Treaty) untuk menerima inspeksi dari IAEA (International Atonomic Energy Agency). ${ }^{38}$ Sesuai dengan perjanjian yang telah diterima, IAEA akan melakukan inspeksi enam kali ke Korea Utara. Namun, Korea Utara beberapa kali menolak inspeksi yang dilakukan.

Menteri Luar Negeri Amerika Serikat, James A. Kelly, menyatakan bahwa Korea Utara telah melakukan pengayaan uranium dalam program nuklirnya pada tahun 2002. Korea Utara pun tidak menyangkal penyataan tersebut. Negara yang awalnya tergabung dalam perjanjian NPT akhirnya mengeluarkan diri pada 2003.

Dengan adanya pelatihan dari Moskow, Korea Utara berhasil memperoleh

\footnotetext{
${ }^{36}$ Febby Siskawati. "Pengaruh Kebijakan Pertahanan Korea Utara terhadap Tatanan Ekonomi di Asia Timur". Yogyakarta : Universitas Muhammadiyah Yogyakarta . 2018 : hlm 2

${ }^{37}$ Febby Siskawati. hlm 2

${ }^{38}$ Alfina Farmanita Wicahyani. "Dampak Pengembangan Nuklir Korea Utara terhadap Kompleksitas Keamanan Regional Asia Timur”Depok : Universitas Indonesia. 2010 : hlm. 30
} 
plutonium untuk terus mengembangkan senjata nuklir. Nuklir dipercaya bisa melawan serangan dari musuh Korea Utara, khususnya Amerika Serikat dan mengurangi ketergantungan Korea Utara terhadap negara lain. Motif dan uji coba nuklir Korea Utara akan dijelaskan di sub bagian berikut ini.

\subsubsection{Motif Pengembangan Senjata Nuklir Korea Utara}

Korea Utara merupakan negara yang secara sepihak menyatakan bahwa negaranya percaya dan bergantung pada kekuatan sendiri. Hal ini lebih dikenal dengan ideologi juche. Korea utara juga memiliki sistem politik yang didasarkan pada prinsip sentralitas. ${ }^{39}$ Bukan hanya itu, konstitusi negara ini pun menerangkan bahwa Partai Buruh Korea merupakan tingkat kekuasaan tertinggi. Hal ini membuat pemimpin Korea Utara tetap memimpin untuk waktu yang lama.

Karakter Korea Utara pun merupakan cerminan dari karakter idiosinkratik dari para pemimpinnya yang cenderung agresif, terutama dalam pengembangan nuklir.

Mayoritas literatur menyajikan dua argumen dasar mengenai motif Korea Utara dalam mengembangkan senjata nuklirnya. Argumen pertama yaitu 'doves' yang mengungkapkan bahwa terancamnya Korea Utara dari segi militer, politik, dan ekonomi membuat Korea Utara tetap bersikukuh untuk mempertahankan pengembangan senjata nuklirnya. ${ }^{40}$ Singkatnya, argumen pertama ini melihat bahwa aliansi Amerika Serikat dan Korea Selatan yang bekerjasama terutama di bidang militer, membuat Korea Utara merasa terancam. Hal tersebut dikarenakan

Korea Utara merupakan 'musuh' dari Korea selatan dalam konflik Semenanjung

\footnotetext{
${ }^{39}$ Irwindi Famega. Pendekatan Ideologi dalam Hubungan antara Korea Selatan dan Korea Utara (Studi Kasus: Dinamika dalam Proses reunifikasi Periode Pemerintahan Moon Jae In). Medan: Universitas Sumatera Utara, 2018 : hlm. 53

${ }^{40}$ Nicholas D Anderson. hlm. 2
} 
Korea. Selain itu, baik Korea Selatan maupun Amerika Serikat juga memiliki ideologi yang bertolak belakang dengan Korea Utara.

Korea Utara menggunakan pengembangan senjata nuklir untuk mendapatkan bantuan ekonomi dari negara lain. Hal ini seperti saat Korea Utara berjanji akan menghentikan program nuklirnya atau 1 izin inspeksi IAEA (International Atonomic Energy Agency) dengan imbalan mengirimkan bantuan bahan bakar dan makanan dari Tiongkok dan Korea Selatan. Selain itu, Korea Utara juga menggunakan senjata nuklirnya untuk keluar dari sanksi keuangan atau sanksi embargo, serta untuk mendapatkan keuntungan ekonomi lainnya.

Berbeda dengan argumen pertama, argumen 'Hawks' cenderung menitikberatkan bahwa psikologis, insentif politik domestik, dan motif revisionis merupakan pendorong utama bagi pengembangan senjata nuklir negara tersebut. ${ }^{41}$ Argumen ini berkaitan dengan ideologi Juche yang dianut oleh Korea Utara. Ideologi ini menyatakan bahwa yang menentukan takdir dari suatu negara ialah negara itu sendiri. Bagi Korea Utara, tugas untuk mentransformasi ide dan kekuatan juche ialah dengan melakukan revolusi. Oleh karena itu, Korea Utara cenderung ingin mengubah keadaan dengan cara mengembangkan senjata nuklir di negaranya. Hal ini terkait dengan sikap komunitas internasional yang cenderung mengasingkan dan menekan Korea Utara dalam sistem internasional.

Oleh karena itu, Pada tahun 1986 Korea Utara berambisi untuk mengembangkan senjata nuklir. Ambisi tersebut diwujudkan dengan pengembangan reaktor nuklir dengan kekuatan 5 megawatt di Yongbyon, Korea Utara. Kemudian pada tahun 1993, Korea Utara mengumumkan bahwa negara tersebut menarik diri dari NPT

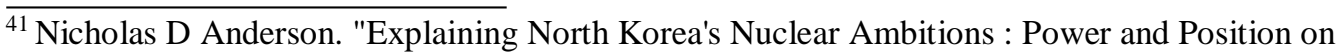
the Korean Peninsula." Australian Journal of International Affairs , 2017 : hlm. 5
} 
(Non Proliferation Treaty). ${ }^{42}$ Menanggapi hal tersebut, Amerika Serikat mendorong Korea Utara untuk menandatangani kesepakatan untuk menutup Pengembangan Reaktor Nuklir Yongbyon. Amerika Serikat pun memberikan reaktor nuklir yang dapat menghasilkan listrik sebagai ganti dari penutupan program. Namun, pada tahun 2002, Korea Utara malah mengumumkan bahwa negara tersebut memiliki fasilitas untuk menghasilkan uranium. Selanjutnya, pada tahun 2003 Korea Utara resmi menarik diri dari NPT. ${ }^{43}$ Beberapa bulan kemudian Korea Utara bersedia membuka diri untuk melakukan perundingan yang melibatkan enam negara atau yang dikenal dengan Six Party Talks. Walaupun pada Februari 2005, Korea Utara mengklaim bahwa pengembangan senjata nuklir masih dilanjutkan. ${ }^{44}$

\subsubsection{Uji Coba Nuklir Korea Utara}

Perundingan Six Party Talks mengalami proses negosiasi yang kurang baik untuk menghentikan nuklir Korea Utara sehingga pada tahun 2005, dibawah pimpinan Kim Jong Il, negara tersebut mengumumkan telah memiliki senjata nuklir. Senjata tersebut di uji cobakan pertama kali pada tahun 2006. Pada tahun 2008 pun Korea Utara melakukan percobaan penembakkan peluru kendali jarak pendek ke arah Laut Jepang. ${ }^{45}$ Pengembangan senjata nuklir tersebut terus

${ }^{42}$ Muhammad Nabil. hlm. 40

${ }^{43}$ Andi Purwono dan Ahmad Saifuddin Zuhri. "Peran Nuklir Korut Sebagai Instrumen Diplomasi Politik Internasional"dalam Jurnal Ilmu Politik Hubungan Internasional . Vol. 7, No. 2.Unwahas, 2010. Hlm. 5

${ }^{44}$ Jonathan D. Pollack. No Exit: North Korea, Nuclear Weapons and International Security. Washington DC: Routledge, 2010. Hlm. 13

${ }^{45}$ Irwindi Famega. Pendekatan Ideologi dalam Hubungan antara Korea Selatan dan Korea Utara (Studi Kasus: Dinamika dalam Proses reunifikasi Periode Pemerintahan Moon Jae In). Medan: Universitas Sumatera Utara, $2018: 65$ 
berlanjut dan di uji coba kembali pada tahun 2009. ${ }^{46}$ Korea Utara pun memperingatkan Korea Selatan untuk tidak melakukan provokasi, termasuk mengadakan latihan militer dengan peluru tajam di batas laut yang dipersengketakan. Pada tahun 2011 Korea Utara diketahui masih menggunakan reaktor air ringan di Yongbyon. Tindakan ini pun menghasilkan ketegangan antara pihak yang berkonflik dan juga Amerika Serikat.

Setelah rezim Kim Jong Il berpindah ke Kim Jong Un, Korea Utara tidak berhenti melakukan pengembangan senjata nuklir sehingga memperoleh sanksi dari PBB. Tahun 2012, Korea Utara meluncurkan rudal jarak jauh yang disusul uji coba senjata pada tahun 2013. Bahkan, pada tahun 2015 Korea Utara mengumumkan telah mampu menciptakan Bom Hidrogen, walaupun belum bisa dipastikan kebenarannya. ${ }^{47}$ Pada 6 Januari 2016, Korea Utara pun melakukan uji coba senjata nuklir dengan meledakkan bom hidrogen. Adapun kemampuan nuklir Korea Utara berdasarkan beberapa kali uji coba adalah sebagai berikut :

\section{Tabel 2.1}

Tabel Kemampuan Uji Coba Nuklir Korea Utara

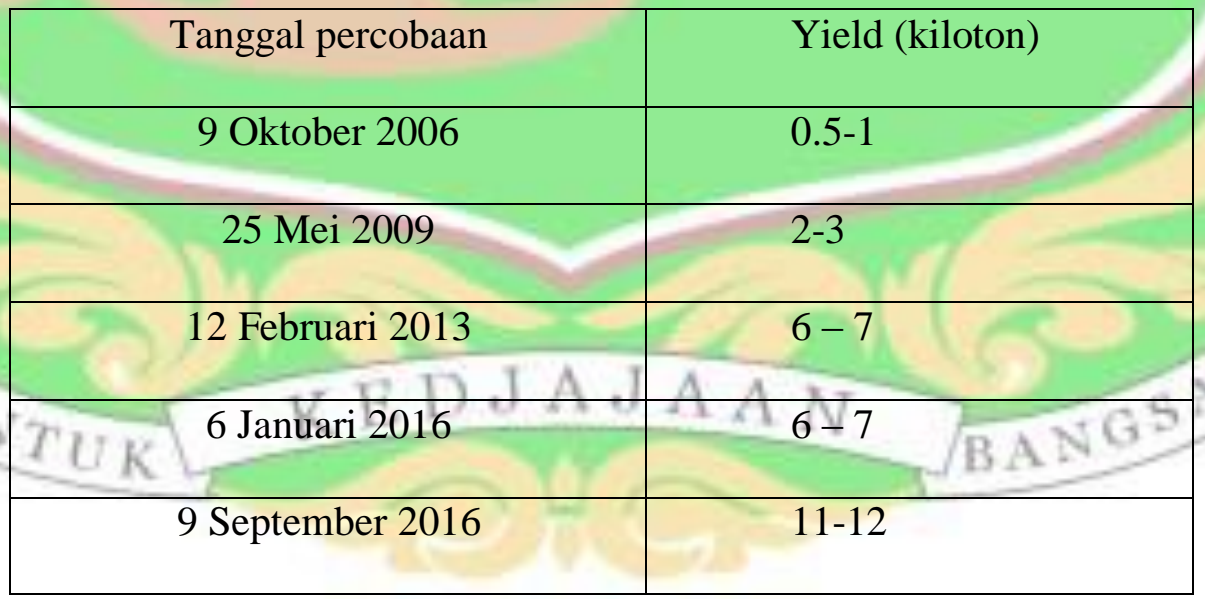

\footnotetext{
${ }^{46}$ Rahmalia Ayu Widayanti. Instalasi Sistem pertahanan Rudal Terminal High Altitude Area Defense (THAAD) Amerika Serikat di Korea Selatan. Jember: Universitas Jember, 2018 : hlm. 38

${ }^{47}$ Rahmalia Ayu Widayanti. Hlm. 39
} 


\begin{tabular}{|c|c|}
\hline 3 September 2017 & $140-250$ \\
\hline \multicolumn{2}{|c|}{ Sumber: Comprehensive Nuclear Test Ban Treaty Organization, US } \\
\hline
\end{tabular}

Geological Survey, and others. $(2017)^{48}$ North Korea Nuclear Tests $(2018)^{49}$

Uji coba nuklir dimaknai sebagai alat untuk memperkuat posisi Korea Utara di sistem internasional. Hal ini juga berkaitan dengan realitas isolasi keterlibatan
ekonomi dan politik akibat Perang Korea. Di bawah kepemimpinan Kim Jon Un,
menghasilkan perhatian komunitas internasional dan upaya untuk
mendapatkan lebih banyak keuntungan dan kekuatan dalam posisinya.

\footnotetext{
${ }^{48}$ TetsuoMurooka and Hiroyasu Akutsu. "The Korean Peninsula: North Korea's Growing Nuclear and Missile Threat and South Korea's Anguish",2017,hlm. 107

${ }^{49}$ Hans M. Kristensen dan Robert S. Norris. "North Korean Nuclear Capabilities, 2018". Bulletin of the Atomic Scientists. Vol. 74. No. 1. Routledge. 2018 : hlm. 45
} 


\subsection{Dinamika Hubungan Korea Utara dengan Negara-Negara kawasan Asia}

\section{Timur}

Korea Utara yang memiliki nama resmi Democratic People's Republic of Korea merupakan bagian dari kawasan Asia Timur yang meliputi sebagian utara Semenanjung Korea. Zona demiliterisasi menjadi pembatas antara negara ini dengan Korea Selatan. Sedangkan, Sungai Amnok dan Sungai Tumen menjadi perbatasan antara Korea Utara dan Tiongkok. berikut merupakan gambar posisi Korea Utara pada peta kawasan Asia Timur :

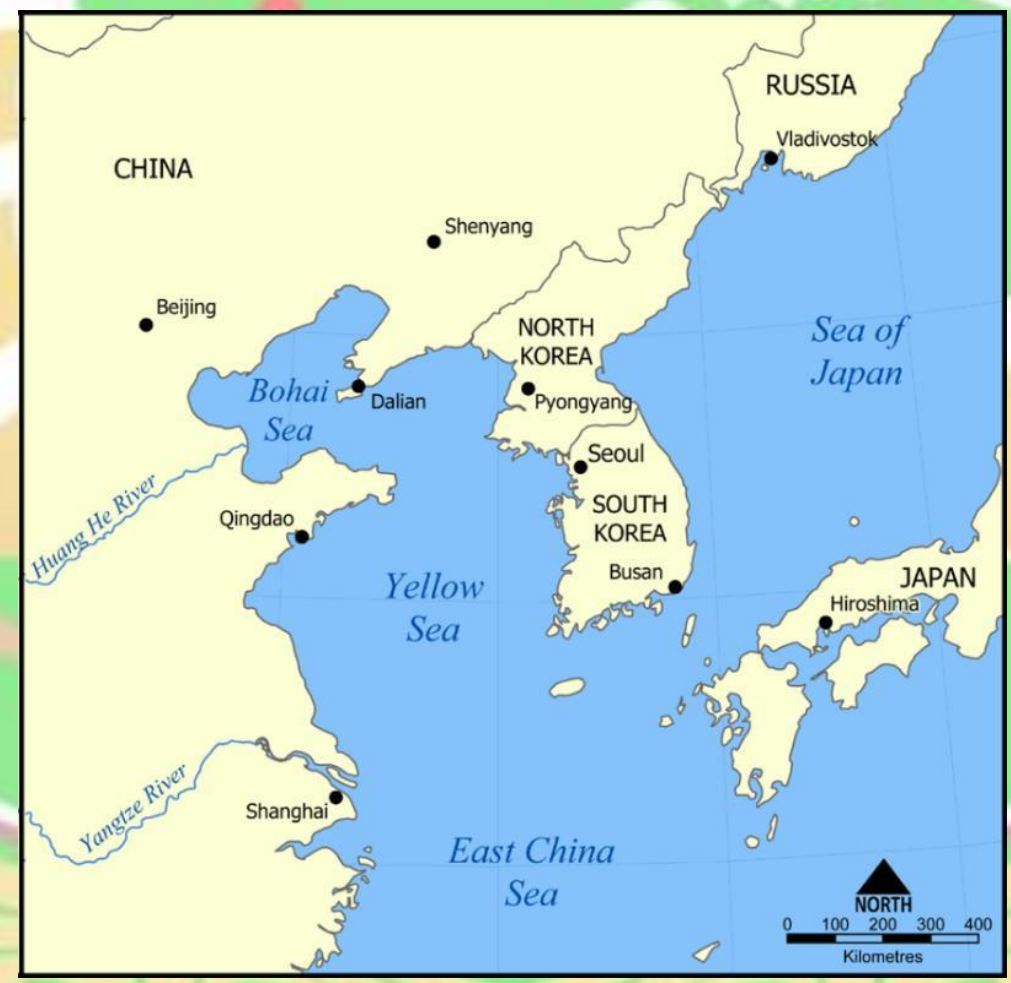

Gambar 2.1

\section{Gambar Peta Asia Timur}

Sumber : Peta Asia Timur dan Laut Kuning

Seperti yang telah disebutkan sebelumnya, Korea Utara merupakan negara yang masih lemah dalam kondisi ekonomi. Selain itu, negara ini juga cenderung

${ }^{50}$ Diakses dari https://www.google.com/search?q=peta+bohai+sea\&safe=strict\&client=ms pada 15 Oktober 2019 
diisolasi dari komunitas internasional akibat Perang Korea dan ideologinya. Oleh karena itu, Korea Utara berusaha untuk mengembangkan senjata nuklirnya yang bisa mengubah posisi dan pola hubungannya dengan negara lain, khususnya negaranegara Asia timur. ${ }^{51}$ Di kawasan Asia Timur, Korea Utara memiliki hubungan persahabatan maupưn permusuhan. Namun, pola ini terus mengalami pasang surut dari tahun ketahunnya.

Dinamika hubungan Korea Utara dengan negara-negara di Asia Timur tentunya sangat dipengaruhi oleh keberadaan nuklir Korea Utara. Tindakan agresif Korea Utara membuat krisis di Semenanjung Korea semakin mengalami ketegangan. Dengan potensi yang dimiliki Korea Utara saat ini, negara ini lebih memilih untuk melakukan tindakan yang militeristik daripada bentuk diplomasi.

Hal ini membuat negara-negara lain di kawasan Asia Timur perlu membuat langkah serius untuk menanggapi tindakan Korea Utara. Berikut merupakan dinamika hubungan antara Korea Utara dengan negara-negara di Asia Timur.

\subsubsection{Dinamika Hubungan Korea Utara dan Korea Selatan}

Perang Korea yang berakhir pada 1950-an, membuat hubungan kedua negara menjadi tidak baik. Namun hubungan diplomatik informal antara kedua negara mulai membaik pada tahun $1971 .^{52}$ Kedua pemerintah menyatakan bahwa penyatuan kembali kedua negara akan dilakukan secara independen tanpa campur tangan asing dengan cara damai, serta melalui kesatuan nasional besar. Tiga prinsip ini tetap dipegang selama tiga dekade berikutnya. ${ }^{53}$ Terdapat beberapa

\footnotetext{
${ }^{51}$ M. Najeri Al Syahrin. Hlm. 131

${ }^{52}$ Angga Aditama P. hlm. 5

${ }^{53}$ Irwindi Famega. Pendekatan Ideologi dalam Hubungan antara Korea Selatan dan Korea Utara (Studi Kasus: Dinamika dalam Proses reunifikasi Periode Pemerintahan Moon Jae In). Medan: Universitas Sumatera Utara, 2018 : 73
} 
sknario reunifikasi antara Korea Selatan dan Korea Utara, yaitu Gradual (secara damai), Status Quo, Collapse (Keruntuhan Korea Utara), dan perang. ${ }^{54}$

Pada tahun 1988, saat diselenggarakannya olimpiade di kedua negara, hubungan kedua negara kembali mengalami ketegangan karena Korea Utara menginginkan negaranya yang menjadi tuan rumah olimpiade olahraga tersebut sedangkan Korea selatan tidak mengizinkan Korea Utara untuk bergabung. ${ }^{55}$ Pada tahun 1991 ditandatangani sebuah perjanjian Agreement on Reconciliation, Nonaggression and Exchanges and Cooperation between The South and The North yang isinya merupakan adanya niat untuk reunifikasi kedua negara. ${ }^{56}$ Dengan semakin membaiknya hubungan antara kedua negara, maka pada 1992 ditandatangani kesepakatan Joint Declaration of the Denuclearization of the Korean Peninsula.

Selanjutnya, olimpiade Asian Games yang diselenggarakan di Busan pada 2002 memunculkan kesempatan adanya perbaikan hubungan antara Korea Selatan dan Korea Utara. Kerjasama di bidang olahraga antara kedua negara pun semakin berkembang sejak diberlakukannya Sunshine Policy oleh Korea Selatan pada masa pemerintahan Kim Dae Jung pada 1998. Namun, hubungan kedua negara tidak secara tetap diwarnai kedekatan. Hubungan kedua negara cenderung mengalami pasang surut terutama karena perbedaan pandangan terhadap nuklir dan hubungan antara pemimpin kedua negara. ${ }^{57}$ Pada tahun 2008 , meskipun

${ }^{54}$ Colonel David Coghlan. "Prospect from Korean Unification." Strategy Research Project, 2008:Hlm.13-15

${ }^{55}$ Vina Rosyada. Strategi Perdamaian di Semenanjung Korea . Surabaya: Universitas Islam Negeri Sunan Ampel Surabaya, 2019: 48

${ }^{56}$ Angga Aditama P. Hlm. 6

${ }^{57}$ Angga Aditama P. hlm. 7 
Korea Utara sedang mengalami krisis pangan, tetapi Kim Jong Il tetap membeli senjata dengan harga puluhan juta rupiah untuk militernya.

Meskipun kebijakan sunshine Policy yang dilakukan Korea Selatan dinilai hampir memberi kesempatan kedua negara untuk bersatu kembali. Namun, Korea Utara tetap melakukan uji coba nuklir pada Mei 2009. Dalam menaanggapi agresifitas Korea Utara maka pada bulan November 2010, Korea Selatan melakukan latihan perang bersama dengan Amerika Serikat yang membuat hubungannya dengan Korea Utara menjadi tegang kembali. Selanjutnya, Chong Wook Chung sebagai Wakil Ketua Komite Khusus Reunifikasi menyatakan bahwa reunifikasi antara dua negara masih sulit untuk dicapai karena Korea Utara sendiri menginginkan Amerika Serikat tidak lagi mencampuri urusan Korea Selatan. Selain itu, sulit untuk mencapai penyatuan kembali jika gap antara perekonomian Korea Utara dan Korea selatan sangat jauh berbeda. ${ }^{58}$ Bukan hanya itu, Korea Selatan juga menghentikan bantuan pangan kepada Korea Utara. ${ }^{59}$

Pada tahun 2013, Park Geun Hye menggunakan pendekatan Trust Politic yang meliputi Strong defense, trust diplomacy, dan Korean Peninsula trust policy. ${ }^{60}$ Namun, tindakan Park berdampak baik karena Korea Utara pun semakin gencar melakukan uji coba nuklir pada 2016 yang membuat negaranya dan Korea Selatan jauh. Namun, sejak terpilihnya Moon Jae In pada tahun 2017, upaya reunifikasi Korea pun mendapatkan peluang karena Món Jae In dianggap sebagai pemimpin yang pro dengan kebijakan sunshine policy pada masa lalu. ${ }^{61}$ Moon Jae

\footnotetext{
${ }^{58}$ Irwindi Famega. 76

${ }^{59}$ R. G. S. Moren. "Reaksi Korea Utara terhadap Kebijakan Korea Selatan Memberhentikan Bantuan terhadap Korea Utara (2008-2011)." 2011:Hlm. 6

${ }^{60}$ Elpeni Fitrah. "Analisis Pendekatan Trust Politic Korea Selatan dalam Penyelesaian Hambatan Reunifikasi di Semenanjung Korea." Insignia Journal of International Relations 5 (2018): Hlm.86

${ }^{61}$ Irwindi Famega. Hlm. 81
} 
In menyayangkan pemerintahan sejak Lee Myung Bak tidak mempertahankan kebijakan ini dan cenderung memperkeruh hubungan antara Korea Selatan dan Korea Utara. Bagi Moon, pemerintahan sebelumnya memutus hubungan dengan Korea Utara dan hanya mendesak denuklirisasi Korea Utara tanpa ada upaya perbaikan hubunngān. Moon Jae In percaya jika Korea Selatan dapat menjaga hubungan baik dengan Korea Utara maka hal tersebut akan menjadi dasar untuk reunifikasi kedua negara.

Pada 27 April 2018, masyarakat internasional dikejutkan dengan adanya pertemuan antara pemimpin Korea Selatan dan Korea Utara di daerah Pamunjom. Pertemuan itu menghasilkan Deklarasi Pamunjon yang berisikan mengenai perdamaian antara kedua negara dan kesepakatan untuk peningkatan kerjasama antara kedua negara. ${ }^{62}$ Hal ini sebenarnya tidak terlepas dari ajang olahraga yang diselenggarakan Korea Selatan pada dua bulan lalu sebelum pertemuan di Pamunjom. Pertemuan di Pamunjom pun dianggap sebagai langkah awal untuk menghentikan pengembangan dan uji coba nuklir Korea Utara.

\subsubsection{Dinamika Hubungan Korea Utara dan Tiongkok}

Kedekatan antara Korea Utara dan Tiongkok sudah berlangsung sejak lama terutama karena letak geografis kedua negara yang berdekatan. Tiongkok menempatkan diri sebagai aktor dibalik layar agar Korea Utara tetap utuh dengan rezim yang telah ada sejak terjadinya Perang Korea. Selain itu, Korea Utara merupakan negara yang penting bagi Tiongkok terutama karena Korea Utara merupakan buffer zone untuk membatasi infiltrasi liberalisme ke Tiongkok. ${ }^{63}$ Oleh Karena itu, Korea Utara cenderung dilindungi oleh Tiongkok bahkan di forum

\footnotetext{
${ }^{62}$ Vina Rosyada. Strategi Perdamaian di Semenanjung Korea . Surabaya: Universitas Islam Negeri Sunan Ampel Surabaya, 2019: hlm 6

${ }^{63}$ Angga Aditama P. hlm. 7
} 
internasional PBB. Tiongkok tidak segan untuk menggunakan hak vetonya untuk melindungi Korea Utara dari sanksi.

Dikarenakan Korea Utara dan Tiongkok merupakan aliansi ekonomi yang dekat, Tiongkok memastikan bahwa Korea Utara tetap dapat berjalan terutama di sektor perekonomian. Korea Utara melakukan ekspor berupa batu bara, biji besi, pakaian tenun, ikan, dan makanan laut. Meskipun Korea Utara selalu mengalami defisit dalam hubungan ekspor-impor ini, hubungan perdagangan Korea UtaraTiongkok tetap berjalan. Berikut merupakan grafik ekspor dan impor Korea Utara terhadap Tiongkok tahun 2013-2017 :

Grafik 2.1

Grafik Jumlah Ekspor Korea Utara ke Tiongkok 2013-2017(dalam Juta USD)

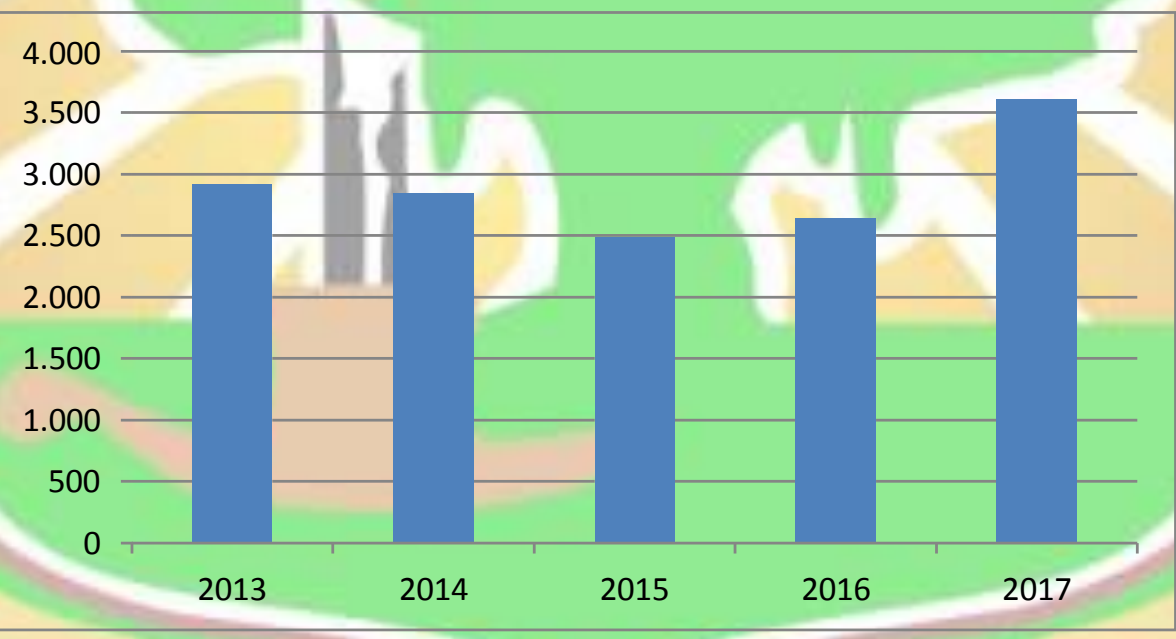

Sumber : U.N Comtrade ${ }^{64}$

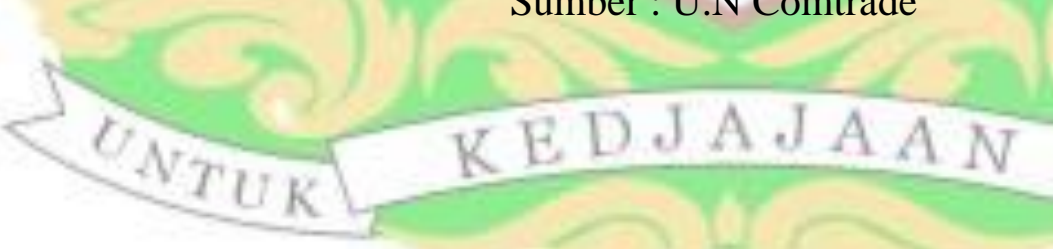

${ }^{64}$ Tia Panca Rahmadhani . Analisis Perubahan Sikap Tiongkok terhadap Korea Utara tentang Isu Nuklir Semenanjung Korea tahun 2006-2018. Lampung: Universitas Lampung, 2019. Hlm. 62 
Grafik 2.2

Grafik Jumlah Impor Korea Utara ke Tiongkok 2013-2017(dalam Juta USD)

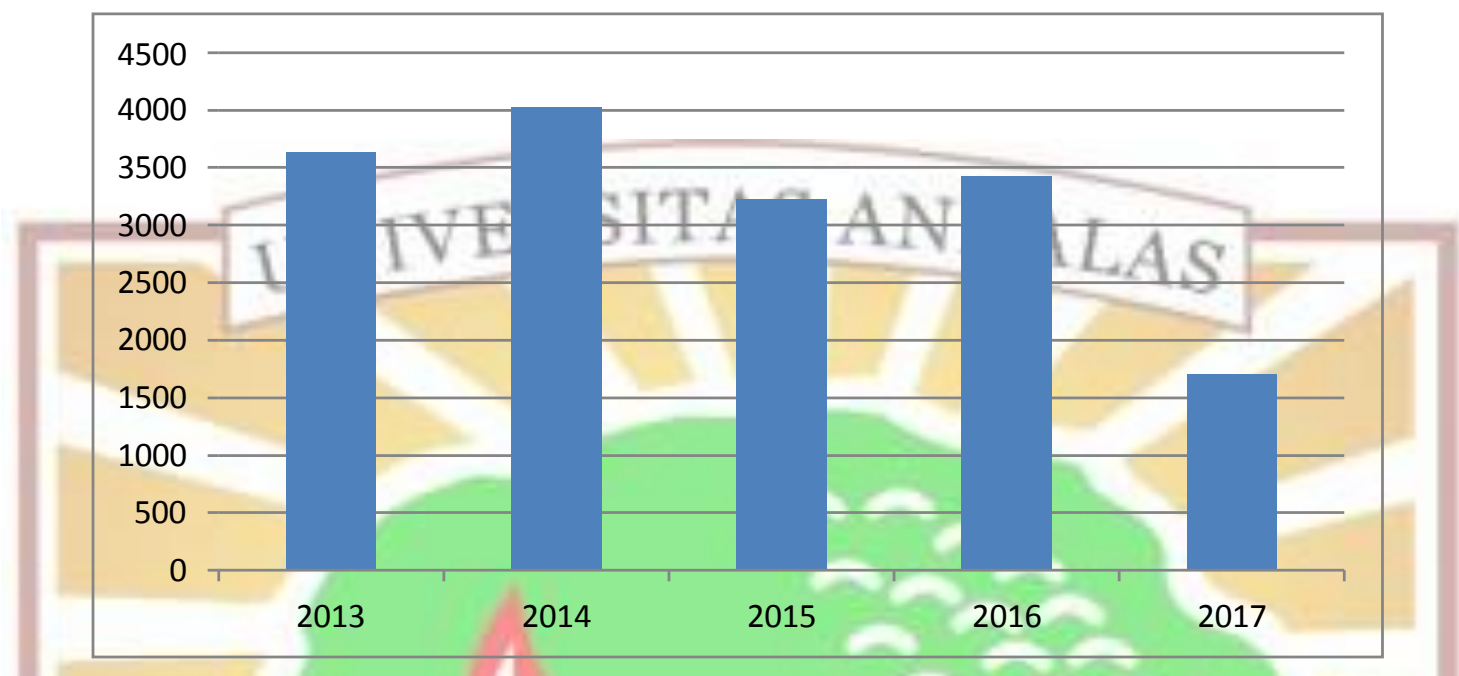

Sumber : U.N Comtrade ${ }^{65}$

Dari grafik tersebut dapat kita lihat bahwa Tiongkok merupakan salah satu sasaran pasar Korea Utara dibuktikan dengan pendapatan Korea Utara yang cenderung stabil dari tahun ke tahun. Tiongkok juga merupakan penyedia utama terhadap pangan, bahan bakar, dan mesin industri Korea Utara. Meskipun terkadang impor dari Tiongkok ke Korea Utara mengalami dinamika yang turun- naik.

Dikarenakan adanya uji coba senjata nuklir Korea Utara yang sulit untuk dikendalikan, akhirnya Tiongkok pun setuju terhadap Resolusi PBB 1718 tahun 2006 yang berisi mengenai penjatuhan sanksi ekonomi. ${ }^{66}$ Kemudian, pada tahun 2010, surat kabar Tiongkok menyatakan bahwa Tiongkok mendukung adanya Reunifikasi Korea di bawah kontrol Korea Selatan. Hal ini dikarenakan Tiongkok juga menganggap bahwa Korea Utara telah melanggar keamanan internasional

65 Tia Panca Rahmadhani. Analisis Perubahan Sikap Tiongkok terhadap Korea Utara tentang Isu Nuklir Semenanjung Korea tahun 2006-2018. Lampung: Universitas Lampung, 2019. Hlm. 62 ${ }^{66}$ Dick K Nanto dan Mark E Manyin. "China-North Korea Relations." Congressional Research Service Journal, 2010: hlm 5 
dengan menguji coba senjata nukirnya, sehingga akan lebih baik jika Korea Utara berdamai. Padahal, Korea Utara dapat mengembangkan program nuklirnya tidak lain karena bantuan dari Tiongkok.

Meskipun Korea Utara merupakan negara yang cukup penting bagi Tiongkok, tetapi hubungan di antara kedua negara ini juga mengalami krisis terutama dalam pembahasan sikap Korea Utara yang terlalu agresif untuk melakukan uji coba nuklirnya. ${ }^{67}$ Meskipun tidak memiliki daya paksa, Tiongkok terus berupaya untuk menjadi host dalam forum mengenai denuklirisasi Korea Utara. Pada tahun 2018, hubungan antara kedua negara berada pada titik terjenuh. Tiongkok terus mendorong Korea Utara untuk melakukan dialog intensif dengan pemimpin Korea Selatan dan menghentikan program nuklirnya. Keputusan ini diambil dengan alasan bahwa Amerika Serikat akan mencabut sanksi ekonomi dan bantuan kepada Korea Utara.

Hubungan bilateral antara Tiongkok dan Utara Selatan menarik perhatian Amerika Serikat karena akan berpengaruh pada keterlibatan Amerika Serikat di Asia Timur. ${ }^{68}$ Tiongkok dapat memainkan peran penting sebagai mediator terhadap Korea Utara, contohnya seperti dorongan untuk melakukan reformasi ekonomi di Korea Utara melalui forum Six Party Talks. Selain itu, Tiongkok juga merupakan negara dengan pendapatan terbesar kedua setelah Amerika Serikat. Hal ini menimbulkan adanya konflik kepentingan antara Tiongkok dan Amerika Serikat yang mendorong kedua negara harus berhubungan dengan Korea Utara.

\footnotetext{
${ }^{67}$ Tia Panca rahmadhani. "Analisis Perubahan Sikap Tiongkok terhadap Korea Utara tentang Isu Nuklir di Semenanjung Korea Tahun 2006-2018. Lampung :Universitas Lampung. 2019 : hlm. 56 ${ }^{68}$ Dick K Nanto dan Mark E Manyin. "China-North Korea Relations." Congressional Research Service Journal, 2010: hlm 2
} 


\subsubsection{Dinamika Hubungan Korea Utara dan Jepang}

Jepang merupakan tetangga terdekat Korea Utara. Namun, negara ini seringkali dilihat sebagai aktor inferior dalam kasus Korea Utara. Jika dilihat dari perannya secara keseluruhan, Jepang merupakan aktor yang mendukung tindakan Amerika Serikat dan Korea Selatan terhadap Korea Utara. Jepang juga menganggap bahwa Nuklir Korea Utara membuat keamanan Asia Pasifik menjadi tidak stabil. Hal ini memungkinkan Jepang melibatkan kekuatan militernya dalam kasus Korea. Hal yang perlu dipahami dari Hubungan Korea Utara dan Jepang ialah tindakan Korea Utara (terutama pengembangan nuklirnya) dinilai penting dalam kebijakan domestik Jepang, Hubungan Korea Utara dan Jepang akan berpengaruh kepada keberlangsungan Asia Timur Laut, serta Jepang juga akan mempengaruhi koordinasi kebijakan terhadap Korea Utara. ${ }^{69}$

Hubungan Korea Selatan dan Jepang bisa dilihat dari sejak tahun 1800an.

Korea merupakan wilayah yang menjadi korban perang Jepang dengan aktor lain, seperti Sino-Japanese war dan Russo-Japanese War. Pada tahun 1910, Korea kemudian dianeksasi oleh Jepang. Korea menderita di bawah kolonialisme Jepang selama kurang lebih 35 tahun. Setelah Jepang kalah dalam Perang Dunia II, Korea mulai mempersiapkan kemerdekaannya. Namun Korea terbagi menjadi dua(Korea Selatan dan Korea Utara), yang mana kedua negara saling berkompetisi untuk mengklaim Korea secara keseluruhan. Akhirnya Perang pun terjadi dengan melibatkan Amerika Serikat, Tiongkok, dan Uni Soviet. Meskipun kedua negara

Korea saling berperang, tetapi keduanya sama-sama memiliki rasa anti-Jepang

\footnotetext{
${ }^{69}$ Linus Hagstorm dan Marie Soderberg. "Taking JapanNorth Korea Relations Seriously : Rationale and Background." Paciffic Affairs 76 (2006): 375.
} 
akibat kolonialisasi. Pada 1970-an terjadi normalisasi hubungan antara ChinaJepang. Hal ini juga berpengaruh pada hubungan Jepang-Korea Utara.

Jepang merupakan pasar bagi Korea Utara dan sumber remitansi dari Penduduk Korea Utara yang menetap di Jepang. Oleh karena itu, Jepang merupakan aktor penting untuk Amerika Serikat berurusan dengan nuklir Korea Utara secara multilateral. Hal tersebut lebih signifikan jika dibandingkan dengan hubungan bilateral Amerika Serikat-Korea Utara secara langsung. ${ }^{70}$ Pada tahun 2001, Jepang sempat menghentikan pembicaraannya dengan Korea Utara karena telah kehabisan cara untuk bernegosiasi dengan negara tersebut. ${ }^{71}$ Sampai saat ini, belum ada hubungan diplomatik secara resmi di antara dua negara, tetapi telah dilakukan beberapa kali pertemuan diplomatik untuk membicarakan warga Jepang yang diculik dan nuklir Korea Utara. Untuk opini publik Jepang sendiri, terdapat $91 \%$ masyarakat Jepang yang memandang Korea Utara secara negatif. ${ }^{72}$

Selanjutnya, Jepang juga merupakan salah satu negara yang menjadi bagian forum multilateral Six Party Talks. Hal ini dilakukan untuk mencapai normalisasi hubungan. Namun hubungan Korea Utara dan Jepang tidak mencapai kondisi yang baik terutama jika mengingat penderitaan yang dialami masyarakat Korea pada masa kolonialisasi Jepang. Oleh karena itu, Korea Utara pada tahun 2016 gencar untuk melakukan uji coba peluncuran rudal ke arah Jepang. Hal ini membuat Jepang berhati-hati dan meningkatkan pertahanan militernya dengan membangun sistem aegis untuk menghancurkan proyrktil yang dikirimkan Korea Utara.

\footnotetext{
${ }^{70}$ Mark E. Manyin. "Japan-North Korea Relations : Selected Issues." CRS Report for Congress, 2003: 3 .

"Victor DCha. "Japan's Engagement Dilemmas with North Korea." Asian Survey (University of California Press), 2014: 561.

${ }^{72}$ Victor D Cha. hlm.558
} 


\subsection{Nuklir Korea Utara dalam Politik Internasional}

Konflik Semenanjung Korea menjadi sorotan internasional karena menyertakan ancaman nuklir Korea Utara. Pengembangan senjata nuklir yang dilakukan oleh Korea Selatan menimbulkan kekhawatiran akan ada perang selanjutnya. Kekhawatiran internasional pun didukung oleh fakta bahwa Korea Utara bukanlah negara yang meratifikasi perjanjian damai senjata nuklir. ${ }^{73}$

Pengembangan senjata nuklir Korea Utara juga menjadi ancaman besar bagi

Korea Selatan sebagai pihak lawan Korea Utara dalam konflik. Terutama jika melihat kembali uji coba nuklir yang diarahkan ke perairan Semenanjung Korea. Hal ini membuat Korea Selatan terus berupaya bernegosiasi dengan Korea Utara terkait perdamaian dan denuklirisasi. Upaya Korea Selatan pun tentu didukung oleh aliansinya, Amerika Serikat dan Jepang. ${ }^{74}$ Oleh karena itu, kedua negara tersebut juga secara aktif melakukan upaya negosiasi maupun pemberian sanksi kepada Korea Utara untuk menghentikan program pengembangan nuklir dan meningkatkan perdamaian di Asia Timur.

Dalam kasus Konflik Semenajung Korea, dapat dilihat bahwa adanya ketergantungan antara negara yang berkonflik dengan negara yang ada dibelakangnya. Begitupun sebaliknya, di mana negara besar juga memiliki kepentingan untuk tetap membantu negara yang berkonflik. Hal tersebut menyebabkan konflik Semenanjung Korea tidak hanya berpengaruh kepada Korea Selatan dan Korea Utara tetapi juga kepada negara-negara yang mendukung mereka. Kehadiran Amerika Serikat dan Tiongkok ikut dipengaruhi dan juga

\footnotetext{
${ }^{73}$ Farel Akbar Bramantya. Alasan Tiongkok Menolak Pembangunan Terminal High Altitude Area Defense di Korea Selatan tahun 2016. Surabaya: Universitas Airlangga, 2018 : 1

${ }^{74}$ Linus Hagstorm dan Marie Soderberg. "Taking JapanNorth Korea Relations Seriously :

Rationale and Background." Paciffic Affairs 76 (2006): 375
} 
mempengaruhi tensi konflik Semenanjung Korea. Sebagai contoh, Tiongkok memprotes kegiatan latihan gabungan antara Korea Selatan dengan Amerika Serikat di sekitar Laut Kuning pada tahun 2010. Tiongkok juga menolak adanya penempatan THAAD di Korea Selatan karena dianggap sebagai pengganggu. ${ }^{75}$

Setelah sekian lama berpisah, sulit untuk menyatukan kembali kedua negara Korea terutama jika mengingat bahwa kedua negara memiliki ideologi masingmasing. Namun, jika terus dibiarkan larut dalam konflik, kedua negara ini juga mempengaruhi sistem internasional. Terutama dengan adanya nuklir Korea Utara yang dianggap mengancam keamanan banyak negara. Oleh karena itu, meskipun sulit, reunifikasi antara dua negara Korea tetap didukung oleh masyarakat internasional terutama oleh aliansi dari kedua negara.

\subsection{Korea Utara sebagai Revisionist State}

Meskipun Korea Utara tidak meratifikasi NPT atau Perjanjian Proliferasi senjata nuklir, tetapi mayoritas negara memiliki paham yang sama bahwa negara yang memiliki senjata nuklir hanyalah lima negara (dibuktikan dengan 170 negara yang menyetujui NPT). Kelima negara tersebut juga memiliki nuklir hanya untuk tujuan menjaga perdamaian. Namun, alih-alih menyepakati perjanjian tersebut, Korea Utara malah mengembangkan senjata nuklir di negaranya sendiri. Meskipun telah mendapat tekanan dari luar, tetapi Korea Utara tetap melanjutkan program pengembangan. Bukan hanya itu, negara ini juga telah melakukan beberapa kali uji coba penembakan nuklir ke negara di sekitarnya. Pasca pengunduran diri dari NPT,

Korea Utara secara berkala menguji coba nuklir pada 2009, 2013, 2016, dan $2017 .^{76}$

\footnotetext{
${ }^{75}$ Farel Akbar Bramantya. hlm. 1

${ }^{76}$ Farel Akbar Bramantya. hlm. 3
} 
Walaupun Korea Utara juga sempat membuka diri untuk bergabung dengan forum multilateral, tetapi Korea Utara sangat sulit untuk mengikuti kesepakatan yang dibuat dalam forum. ${ }^{77}$ Negara ini pun semakin gencar menguji coba nuklirnya sehingga menimbulkan ketegangan di kawasan. Hal ini menyebabkan Korea Utara dianggap sebagai nēgara aggressor. Korea Utara juga dinilai sebagai pihak yang tidak serius untuk mencapai reunifikasi Korea. Hal ini mneyebabkan fluktuasi hubungan antara kedua negara, terutama saat Korea Utara menerapkan 'army centred' yang memicu Korea Selatan menerapkan 'peace keeping force' ${ }^{78}$

Jika melihat Range of State Schweller, Korea Utara dapat dikategorikan menjadi Revisionist State dalam range Wolves. ${ }^{79}$ Sesuai dengan motif Revisionist State, Korea Utara juga tidak puas terhadap sistem yang telah ada. Hal ini diwujudkan dalam pengembangan senjata nuklir untuk mendapatkan posisi bargaining di sistem internasional. Untuk menunjukan ketidakpuasannya, Korea Utara juga cenderung melakukan tindakan yang beresiko agresi dengan terus melakukan uji coba nuklir ke perairan sekitarnya.

Selain itu, Korea Utara menggunakan nuklirnya untuk meningkatkan posisi tawar-menawarnya di sistem internasional. Korea Utara merupakan negara yang lemah secara perekonomian dan ketersediaan pangan. Pada tahun 2016, Korea Utara mencetak angka 28,6\% dalam Global Hunger Index. Namun, Korea Utara malah melakukan uji coba nuklir untuk menarik bantuan dari negara lain

\footnotetext{
77 Andi Purwonodan Ahmad Saifuddin Zuhri "Peran Nuklir Korut Sebagai Instrumen Diplomasi Politik Internasional"dalam Jurnal Ilmu Politik Hubungan Internasional . Vol. 7, No. 2.Unwahas, 2010. Hlm. 5

${ }^{78}$ Rafika Arsyad. "Peluang dan Hambatan Upaya Reunifikasi Korea pada Era Kim Jong Un." Jurnal PIR 3 (2018): 78

${ }^{79}$ Randall L. Schweller. "Bandwagoning for Profit : Bringing the Revisionist State Back in." hlm. 93.
} 
dengan alasan akan segera mengakhiri pengembangan senjata nuklirnya. Hal ini dinilai sebagai strategi diplomasi yang memanfaatkan posisi pihak lain.

Munculnya Kim Jong Un sebagai pemimpin baru di Korea Utara malah semakin membuat negara ini dikenal dengan tindakan agresifnya dalam melakukan pengembangan dan uji coba senjata nuklir. Kim Jong Un juga berjanji untuk mewarisi kebijakan 'military first' yang dilakukan pada pemerintahan Kim Jong Il. ${ }^{80}$ Kim Jong Un pun mengakui bahwa reunifikasi Korea merupakan kepentingan nasional yang ingin dicapai. Hal ini juga dapat dilihat dalam pasal 9 bab I konstitusi Korea Utara. Namun, Korea Utara tidak menginginkan adanya pihak ketiga dalam proses penyatuan kembali.

Korea Utara setuju untuk merencanakan reunifikasi jika Amerika Serikat dan sekutunya tidak ikut campur lagi dalam urusan Korea Selatan. ${ }^{81}$ Dari sini dapat dilihat bahwa terdapat sistem yang ingin diubah Korea Utara. Korea Utara menganggap bahwa Amerika Serikat hanya akan menjadikan Korea sebagai alat untuk mencapai kepentingan. Jika Amerika Serikat terus menanamkan pengaruhnya di Asia Timur, terutama di Semenanjung Korea, maka kemandirian yang menjadi identitas dari ideologi Juche tidak akan tercapai. Oleh karena itu, Korea Utara terus melakukan pengelakan terhadap kesepakatan yang dibuat dengan keterlibatan Amerika Serikat dan cenderung melakukan tindakan agresif di kawasan.

Denuklirisasi Korea Utara dan Reunifikasi Korea akan sulit untuk dicapai jika Korea Utara bersikeras untuk mengubah sistem yang ada, yaitu bahwa pengaruh Amerika Serikat sangat kuat di kawasan Asia Timur. Korea Utara juga

\footnotetext{
${ }^{80}$ Rafika Arsyad. Hlm. 80

${ }^{81}$ Rafika Arsyad. Hlm. 81
} 
tidak menginginkan adanya denuklirisasi karena akan membuat posisi negaranya jatuh kembali. Sementara itu, walaupun Korea Utara mampu berdamai dengan Amerika Serikat, reunifikasi masih akan sulit dicapai jika Korea Utara belum bisa mengejar perekonomian negara tetangganya. Oleh karena itu, Korea Utara seperti

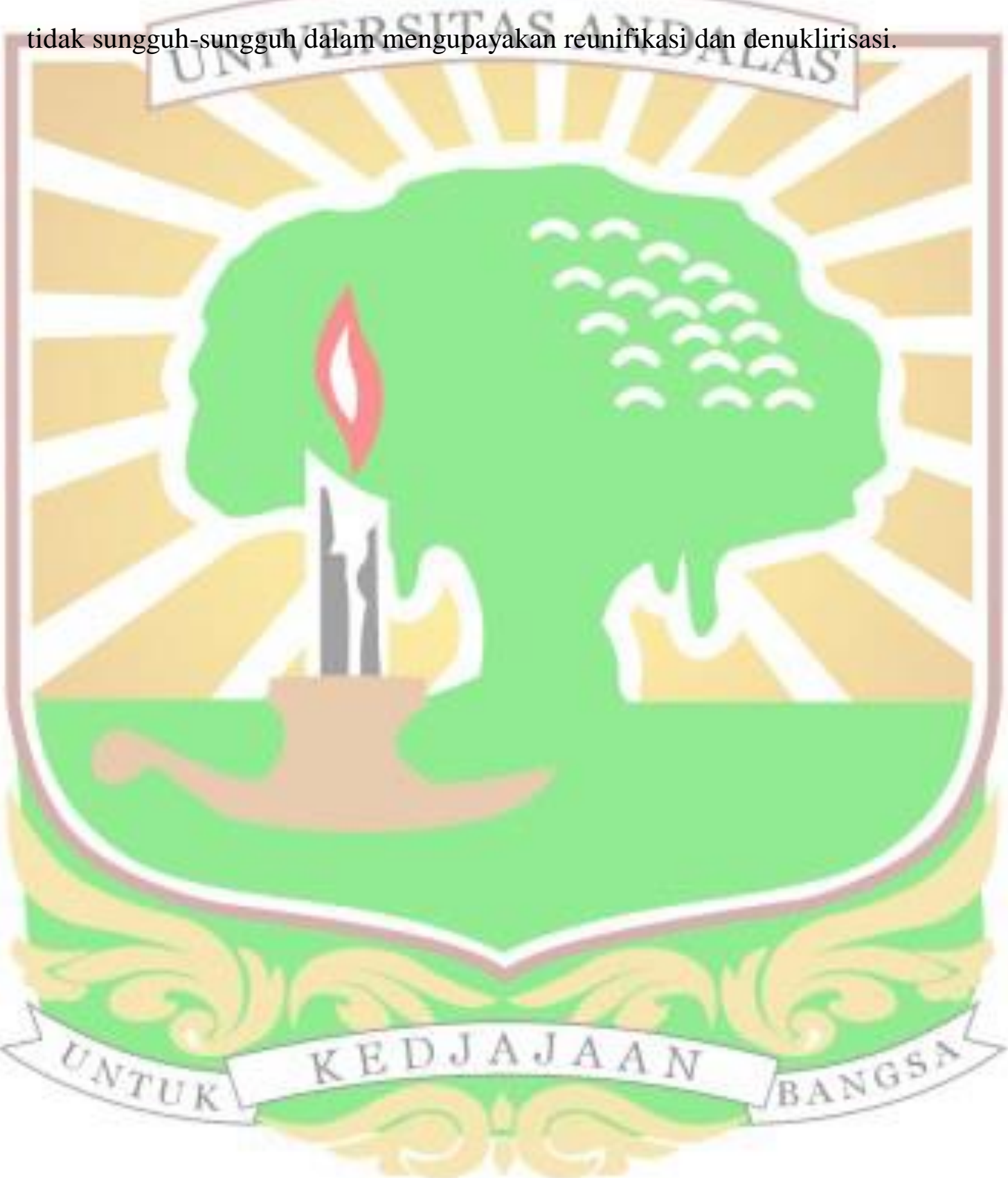




\section{BAB III}

\section{UPAYA AMERIKA SERIKAT DALAM PROSES DENUKLIRISASI KOREA UTARA}

Mengutip dari Gastelum, 1 pelucutan Anuklir merupakan suatu proses mengurangi jumlah dan/atau kapabilitas militer, senjata, dan kekuatan nuklir. Sedangkan denuklirisasi merupakan upaya untuk mengeliminasi infrastruktur yang dapat digunakan untuk memproduksi senjata nuklir. ${ }^{82}$ Merujuk kepada MerriamWebster, 'Denuclearize' berarti "to remove nuclear arms from : prohibit the use of nuclear arms in". ${ }^{83}$ Denuklirisasi secara garis besar merupakan upaya penghapusan senjata nuklir beserta infrastuktur pengembangannya. Dalam upaya mewujudkan penghapusan senjata nuklir, dapat dilihat bahwa Amerika Serikat menganggap pengembangan senjata nuklir Korea Utara dapat menjadi ancaman bagi Amerika Serikat dan aliansinya. Oleh karena itu, pada bab ini akan dibahas mengenai ancaman nuklir Korea Utara terhadap Amerika Serikat. Kemudian, akan dilanjutkan dengan pembahasan upaya Amerika Serikat dalam proses Denuklirisasi Korea Utara.

\subsection{Ancaman Nuklir Korea Utara terhadap Amerika Serikat}

Korea Utara merupakan negara kawasan Asia Timur yang beberapa kali telah melakukan uji coba peluncuran nuklir. Walaupun Korea Utara telah melakukan uji coba peluncuran rudal ke Perairan Semenanjung Korea, negara ini masih memiliki jumlah senjata nuklir yang terbatas. Jumlah yang dimiliki oleh

\footnotetext{
${ }^{82}$ Inda Mustika Permata. "Analisis Konstruktivisme : Perilaku Korea Utara terhadap Denuklirisasi”. Andalas Journal of International Studies. Vol.7, No.2. 2018 Hlm. 108

${ }^{83}$ Merriam Webster. Diakses dari https://www.merriam-webster.com/dictionary/denuclearize pada 20 oktober 2019.
} 
Korea Utara jauh lebih sedikit dibandingkan jumlah senjata nuklir yang dimiliki Amerika Serikat dan negara lainnya. Berikut ini merupakan tabel dari jumlah kepemilikan senjata nuklir beberapa negara di dunia:

Tabel 3.1

Jumlah Kepemilikan Senjata Nuklir Negara

\begin{tabular}{|c|c|c|c|}
\hline Negara & Hulu ledak yang & Hulu ledak & Total inventaris \\
& dikerahkan & lainnya & \\
\hline Amerika Serikat & 1.750 & 4.435 & 6.185 \\
\hline Rusia & 1.600 & 4.900 & 6.500 \\
\hline Inggris & 120 & 80 & 200 \\
\hline Prancis & 280 & 20 & 300 \\
\hline Tiongkok & - & 290 & 290 \\
\hline Pakistan & - & $130-140$ & $130-140$ \\
\hline Israel & - & $150-160$ & $150-160$ \\
\hline Korea Utara & - & $80-90$ & $\mathbf{8 0 - 9 0}$ \\
\hline Total & 3.750 & 10.115 & 13.865 \\
\hline
\end{tabular}

Sumber : world nuclear forces, $\mathbf{2 0 1 8}^{84}$

Dari tabel di atas dapat dilihat bahwa Korea Utara diperkirakan hanya memiliki inventaris 20-30 hulu ledak. Sedangkan Amerika Serikat memiliki 6.185 hulu ledak (1.750 yang telah dikerahkan dan 4.435 hulu ledak lainnya). Dari segi jumlah, dapat dilihat bahwa senjata nuklir Korea Utara bukanlah ancaman serius jika dibandingkan dengan jumlah milik Rusia, Tiongkok dan negara lain yang jumlahnya lebih tinggi dibanding Korea Utara.

${ }^{84}$ SIPRI. hlm . 11 
Namun, terdapat klaim dari Korea Utara bahwa ICBM (Intercontinental

Ballistic Missile) Korea Utara telah mampu mencapai Amerika Serikat. Peluncuran

Hwasong-15 diklaim telah berhasil dengan baik. Peluncuran tersebut mencapai

ketinggian maksimum 4.475 kilometer dan terbang sejauh 950 kilometer. ${ }^{85}$ Berikut merupakan tabel kemâmpuan ICBM Korea Utara: N D ALAS

Tabel 3.2

Kemampuan Misil Balistik Korea Utara

\begin{tabular}{|c|c|c|c|c|c|c|}
\hline Tipe & $\begin{array}{c}\text { US/Other } \\
\text { Designation }\end{array}$ & Tahun & $\begin{array}{c}\text { jarak } \\
\text { tempuh }(\mathbf{k m})\end{array}$ & $\begin{array}{l}\text { Stages } \\
\text { (bahan } \\
\text { bakar) }\end{array}$ & $\begin{array}{c}\text { muatan } \\
x \\
\text { kapasitas } \\
\text { (kg) }\end{array}$ & Peluncuran \\
\hline \multicolumn{7}{|l|}{$\begin{array}{l}\text { Land-based ballistic } \\
\text { Missile }\end{array}$} \\
\hline \multicolumn{7}{|l|}{ ICBMs $(5.500+\mathrm{km})$} \\
\hline Bukkeukseong-3 & $?$ & dev. & $?$ & ? (padat) & $1 x ?$ & TEL C \\
\hline Hwasong-15 & $\mathrm{KN}-22 /$ & dev. & $13.000+$ & 2 (cair) & $1 \times 1.000$ & TEL \\
\hline Hwasong-14 & $\mathrm{KN}-2$ & dev. & 10.400 & 2 (cair) & $1 x ?$ & TEL \\
\hline Hwasong-? & KN-14 & dev. & 9.000 & 3 (cair) & $1 x ?$ & TEL \\
\hline Hwasong-13 & $\mathrm{KN}-08$ & dev. & $5.500+$ & 3 (cair) & $1 x ?$ & TEL \\
\hline Taepo Dong-2 & $\begin{array}{l}\text { Taepo } \\
\text { Dong-2 }\end{array}$ & 2012 & $12.000+$ & 3 (cair) & $1 \times 800+$ & Selesai \\
\hline \multicolumn{7}{|l|}{$\begin{array}{l}\text { IRBMs (3.000-5.500 } \\
\mathrm{km} \text { ) }\end{array}$} \\
\hline Hwasong-13 & $\mathrm{KN}-17$ & dev. & $3.300-4.500$ & 1 (cair) & $1 \times 1.000$ & TEL \\
\hline Hwasong-10 & $\begin{array}{l}\text { Musudan, } \\
\text { BM-25 } \\
\end{array}$ & 2017 & $3.000+$ & 1 (cair) & $1 \times 1.000$ & $<50 \mathrm{TEL}$ \\
\hline \multicolumn{7}{|l|}{$\begin{array}{l}\text { MRBMs } \\
3.000 \mathrm{~km})\end{array}$} \\
\hline Bukkeukseong-2 & $\mathrm{KN}-15$ & dev. & $1.000+$ & 1 (padat) & $1 x ?$ & TEL C \\
\hline Hwasong-7 & Nodong & 1993 & $1.200+$ & 1 (cair) & $1 \times 1.000$ & $<100 \mathrm{TEL}$ \\
\hline Hwasong-9 & $\begin{array}{l}\text { Scud ER, } \\
\text { KN-4 }\end{array}$ & 2016 & 1.000 & 1 (cair) & $1 \times 500$ & TEL \\
\hline \multicolumn{7}{|l|}{$\begin{array}{l}\text { Submarine-launched } \\
\text { ballistic missiles }\end{array}$} \\
\hline Bukkeokseong-1 & $\mathrm{KN}-11$ & dev. & $1.000+$ & 1 (padat) & & SBB \\
\hline
\end{tabular}

Sumber : North Korean Ballistic Missile 86

\footnotetext{
${ }^{85}$ VOA Indonesia. "Uji ICBM Korea Utara dikutuk secara Internasional”. 29 November 2019.

Diakses dari https://www.voaindonesia.com/amp/4141870.html pada 30 November 2019.

${ }^{86}$ Hans M. Kristensen dan Robert S. Norris. "North Korean Nuclear Capabilities, 2018”. Bulletin of the Atomic Scientists. Vol. 74. No. 1. Routledge. 2018 : hlm. 42
} 
Tabel di atas memperlihatkan bahwa misil Korea Utara tipe Hwasong-15 telah mampu menjangkau jarak hingga $13.000 \mathrm{~km}$. Dengan jarak tempuh ini, Korea Utara dapat menjangkau Amerika Serikat, yang mana jarak Pyongyang ke Washington DC hanya berjarak $10.400 \mathrm{~km}$ saja. Terdapat banyak perdebatan mengenai kemampuan misil Korea Utara ini, karena meskipun Hwasong-15 telah mampu menempuh jarak hingga $13.000 \mathrm{~km}$, tetapi misil ini belum mampu membawa muatan nuklir. ${ }^{87}$ Dengan seringnya uji coba peluncuran nuklir Korea Utara yang disertai kemampuan jarak tempuh misil yang terus meningkat, wajar saja jika Amerika Serikat juga merasa terancam walaupun jumlah hulu ledak milik Korea Selatan hanya berjumlah sedikit.

\subsection{Upaya Amerika Serikat Dalam Proses Denuklirisasi Korea Utara}

Meskipun jumlah senjata nuklir yang dimiliki Korea Utara sedikit, tetapi Amerika Serikat terus berupaya mewujudkan denuklirisasi terhadap Korea Utara. Hal tersebut dikarenakan adanya perkiraan misil Korea Utara telah mampu mencapai Amerika Serikat. Selain itu, karakteristik pemimpin dan ideologi yang dianut oleh Korea Utara membuat negara ini agresif dan tidak dapat dikontrol sehingga uji coba nuklir Korea Utara merupakan hal yang tidak dapat diprediksi. Oleh karena itu, Amerika Serikat perlu melakukan pembaharuan strategi nasional untuk mengupayakan denuklirisasi. ${ }^{88}$ Upaya-upaya tersebut meliputi :

$\overline{87}$ VOA Indonesia. "Uji ICBM Korea Utara dikutuk secara Internasional”. 29 November 2019. Diakses dari https://www.voaindonesia.com/amp/4141870.html pada 30 November 2019.

${ }^{88}$ Windhy Dewitasari. Strategi Penangkalan Nuklir Korea Utara Periode 2003-2010. Universitas Indonesia, 2011: HIm.54
} 


\subsubsection{Upaya Amerika Serikat melalui Six Party Talks}

Untuk mencegah situasi yang semakin tidak kondusif di Asia Timur, maka dibuatlah sebuah usaha diplomatik. Meskipun inisiator dari upaya ini adalah Tiongkok, tetapi dalam upaya ini, Amerika Serikat juga sangat berperan dalam mendesak denuklirisasi di Korea Utara, yaitu sebuah proses terwujudnya penghapusan kepemilikan senjata nuklir Korea Utara. ${ }^{89}$ Upaya diplomatik yang dilakukan adalah memprakarsai perundingan multilateral yang dikenal dengan Six Party Talks pada tahun 2003. Six Party Talks yang dibentuk Agustus 2003 merupakan serangkaian upaya diplomatik multilateral untuk menggandeng Korea Utara bergabung ke dalam meja perundingan yang melibatkan Amerika Serikat, Rusia, Jepang, Tiongkok, Korea Selatan..$^{90}$

Pada putaran kedua Six Party Talks yang diselenggarakan di Beijing pada 25-28 Februari 2004, Amerika Serikat menegaskan kepada Korea Utara untuk mengakhiri pengayaan program uranium yang telah dikerjakannya dengan bantuan Pakistan. Amerika Serikat juga menekankan kembali kepada Korea Utara bahwa pembongkaran program nuklir secara lengkap yang dapat diverifikasi dan tidak dapat diubah kembali harus segera dilaksanakan Pyongyang. Desakan ini terus berlanjut pada putaran berikutnya.

Ketika putaran kelima yang berlangsung pada tahun 2005, Kementerian Keuangan Amerika Serikat menyatakan Banco Delta Asia (BDA), sebuah bank di Macau dimana Korea Utara memiliki rekening, sebagai bank yang diduga melakukan atau menerima dana hasil pencucian uang Korea Utara. Macau merespon dugaan tersebut dengan membekukan sekitar \$24 juta dana yang

\footnotetext{
${ }^{89}$ Muhammad Nabil. hlm. 3

${ }^{90}$ Muhammad Nabil. hlm.5
} 
dimiliki Korea Utara. Sebagai salah satu syarat untuk melanjutkan Six Party Talks, Korea Utara meminta agar pembekuan rekening tersebut dibatalkan terlebih dahulu. Pada 13-19 September 2005, forum multilateral ini menghasilkan sebuah pernyataan bersama (Joint Statement) yang akan menjadi sebuah pedoman atas prinsip damai untuk mengakhiri krisis nuklir Korea Utara. Menurut pernyataan bersama yang dideklarasikan pada 19 September tersebut, semua pihak yang terlibat sepakat untuk menyiapkan Semenanjung Korea yang bebas nuklir dan diverifikasi secara damai. Semua pihak juga berjanji untuk membuat upaya bersama untuk mewujudkan perdamaian abadi dan keamanan.

Pertemuan di Beijing pada bulan Februari 2007 menghasilkan perjanjian Initial Actions for the Implementation of Joint Statement. ${ }^{91}$ Perjanjian ini berisi penutupan dan penyegelan fasilitas Yongbyon, mendikusikan daftar-daftar seluruh program nuklir Korea Utara, penarikan tuduhan Korea Utara sebagai negara pendukung terorisme. Perjanjian ini juga merupakan langkah awal bagi pembicaraan bilateral Korea Utara dengan AS dan Jepang, penyediaan 50.000 ton bahan bakar minyak bagi Korea Utara dalam jangka waktu 60 hari. Lima kelompok kerja tersebut adalah: Normalisasi Hubungan Korea Utara-AS, Denuklirisasi Semenanjung Korea, Normalisasi Hubungan Korea Utara-Jepang, Kerjasama Ekonomi dan Energi, Mekanisme Perdamaian dan Keamanan Asia Timur. Keenam pihak kembali menegaskan pentingnya upaya multilateral dengan menyatakan bahwa semua pihak sepakat mengambil langkah-langkah

${ }^{91}$ Muhammad Nabil. Hlm. 56 
terkoordinasi untuk melaksanakan pernyataan bersama secara bertahap, dimana sejalan dengan prinsip “action for action”.

Tidak berhenti sampai disana, Perundingan Six Party tersebut sekali lagi diumumkan pada Januari 2014 melalui pejabat Kantor Berita Xinhua, China. Kemudian, untuk menindaklanjuti hal ini, Resolusi DK PBB 2270 yang diadopsi pada 2 Maret 2016 yang telah dimodifikasi mengenai sanksi rezim. Dari rangkaian upaya yang dilakukan tersebut dapat dilihat bahwa Six Party Talks merupakan forum yang memungkinkan keenam pihak tetap melakukan negosiasi walaupun hasilnya tidak selalu maksimal. Dalam forum ini juga Amerika Serikat merupakan pihak yang bersikeras untuk menghapus pengembangan senjata nuklir Korea Utara.

\subsubsection{Upaya Amerika Serikat dalam Pembentukan Resolusi Dewan}

\section{Keamanan PBB (UNSCR)}

Setelah Korea Utara mulai menguji coba nuklirnya pada Mei 2009, Presiden Barack Obama menyatakan bahwa uji coba tersebut akan mengancam perdamaian dunia dan telah melanggar UNSCR $1718 .{ }^{92}$ Pada 13 Juni 2009, Amerika Serikat melalui kantor beritanya mengumumkan bahwa Korea Utara tetap melanjutkan pengayaan uranium padahal sudah menerima sanksi dari PBB. Kemudian Bill Clinton bertemu dengan Kim Jong Il untuk menjamin pembebasan dua orang wartawan Amerika Serikat. Amerika Serikat pada tahap ini ialah mendorong terbentuknya United Nations Security Coucil Resolution (UNSCR)

${ }^{92}$ Krisandhy Ertanto Rantung. "Kebijakan Luar Negeri Amerika Serikat terhadap Program Pengembangan Nuklir Korea Utara pada Masa Pemerintahan Barack Obama". Universitas Komputer Indonesia. 2016 : hlm.3 
pada tahun 2009 terkait keamanan Asia Timur, yaitu Resolusi 1887 dan Resolusi $1874 .{ }^{93}$

Resolusi 1874 membahas mengenai peringatan terhadap Korea Utara. Resolusi ini disesuaikan dengan beberapa resolusi sebelumnya yaitu resolusi 825 (1993), resolusi 1540 (2004), resolusi 1695 (2006), dan ressolusi 1718 (200 6). ${ }^{94}$ Ketentuan resolusi meliputi memberi wewenang kepada negara anggota untuk memeriksa sesuai Undang-Undang Nasional dan hukum internasional terkait dengan nuklir Korea Utara. Selain itu, resolusi ini mewajibkan pemerintah Korea Utara untuk segera mengikuti forum Six Party Talks kembali dan mencegah anggaran dana untuk mengembangkan senjata nuklir. Resolusi ini juga memerintahkan kepada negara anggota untuk tidak memberikan bantuan keuangan kepada Korea Utara dengan alasan kemanusiaan atau pembangunan. Tak hanya itu, resolusi ini juga memperluas sanksi embargo untuk Korea Utara. ${ }^{95}$

Tak jauh berbeda dengan resolusi 1874, resolusi 1887 juga merupakan resolusi yang ditujukan untuk denuklirisasi Korea Utara. ${ }^{96}$ Dengan resolusi ini, Dewan Keamanan PBB menyatakan mewujudkan dunia yang lebih aman tanpa nuklir sesuai yang telah diatur oleh NPT dengan cara mempromosikan stabilitas internasional, dan berdasarkan prinsip keamanan bersama. Oleh karena itu, Korea Utara diminta untuk mematuhi NPT dan mau berkerjasama dengan IAEA, serta ikut dalam upaya negara lain untuk menetapkan langkah-langkah untuk mengurangi senjata nuklir.

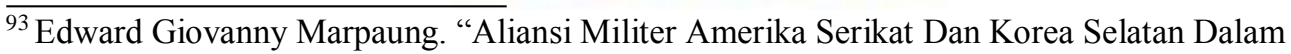
Upaya Menjaga Stabilitas Keamanan Semenanjung Korea (2010-2016)”. Universitas komputer Indonesia. 2017: 4

${ }^{94}$ UNSRC. Resolusi 1874 (2009). Diakses dari https://unsrc.com

95 UNSRC. Resolusi 1874 (2009). Diakses dari https://unsrc.com

96 UNSRC. Resolusi 1887 (2009). Diakses dari https://unsrc.com
} 
Kemudian, Amerika Serikat juga mendorong adanya Resolusi UNSCR (United Nations Security Council Resolution) no. 2094 yang dikeluarkan pada 7 April 2013. Resolusi ini secara subtantif menyalahkan program pengembangan nuklir Korea Utara dan memberlakukan sanksi keuangan. Dalam menanggapi hal ini, Korea Utara justru semakin agresif untuk melakukan provokasi uji coba nuklirnya yang membuat ketegangan di kalangan masayarakat internasional. Dengan adanya dorongan kuat dalam pembuatan resolusi di atas, dapat dilihat bahwa Amerika Serikat memang bersungguh-sungguh untuk mengupayakan denuklirisasi di Semenanjung Korea.

\subsubsection{Upaya Amerika Serikat melalui Pivot to Asia}

Pemerintah Amerika Serikat berada dalam tahap awal dalam mengorientasikan ulang elemen-elemen penting kebijakan luar negerinya terhadap kawasan Asia Pasifik dan mendorong mitra kerjasama di luar kawasan. Strategic pivot atau upaya rebalancing diberlakukan pada tahun $2009 .{ }^{97}$ Strategi ini didasarkan pada pengakuan bahwa politik dan ekonomi abad ke-21 akan berada di kawasan Asia Pasifik. Untuk mendapatkan pergeseran dinamika geopolitik global ini dan tumbuh secara berkelanjutan, Amerika Serikat membangun hubungan diplomatik, ekonomi, pembangunan, dan keamanan dengan kawasan Asia. Upaya penyeimbangan kembali ini dilakukan untuk meningkatkan fokus melibatkan diri ke kawasan Asia karena sebenarnya keterlibatan Amerika Serikat di kawasan ini sudah dilakukan sejak lama.

Meskipun, kebijakan ini mencakup kebijakan Amerika Serikat terkait Asia secara keselurulan. Namun, dalam mewujudkan Pivot to Asia, Amerika Serikat

\footnotetext{
$\overline{97}$ Kurt Campbell da Brian Andrews. "Explaiing the US 'Pivot to Asia"'. London : Catham House.
} 2013 : hlm. 2 
dibawah kepemimpinan Presiden Obama melakukan beberapa upaya, khususnya di kawasan Asia Timur. Upaya tersebut meliputi memperkuat aliansi Amerika Serikat, dalam kemitraan dengan sekutunya, Amerika Serikat berupaya menciptakan tatanan keamanan yang stabil dalam membangun strategi kepercayaan dalam wilayah dan menyediakan konteks untuk membangun hubungan yang lebih dekat. Aliansi Jepang-Amerika Serikat dan Korea Selatan- Amerika Serikat diperkuat dengan peningkatan kerjasama militer, seperti latihan gabungan.

Pengaplikasian Pivot to Asia pun dilakukan dalam peningkatan kerjasama trilateral yang diwujudkan dengan cara pertemuan tiga negara (Amerika Serikat, Jepang dan Korea Selatan) seperti yang dilaksanakan pada tanggal 31 Maret $2016 .{ }^{98}$ Hal ini dilakukan untuk membicarakan perlunya meyakinkan Korea Utara untuk menghentikan program nuklirnya demi stabilitas keamanan di Asia Timur. ${ }^{99}$ Ketiga negara juga akan memastikan negara lain, terutama negara di kawasan Asia, mau berkerjasama untuk melaksanakan kewajiban mereka di bawah Resolusi UNSC (Dewan Keamanan PBB) 2270.

\subsubsection{Upaya Amerika Serikat melalui Strategic Patience}

Kegagalan Amerika Serikat dalam menangani agresivitas Korea Utara dalam kesepakatan yang telah dilakukan membuat Amerika Serikat perlu menerapkan pendekatan yang berbeda terhadap Korea Utara. Pada saat pemerintahan Obama di Amerika Serikat, salah satu kebijakan yang dikeluarkan untuk menanggapi isu nuklir Korea Utara ialah dengan kebijakan strategic patience. Upaya ini merupakan cara untuk mendorong Korea Utara untuk

\footnotetext{
${ }^{98}$ Krisandhy ertanto Rantung. hlm. 9

${ }^{99}$ Krisandhy ertanto Rantung. Hlm.10
} 
membuka diri dalam forum negosiasi denuklirisasi dengan cara 'wait' (menunggu) dan menekan rezim agresif Korea Utara. ${ }^{100}$ Kebijakan ini tidak diwujudkan melalui pemberian sanksi tetapi lebih kepada strategi 'watching, waiting, and anticipating'. ${ }^{101}$ Hal ini dilakukan karena bagi Amerika Serikat, Korea Utara merupakan aktor yang irasional sehingga tindakannya tidak dapat diprediksi. Amerika Serikat akan terancam jika salah mengambil langkah untuk menanggapi agresivitas Korea Utara.

Beberapa ahli mendeskripsikan bahwa strategi ini seperti Amerika Serikat sedang menyatakan "take it, or leave it" kepada Korea Utara. ${ }^{102}$ Bagi pemerintahan Obama, Korea Utara akan segera membuka diri terhadap negosiasi karena adanya faktor bencana, kekurangan pangan dan kebobrokan ekonomi di Korea Utara. Rezim dengan kondisi ini lambat laun akan runtuh. Selain itu, strategi ini juga meliputi upaya untuk meredam agresivitas Korea Utara dengan upaya menyatukan kembali dua Korea. Menurut Mark Fitzpatrick, upaya yang patut dilakukan dalam mendukung Strategic Patience ini ialah dengan mempromosikan penggunaan sanksi dan kontrol informasi. Hal ini dikarenakan rezim Korea Utara tak dapat mengontrol arus informasi. ${ }^{103}$

Strategi ini secara garis besar bertujuan untuk membuat Korea Utara dengan sendirinya membuka diri untuk negosiasi permasalahan denuklirisasi. Namun,Strategi ini dianggap kurang efektif karena sambil menunggu Konsesi

Korea Utara, Amerika Serikat akan memiliki wawasan yang dangkal mengenai

\footnotetext{
$\overline{{ }^{100} \text { Krisandhy ertanto Rantung. hlm. } 9}$

${ }^{101}$ Jong Kun Choi. hlm 57

102 Jong Kun Choi. hlm. 58

${ }^{103}$ Jong Kun Choi. Hlm. 61
} 
karakter pemimpin dan kemampuan nuklir Korea Utara. ${ }^{104}$ Strategi ini juga belum dapat merumuskan cara untuk membawa IAEA kembali ke situs nuklir Korea Utara untuk memantau kegiatan nuklirnya. Oleh karena itu, strategi ini hanya bertahan pada masa pemerintahan Obama, karena pada pemerintahan Trump, strategic patience dianggap tēlah usai. Hal ini diungkapkan oleh/Mike Pence pada 2017.

\subsubsection{Upaya Amerika Serikat melalui USFK}

USFK (US Forces Korea) adalah pasukan Amerika Serikat yang didirikan pada 1957 sebagai bagian dari Penjanjian Pertahanan Bersama Korea SelatanAmerika Serikat (Mutual Defense Treaty). ${ }^{105}$ USFK juga dianggap sebagai simbol persekutuan antara Amerika Serikat dengan Korea Selatan. ${ }^{106}$ Melalui USFK, Korea Selatan dan Amerika Serikat melakukan latihan gabungan pertamanya sejak tahun 1969 dengan nama Focus Retina Exercise dibawah komando UNC. Latihan ini sendiri memiliki tujuan untuk menangkal Korea Utara dari kemungkinan perang lanjutan, menyediakan kesempatan latihan pada tingkat divide untuk kekuatan militer kedua negara, serta mengembangkan taktik yang disesuaikan dengan geografis. Latihan gabungan ini tidak hanya didukung oleh finansial Amerika Serikat tetapi juga melalui Special Measures Agreements Korea Selatan.

\footnotetext{
${ }^{104}$ Jong Kun Choi. Hlm. 58

${ }^{105}$ Seong-Hyon Lee. "The Shift of Security Environment in Northeast Asia : The U.S. China Conflict and Its Implications for Korea." Journal for Peace and Nuclear Disarmament, 2018: hlm.2

${ }^{106}$ Hee Jea Lim. Korea is Really Matter to U.S.? The Relationship about USFK and ROK-U.S. Alliance. Halmstad University, 2011. Hlm. 4
} 
Dengan adanya USFK, maka Korea Selatan mendapat dukungan dari kontribusi Amerika Serikat dalam empat aspek. ${ }^{107}$ Pertama, Misi USFK adalah implementasi peringatan dini yang mendeteksi tanda melalui operasi aset informasi lanjutan. Kedua, USFK menjaga dan mengembangkan kesiapan melalui latihan gabungan angkatan bersenjata. Ketiga, USFK memainkan peran kunci sebagai bala bantuan untuk Amerika Serikat dalam keadaan darurat. Keempat, USFK telah berkontribusi tidak hanya tinngkat strategis militer tetapi juga dimensi ekonomi.

Hal ini dapat dilihat berkurangnya pengeluaran pertahanan dan keseluruhan investasi revitalisasi dengan menyingkirkan ketidakpastian keamanan.

Dari sejak pertama kali dibentuk, jumlah pasukan dan kekuatan militer USFK mengalami beberapa perubahan. Hal ini juga dipengaruhi oleh keikutsertaan USFK dalam beberapa pengerahan militer Amerika Serikat di wilayah tertentu.

Berikut merupakan tabel kekuatan militer USFK :

Tabel 3.3

Military Strength and Employment of USFK

\begin{tabular}{|c|c|c|c|c|c|c|}
\hline Pembagian & Official & Tentara & $\begin{array}{c}\text { Total } \\
\text { Pasukan }\end{array}$ & $\begin{array}{c}\text { Warga } \\
\text { Sipil } \\
\text { Amerika } \\
\text { Serikat }\end{array}$ & $\begin{array}{c}\text { Pekerja } \\
\text { Korea } \\
\text { Selatan }\end{array}$ & total \\
\hline $\begin{array}{c}\text { The Eight } \\
\text { U.S. Force }\end{array}$ & 2.972 & 19.908 & 22.880 & 1.171 & 7.923 & 54.854 \\
\hline $\begin{array}{c}\text { Dan lain- } \\
\text { lain }\end{array}$ & 551 & 3.045 & 3.596 & 404 & 887 & 8.483 \\
\hline Sub total & 3.523 & 22.953 & 26.476 & 1.575 & 8.810 & 63.337 \\
\hline $\begin{array}{c}\text { Angkatan } \\
\text { udara }\end{array}$ & 885 & 7.259 & 8.114 & 154 & 903 & 17.315 \\
\hline $\begin{array}{c}\text { Angkatan } \\
\text { laut }\end{array}$ & $\mathrm{K}$ & 23 & 223 & 306 & 1 & 101 \\
\hline $\begin{array}{c}\text { Korps } \\
\text { marinir }\end{array}$ & 32 & 43 & 75 & - & - & 150 \\
\hline Departemen & 13 & 24 & 37 & 665 & 447 & 1.186 \\
\hline
\end{tabular}

${ }^{107}$ Hee Jea Lim. Hlm. 18 


\begin{tabular}{|c|c|c|c|c|c|c|}
\hline negara & & & & & & \\
\hline Total & 8.059 & 53.455 & 61.484 & 3.970 & 19.071 & 146.039 \\
\hline \multicolumn{7}{|c|}{ Sumber : Military Strength and Employment of USFK ${ }^{\mathbf{1 0 8}}$}
\end{tabular}

Tabel di atas menunjukan bahwa Jumlah total USFK mencapai hampir 150.000 pasukan dan staf. Angkatan Udara bahkan mencapai 17.315 dan tentara The Eight U.S. Forces mencapai hampir 20.000 Dorang. Pasukan ini juga melaksanakan latihan gabungan secara berkala di kawasan Asia Timur. Dari tabel tersebut dapat dilihat bahwa Amerika Serikat memang berfokus pada upaya menjaga stabilitas Semenanjung Korea melalui pasukan USFK. USFK diharapkan menjadi perlindungan militer untuk Korea Selatan dalam menghadapi ancaman nuklir Korea Utara. Dengan adanya pasukan ini juga diharapkan Korea Utara akan merasa terdesak untuk segera menghapus pengembangan senjata nuklirnya.

Penempatan USFK memang diklaim untuk menjaga stabilitas kemanan Semenanjung Korea serta ditujukan untuk menekan Korea Utara agar segera mewujudkan denuklirisasi. Namun, pada kenyataannya upaya ini hanya memperparah keadaan karena Korea Utara semakin terpancing untuk melakukan uji coba nuklir di kawasan Semenanjung Korea. Hal ini terlihat dari uji coba nuklir Korea Utara pada tahun 2017 sebagai bentuk respon Korea Utara terhadap latihan gabungan Korea Selatan dengan Amerika Serikat. ${ }^{109}$

\subsubsection{Upaya Amerika Serikat melalui Penempatan Terminal High Altitude Area Defense (THAAD) di Korea Selatan,}

Pasca Pengunduran diri Korea Utara dari NPT di tahun 2003, Korea Utara

melakukan uji coba nuklir secara berkala. Sampai saat ini, Korea Utara telah

\footnotetext{
${ }^{108}$ Hee Jea Lim. Hlm. 18

${ }^{109}$ CNN Indonesia."ResponNuklir Korea Utara, AS Ancam Aksi Militer Skala Besar". 4

September 2017. Diakses darihttps://m.cnnindonesia.com/internasional/201709033233257-113-

239201/respon-nuklir-korea-utara-as-ancam-militer-skala-besar pada 1 Desember 2019
} 
dikonfirmasi memiliki rudal balistik jarak pendek dan menengah, termasuk 500 unit rudal Hwasong-5, dan Hwasong-6 dengan jangkauan 300-500 km, serta 200 unit sistem No-Dong dengan jangkauan $1.000 \mathrm{~km} .{ }^{110}$ Sementara itu, Amerika Serikat yang telah bersekutu dengan Korea Selatan sejak lama mengambil tindakan dengan penempatan sebuah sistem yang dirancang untuk menembak jatuh rudal balistik jarak pendek dan menengah. Sistem ini dinamakan THAAD (Terminal High Altitude Area Defense) dan didirikan pada 7 Februari 2016. Hal ini dilakukan karena menurut Amerika Serikat, uji coba nuklir Korea Utara akan membahayakan aliansinya, Korea Selatan.

Sistem THAAD tidak membawa hulu ledak tetapi tergantung pada pelacakan inframerah canggih untuk menghentikan target dan dampak energi kinetik yang ditimbulkan oleh penghancuran rudal. Sistem ini memiliki jangkauan $200 \mathrm{~km}$ dengan kecepatan 8,24 Mach. Selain itu, sistem ini juga dilengkapi radar yang memiliki jangkauan $1.000 \mathrm{~km}$ dan daya tembak hingga 72 interceptor per baterai. Sistem THAAD dapat menutup celah battlespace antara PAC-3 yang hanya menjangkau lapisan atmosfer. ${ }^{111}$

Pemasangan THAAD dilakukan sehari setelah adanya pelanggaran Korea Utara yang meluncurkan empat rudal. Laksamana Harry Harris mengemukakan bahwa Amerika Serikat akan tetap berkomitmen untuk menjaga aliansi Amerika Serikat walaupun kesepakatan pemasangan THAAD terjadi pada masa pemerintahan Presiden Barrack Obama. Meskipun tujuan penempatan THAAD adalah untuk melindungi Korea selatan, tetapi hal ini memicu kontroversi dari banyak pihak. Penempatan THAAD di Korea Selatan dinilai hanya akan

\footnotetext{
$\overline{{ }^{110} \text { Farel Akbar Bramantya. hlm. 1-2 }}$

${ }^{111}$ Rahmalia Ayu Widayanti. hlm. 98
} 
memperburuk hubungan antara Korea Utara dan Korea Selatan dan menghambat adanya stabilitas di Semenanjung Korea.

Terminal yang ditempatkan di Seongsan, Seongju ini juga berdekatan dengan lokasi warga. ${ }^{112}$ Oleh karena itu, penempatan ini ditolak oleh masyarakat Korea Selatan karena dikhawatirkan akan Amemberikan efek pencemaran lingkungan dari sistem pertahanan tersebut. ${ }^{113}$ Pemasangan terminal menimbulkan polusi suara dan beberapa alat pemasangan juga merusak jaln di sekitar lokasi. Hingga tahun 2017, baru dua alat pelontar yang telah ada di Korea Selatan. Alat tersebut akan tetap dibiarkan di Korea Selatan, tetapi pemasangan alat lainnya masih ditangguhkan oleh Presiden Korea Selatan, Moon Jae In sampai penilaian dampak lingkungan selesai.

Pemasangan THAAD merupakan upaya Amerika Serikat untuk melindungi Korea Selatan dari ancaman Korea Utara. Namun, upaya ini masih dinilai kontroversial karena menuai protes dari masyarakat Korea Selatan dan Tiongkok yang mengatakan bahwa THAAD hanyalah proyek untuk mengawasi Tiongkok. Selain itu, penempatan ini juga malah memperburuk hubungan dengan Korea Utara sehingga denuklirisasi semakin jauh untuk dinegosiasikan.

\subsubsection{Upaya Amerika Serikat melalui Pertemuan Bilateral}

Ketika peneliti membahas mengenai upaya denuklirisasi, maka tidak akan terlepas dari upaya reunifikasi. Hal tersebut dikarenakan kedua hal tersebut

dilakukan untuk mencapai stabilitas keamanan Semenanjung Korea. Diplomasi terhadap Korea Utara dilakukan dalam mode triangular, yang mana hubungan

\footnotetext{
${ }^{112}$ Qonita, Maulida Ibnaty. "Ananlisis Perubahan Kebijakan Luar Negeri Korea Selatan dalam Pemasangan Sistem Terminal High Altitude Area Defense (THAAD)." Journal of International Relations (Universitas Diponegoro) 5 (2019): hlm. 798

${ }^{113}$ Rahmalia Ayu Widayanti. hlm. 99
} 
Korea Utara-Amerika Serikat lebih berfokus pada denuklirisasi. Sedangkan diplomasi Korea Utara-Korea Selatan lebih menitikberatkan pada rezim perdamaian. ${ }^{114}$ Oleh karena itu, Donald Trump mendukung pertemuan bilateral antara Presiden Moon Jae In dan Kim Jong Un pada 27 April 2018. Presiden Amerika Serikat ini juga merencanakan pertemuan dengan Kim Jong Un untuk melakukan pembahasan nuklir. ${ }^{115}$ Pada tahun-tahun sebelumnya, Tiongkok memang berpengaruh besar terhadap proses permaian Korea karena Korea Utara dan Amerika Serikat memiliki hubungan yang tidak baik. Namun, eksistensi Tiongkok menjadi berkurang dikarenakan pada tahun 2018, Korea Utara dan Amerika Serikat mengadakan pertemuan bilateral. Hal ini juga menunjukan bahwa adanya upaya dialog antara kedua negara dari yang bersifat multilateral (melalui Six Party Talks) menjadi bilateral.

Pertemuan antara kedua negara ini diprediksi menjadi tiga skenario. ${ }^{116}$ Pertama, Korea Utara dan Amerika Serikat dapat mencapai kompromi maksimal jika Korea Utara mau memberhentikan uji coba serta pengembangan senjata nuklirnya dan Amerika Serikat juga bersedia mengurangi keterlibatan terhadap Korea Selatan. Dari sini, perdamaian antara Korea Utara dan Korea Selatan akan berhasil dan denuklirisasi akan terjadi di Semenanjung Korea. Skenario kedua ialah kompromi tidak penuh akan terjadi jika Amerika Serikat bersikukuh untuk mempertahankan keterlibatannya dalam urusan Korea Selatan, tetapi tentu saja

Amerika Serikat perlu membiarkan Tiongkok menjadi payung keamanan Korea

\footnotetext{
${ }^{114}$ Philip Zelikow. "How Diplomacy with North Korea Can Work”. 2018 : hlm. 3

${ }^{115}$ Simela Victor Muhammad. "Perdamaian di Semenanjung Korea Pasca Pertemuan Moon Jae In dan Kim Jong Un." Kajian Singkat terhadap Isu Aktual dan Strategis (Pusat Penelitian Badal Keahlian DPR RI), 2018. hlm. 2

${ }^{116}$ Chung Sung Yoon. "North Korea-U.S. Summit :Can It Become Crative Black Hole." Online Series, Maret 21, 2018: hlm.2
} 
Utara jika tetap ingin mencapai denuklirisasi dan meneruskan upaya damai Korea.

Dalam skenario ini juga terdapat dilema mengenai pihak mana yang nantinya akan melakukan inspeksi terhadap nuklir Korea Utara.

Skenario yang terakhir merupakan skenario paling buruk. Hal ini akan terjadi apabila Korea Utara dan Amerika Serikat mengalami kegagalan kompromi yang mana Korea Utara menolak proposal Amerika dan Amerika pun melakukan hal yang sama dengan proposal Korea Utara. ${ }^{117}$ Hal ini akan menyebabkan kemungkinan meningkatnya agresivitas Korea Utara dalam mengembangkan dan menguji coba senjata nuklir sehingga akan mengganggu keamanan internasional, khususnya di kawasan Asia Timur. Amerika Serikat juga akan dinilai sebagai negara yang membantu aliansinya untuk mencapai perdamaian.

Korea Utara telah lama meminta negosiasi secara bilateral dengan saling memahami, tetapi tidak ada yang bisa memprediksi bagaimana dinamika ini akan berlanjut. ${ }^{118}$ Jika pertemuan yang dilakukan gagal pun, Amerika Serikat telah membuktikan bahwa negaranya memang ingin mewujudkan denuklirisasi terhadap Korea Utara. Amerika Serikat juga memperlihatkan bahwa upaya yang dilakukannya bukan hanya bersifat koersif tetapi juga secara diplomatik. Upaya diplomatik pun tidak hanya dilakukan dalam forum multilateral tetapi juga bilateral yang mempertemukan kedua pemimpin negara.

Meskipun telah banyak Upaya Amerika Serikat yang diklaim untuk mewujudkan denuklirisasi, tetapi beberapa upaya justru makin membuat Korea

Utara menjadi semakin agresif dalam menguji coba nuklirnya. Upaya tersebut seperti penempatan USFK dan THAAD di Korea Selatan. kedua upaya ini justru

\footnotetext{
${ }^{117}$ Chung Sung Yoon. "North Korea-U.S. Summit :Can It Become Crative Black Hole." Online Series, Maret 21, 2018: hlm.2

${ }^{118}$ Philip Zelikow. hlm. 11
} 
membuat Korea Utara semakin agresif untuk melakukan pengembangan dan uji coba karena merasa diancam. Selain itu, Amerika Serikat juga hanya melibatkan Korea Utara secara langsung hanya dalam beberapa upaya, yaitu dalam forum Six Party Talks dan KTT Singapura 2018. ${ }^{119}$ Padahal keterlibatan Korea Utara dalam mewujudkan denuklirisasi adalah hal yang penting. Oleh karenaitu, sampai saat ini Korea Utara belum menemui titik memperlihatkan bahwa upaya denuklirisasi belum maksimal dilakukan.

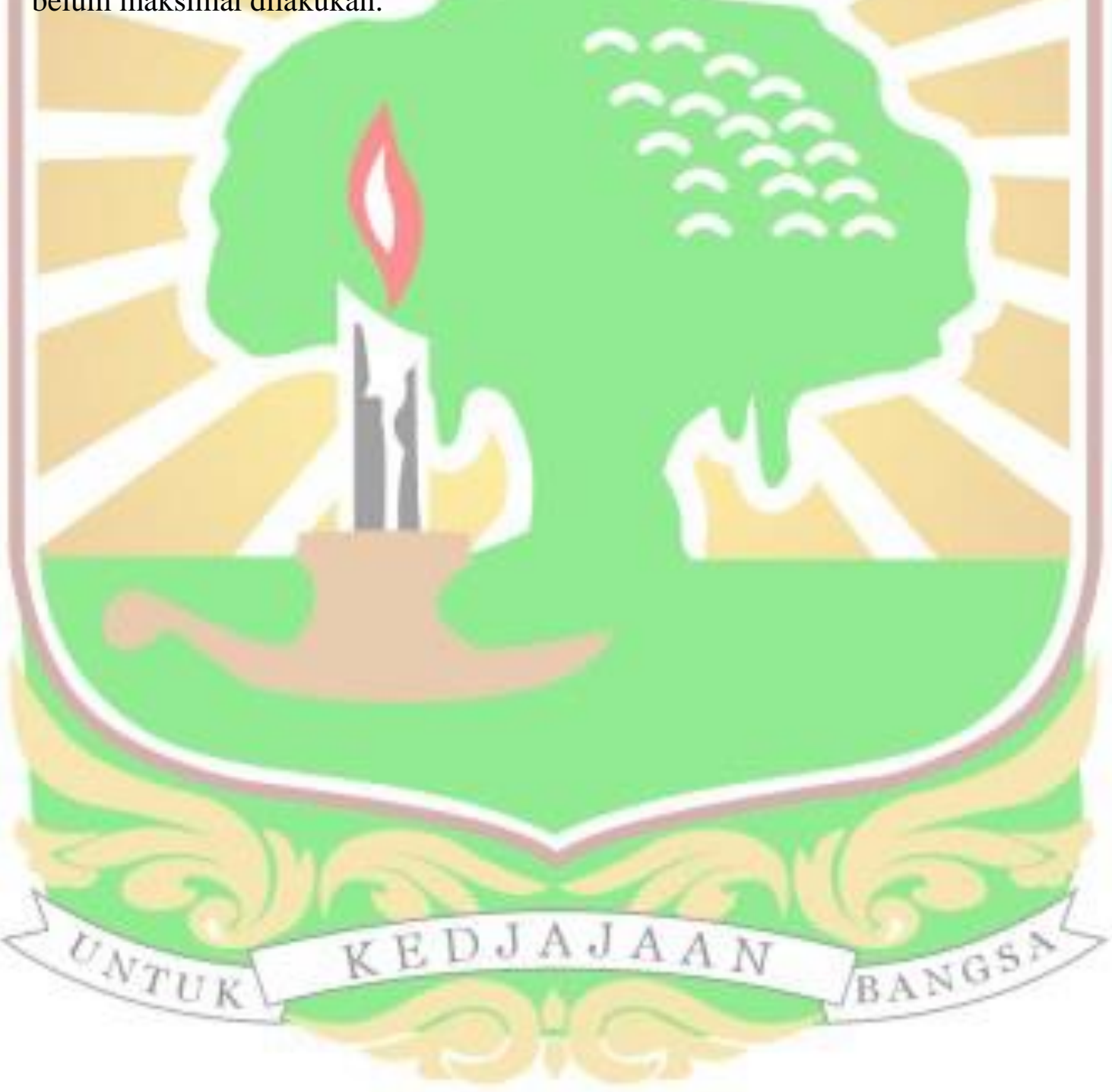

${ }^{119}$ BBC News Indonesia. Kim-Trump tandatangani 'kesepakatan' : Hubungan AS-Korut akan berbeda sama sekali. Diakses dari https://www.bbc.com/indonesia/amp/dunia-44447915 pada januari 2019 


\title{
BAB IV
}

\section{KEPENTINGAN AMERIKA SERIKAT DALAM PROSES \\ DENUKLIRISASI KOREA UTARA}

\begin{abstract}
Bab ini akan membahas mengenai kepentingan Amerika Serikat dalam proses denuklirisasi Korea Utara. Pada bab ini kepentingan Amerika Serikat akan dianalisis menggunakan konsep dari range of state interest milik Schweller. Namun, sebelum menganalisis kepentingan, peneliti menjelaskan mengenai hubungan Amerika Serikat dengan negara-negara di Asia Timur terlebih dahulu.
\end{abstract} Kemudian, Amerika juga terlebih dahulu diidentifikasi posisinya di sistem internasional melalui tindakannya.

\subsection{Hubungan Amerika Serikat dengan Negara di Kawasan Asia Timur}

Setelah Perang Korea, Perspektif Amerika Serikat tentang kawasan Asia telah berubah, terutama perspektif geografis dan politis di Semenanjung Korea. ${ }^{\mathbf{1 2 0}}$ Walaupun terdapat perdebatan mengenai bagaimana Semenanjung Korea dapat berdamai, tetapi hal yang perlu dipahami ialah bahwa Amerika Serikat merupakan aliansi Korea Selatan. Amerika Serikat tentu mempunyai pertimbangan yang serius tentang bagaimana bertindak dalam proses perdamaian Korea dan stabilitas keamanan Asia Timur. Bukan hanya itu, pihak yang berhasil membangun stabilitas keamanan di Semenanjung Korea tentunya layak untuk mendapat pujian dari internasional. ${ }^{121}$ Oleh karena itu, aktor-aktor lain (khususnya negara yang

\footnotetext{
${ }^{120}$ Hee Jea Lim. Korea is Really Matter to U.S.? The Relationship about USFK and ROK-U.S. Alliance. Halmstad University, 2011. Hlm. 4

${ }^{121}$ Edward A. Olsen. "Coping with the Korean Peace Process : An American View." The Korean Journal of Defense Analysis, 1997: hlm. 160
} 
terlibat dalam forum Six Party Talks) berurusan secara diplomatis maupun koersif untuk mewujudkan stabilitas keamanan tersebut.

Di sisi lain, nuklir Korea Utara dapat mengubah keseimbangan kekuatan Asia dan berkontribusi pada kebijakan Amerika Serikat di Asia. Hal itu menyebabkan Amerika Serikat juga perlu berpikir mengenai dampak apabila denuklirisasi terjadi maupun tidak terhadap Amerika Serikat dan kawasan Asia Timur. Sejauh ini, Amerika Serikat bertindak sebagai katalisator untuk perdamaian Korea. Oleh karena itu, Amerika Serikat dan Korea Selatan perlu membantu Korea Utara untuk merumuskan kembali nasionalisme Korea Utara. ${ }^{122}$

Walaupun Perang Dingin telah berakhir tetapi perang di wilayah kecil bisa dianggap sebagai konflik internal suatu negara sebenarnya adalah Perang politik kekuasaan antara demokrasi liberal dan komunisme. Hal tersebut merupakan fenomena yang masih terjadi di Semenanjung Korea. Ketegangan yang terjadi antara Korea Utara dengan negara tetangganya merupakan konflik yang sebenarnya masih dibayangi oleh fakta bahwa Korea Utara dan Korea Selatan belum resmi mengakhiri perang.. Oleh karena itu, Amerika Serikat terus terlibat di Semenanjung Korea, khususnya dalam upaya Denuklirisasi Korea Utara.

\subsubsection{Perjanjian Aliansi Amerika Serikat dan Korea Selatan}

Amerika Serikat telah mengikutsertakan diri dalam perpolitikan Korea terutama dikarenakan adanya Mutual Defense Treaty pada tahun 1954. ${ }^{123}$

Kesepakatan ini mengatur mengenai aliansi pertahanan bersama yang meliputi bantuan militer dan kesepakatan apabila salah satu negara diserang oleh pihak ketiga maka negara lain akan ikut bertindak. Korea Selatan pernah mendukung

\footnotetext{
${ }^{122}$ Edward A. Olsen. "Coping with the Korean Peace Process : An American View." Hlm. 163 ${ }^{123}$ Angga Aditama P. "Konflik di Semenanjung Korea dan Pengaruhnya terhadap Keamanan Internasional." (Universitas Gajah Mada) 2012: hlm. 9.
} 
Amerika Serikat dalam kampanye perangnya terhadap Vietnam dan Irak. Sejak saat itu, Amerika Serikat melakukan perlindungan terhadap Korea Selatan. ${ }^{124}$ Masyarakat Korea Selatan pun mengakui bahwa Amerika Serikat merupakan mitra keamanan yang paling penting karena telah memberikan perlindungan selama puluhan tahun. Berikut merupakan grafik respon masyarākat Korea Selatan mengenai negara mitra keamanan yang paling penting.

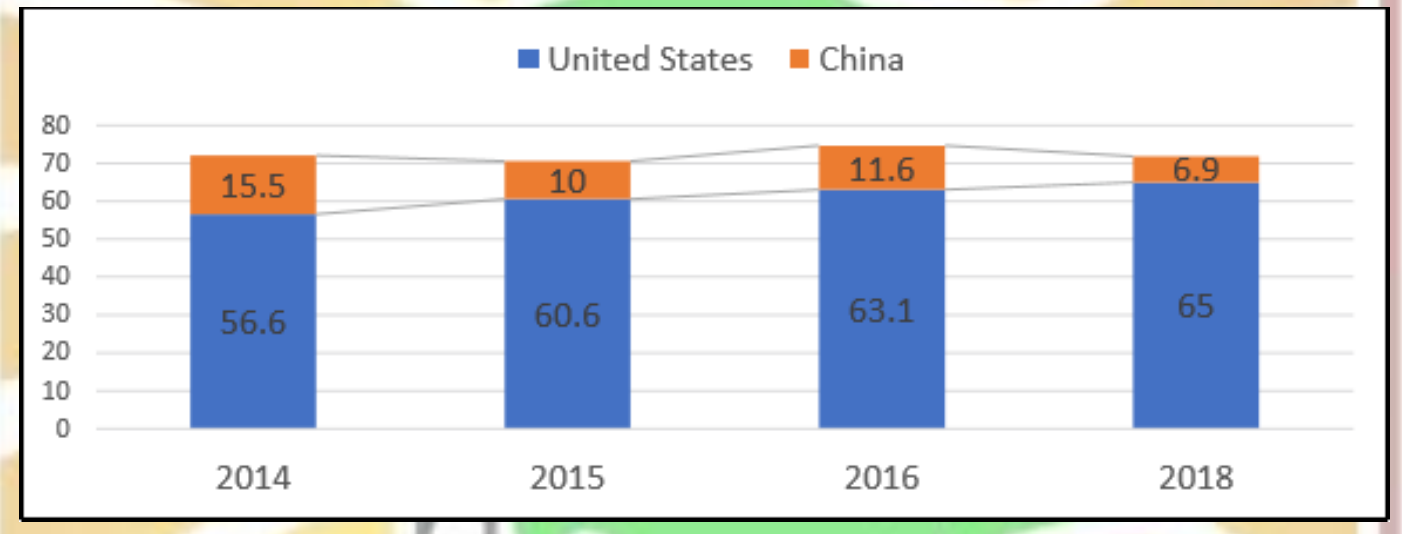

Respon Publik Korea Selatan terkait Mitra Keamanan paling Penting Sumber : U.S. as Most ImportantSecurity Partner for South Korea ${ }^{125}$

Gambar di atas menunjukan bahwa masyarakat Korea selatan cenderung lebih mengakui Amerika Serikat sebagai mitra keamanan yang paling penting bahkan dibandingkan Tiongkok yang merupakan negara Asia Timur. Terutama pada 2018, hanya $6,9 \%$ yang menganggap bahwa Tiongkok merupakan mitra keamanan yang lebih penting. Hal tersebut sangat kontras dengan jumlah masyarakat yang pro terhadap Amerika Serikat (65\%). Oleh karena itu, tidak

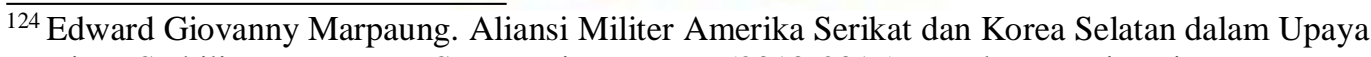
Menjaga Stabilitas Keamanan Semenanjung Korea (2010-2016). Bandung: Universitas Komputer Indonesia, 2017. Hlm. 2

${ }^{125}$ Yeseong Choi. U.S. Nuclear Strategy and North Korea's ICBM Capability : Changing South Korean Perceptions of U.S. Extended Detterence. Monterey : Naval Postgraduate School, 2018. Hlm. 57
} 
heran jika Korea Selatan sampai sekarang masih mengandalkan Amerika Serikat untuk menjaga stabilitas keamanan negaranya.

Korea Selatan yang rentan terhadap serangan dari Korea Utara membuat Amerika Serikat tidak diam saja dalam menanggapi tindakan Korea Utara yang cenderung ağresif. Sejak tahun 2004, Amerika Serikat meningkatkan kekuatannya di Korea Selatan melalui rotasi regular pesawat pemogokan tingkat lanjut. Angkatan bersenjata Korea Selatan berjumlah sekitar 630.000 tentara. Selain itu, Korea Selatan juga berada dalam lindungan payung nuklir Amerika Serikat. ${ }^{126}$ Pasukan USFK membantu untuk merespon uji coba nuklir Korea Utara pada $2009 . .^{127}$

Untuk menanggapi ancaman nuklir, Amerika Serikat juga sering melakukan latihan gabungan dengan Amerika Serikat. Contohnya pada 2013, Amerika Serikat langsung mengambil tindakan untuk latihan perang gabungan dengan Korea Selatan. Latihan perang gabungan antara kedua negara ini diberi nama Key Resolve and Foal Eagle. ${ }^{128}$ Pada latihan ini dilakukan berbagai macam taktik untuk mempertahankan stabilitas kemananan Semenanjung Korea.

Sebenarnya Korea Selatan dan Amerika telah mengalami konflik sejak awal aliansi meskipun Korea Selatan memang membutuhkan dukungan militer dan perekonomian. ${ }^{129}$ Meskipun aliansi Korea Selatan dan Amerika Serikat telah berlangsung lama, bukan berarti aliansi kedua negara tidak mengalami hambatan sama sekali. Hambatan yang pertama berkaitan dengan respon terhadap Korea

\footnotetext{
${ }^{126}$ Edward Giovanny Marpaung. AHlm 8

${ }^{127}$ Andrew Yeo. "U.S. Military Base Realignment in South Korea." Peace Review (Taylor\&Francis Group), 2010: Hlm. 118

${ }^{128}$ Thufeil Izharuddin. "Pengaruh Kebijakan Amerika Serikat di Semenanjung Korea dalam Proses Reunifikasi Korea (2011-2013)". Hlm. 43

${ }^{129}$ Hee Jea Lim. Hlm. 5
} 
Utara. Amerika Serikat cenderung melihat Korea Utara sebagai ancaman yang kuat sehingga cenderung melakukan kebijakan garis keras untuk membendung tindakan Korea Utara. Hal ini berbeda dengan Korea Utara yang cenderung melakukan pendekatan yang lebih hati-hati. Hal ini tidak terlepas dari fakta bahwa Korea Utara dan Korea Selatan berasal dari kesatuan yang sama.

Selain itu, terdapat gerakan anti Amerika Serikat di Korea Selatan. Namun, terlepas dari hambatan tersebut tujuan Aliansi militer Amerika Serikat- Korea Selatan akan bertahan ditandai dengan pernyataan komitmen dari setiap pemimpin kedua negara, khususnya Presiden Donald Trump yang telah mengumumkan komitmen ketatnya untuk mempertahankan aliansi militer dengan Korea Selatan.

\subsubsection{Hubungan Amerika Serikat dan Jepang}

Sejak kekalahan Jepang pada Perang Dunia II, Jepang akhirnya hanya memiliki SDF (Self Defense Forces) yang hanya diperbolehkan beroperasi di teritori Jepang. Kemudian, negara ini menjalin aliansi dengan Amerika Serikat yang diawali US-Japanese Security Treaty pada $1951 .{ }^{130}$ Namun, pada awalnya, penandatanganan ini dilakukan secara 'terpaksa' karena setelah kekalahan perang, Jepang memang mengalami kehancuran dan dalam perjanjian, Amerika Serikat akan ditempatkan di Jepang. Dengan pasukan Amerika Serikat berada di wilayahnya, Jepang tentu tidak bebas bertindak sehingga Pemerintah Nobusuke Kishi meminta revisi perjanjian. ${ }^{13}$

Namun, penempatan pasukan ini di sisi lain memberikan mafaat untuk melindungi dan menjaga keamanan Jepang secara berkelanjutan. Skema

\footnotetext{
${ }^{130}$ Michael J. Green. "The US-Japan Alliance : A Brief History”. Asian Governments and Legal System. Vol.12 No.3 . 2007 : hlm. 26

${ }^{131}$ Michael J. Green. hlm. 26
} 
kerjasama keamanan antara kedua negara ini diatur dalam Japan-US Defense

Guidelines. Kerjasama keamanan ini membantu mendorong Jepang untuk memulihkan kembali sistem pemerintahannya. Dengan sistem pertahanan yang telah pulih, Jepang pun dapat mengembangkan kembali teknologi dan perekonomiannya. IVERSTTAS ANDALAS

Setelah berhasil memulihkan perekonomiannya, Jepang harus menerima kenyataan bahwa perjanjian aliansi juga berarti bahwa Jepang harus memberikan bantuan kepada Amerika Serikat. Oleh karena itu, Jepang juga terlibat untuk mendukung Amerika Serikat dalam Perang melawan Vietnam pada 1968. ${ }^{132} \mathrm{Hal}$ ini membuat Jepang terus berupaya menggandakan anggaran pertahanannya. Bahkan, dikarenakan perlawanan Vietnam yang kuat, Jepang juga sempat mempertimbangkan untuk mengembangkan senjata nuklir walaupun akhirnya rencana ini tidak terwujud.

Walaupun Jepang telah memiliki 310.457 personil militer, 1.500 pesawat tempur, 679 tank, 131 aset laut (36 kapal penghancur, 17 kapal selam, dan asset laut lainnya). ${ }^{133}$ Namun, sampai saat ini, Jepang masih berlindung di bawah Payung Militer Amerika Serikat. Hal ini dikarenakan Amerika Serikat masih lebih unggul dalam hal jumlah. Menurut Global Firepower 2018, Amerika Serikat memiliki lebih dari 2 juta personil militer, 13.362 pesawat, 5.884 tank, dan 415 aset laut. ${ }^{134}$ Selain itu, Amerika Serikat juga memiliki 686 pangkalan militer di luar negara bagian Amerika Serikat termasuk Jepang.

\footnotetext{
132 Michael J. Green. hlm. 26

${ }^{133}$ Meidy Amanda. "Dilema Aliansi Amerika Serikat terkait Peningkatan Kapabilitas Militer Jepang." Jurnal Ilmu Sosial dan Ilmu Politik (Universitas Indonesia) 1 (2018): Hlm.164

${ }^{134}$ Meidy Amanda. Hlm. 164
} 
Secara geografis, Jepang merupakan negara yang dekat dengan Tiongkok dan Korea Utara. Kedua negara ini terus melakukan peningkatan kemampuan militernya dari tahun ke tahun. Belum lagi, mengingat kedua negara ini memiliki program pengembangan senjata nuklir. Permasalahannya ialah hubungan di antara negara ini cenderung diwarnai oleh konflik sehingga peningkatan kapabilitas pertahanan Tiongkok dan Korea Utara tentu mengancam Jepang.

Oleh karena itu, Amerika Serikat membantu Jepang dalam latihan gabungan bersama untuk menanggapi ancaman yang ada di kawasan Asia Timur. Pada tahun 2017, Jepang melakukan latihan besar-besaran di laut, darat, dan udara. Latihan perang angkatan laut gabungan melibatkan 14.000 tentara Amerika Serikat, kapal induk USS Ronal Reagan dan tiga kapal perang di Okinawa. Pasukan Udara Jepang (ASDF) juga melakukan latihan gabungan dengan melibatkan dua pesawat pengebom B-1B milik Angkatan Udara Amerika Serikat ${ }^{135}$. Bukan hanya itu, Jepang juga akan memiliki rudal jelajah jarak jauh atas bantuan Amerika Serikat.

Seperti hubungan aliansi lainnya, Hubungan aliansi antara Jepang dan Amerika Serikat juga mengalami pasang surut. Namun, sejauh ini, hubungan kedua negara ini berjalan dengan baik. ${ }^{136}$ Walaupun terkadang masing-masing negara memiliki kepentingan dan pandangan yang berbeda, tetapi keduanya saling membutuhkan untuk menyelesaikan permasalahan, terutama yang berkaitan dengan keamanan nasional. Hal ini juga membuat Jepang tidak hanya bersikap pasif dalam pertahanannya $K$ karena ketika Amerika Serikat membutuhkan dukungan pertahanan, Jepang juga mengikutsertakan kapabilitas militernya.

135 Meidy Amanda. hlm. 161.

${ }^{136}$ Michael J. Green. hlm. 30 


\subsubsection{Rivalitas Amerika Serikat dan Tiongkok}

Kebangkitan Tiongkok membuat Amerika Serikat bukanlah satu-satunya negara yang memiliki pengaruh besar di kawasan Asia Timur. Persepsi persaingan terhadap Tiongkok telah berkembang sejak Amerika Serikat memberlakukan 'Pivot to Asia'. Hal ini mënggoyahkan pernyataan bahwa/setelah terjadinya Perang Dingin, maka tidak ada lagi negara musuh Amerika Serikat yang mampu menyaingi kekuatannya. ${ }^{137}$ Di bidang keamanan, Amerika Serikat dan Tiongkok akan semakin kompetitif melalui isu-isu Korea Utara dan Program pengembangan senjata nuklirnya. Amerika Serikat dan Tiongkok adalah dua variabel luar utama yang mempengaruhi geopolitik Korea.

Dalam menganalisis hubungan antara kedua negara ini, para ahli melihat tiga faktor yang meliputi hubungan perdagangan yang saling ketergantungan, hubungan pribadi antara pemimpin, dan persepsi antara masyarakat di kedua negara. Perlu dipahami bahwa hubungan antara pemimpin kedua negara juga dipengaruhi oleh mandat historis. Dalam bidang militer, Tiongkok dinilai masih lemah dibandingkan Amerika Serikat.

Amerika Serikat dan Tiongkok menandatangani Pernyataan bersama saat kunjungan Presiden Barrack Obama ke Tiongkok pada November 2009. Pernyataan bersama ini merupakan komitmen untuk memajukan hubungan Tiongkok dan Amerika Serikat di era baru. ${ }_{1}^{138}$ Namun, hal ini menjadi buruk saat penjatuhan sanksi-sanksi lekonomi secara berturut-turut oleh Amerika Serikat terhadap

Tiongkok. Beberapa bulan kemudian, Barrack Obama melakukan

\footnotetext{
${ }^{137}$ Seong-Hyon Lee. "The Shift of Security Environment in Northeast Asia : The U.S. China Conflict and Its Implications for Korea." Journal for Peace and Nuclear Disarmament, 2018: hlm.6

${ }^{138}$ Yan Xuetong. "The Instability of China-US Relations". The Chinese Journal of International Politics. Vol.3. 2010: hlm. 263
} 
kunjungan kembali pada Februari 2010. Kemudian, pada April 2010, kedua negara menyatakan telah melakukan pemulihan hubungan melalui sambungan telepon

US-China Comprehensive Economic Dialogue yang telah diluncurkan pada masa Obama, seakan 'ditinggalkan' pada masa pemerintahan Donald Trump. Pada awal tahun 2018, Trump dinilai telah memprovokasi Perang Dagang terhadap Tiongkok. Amerika Serikat menjatuhkan hukuman pada impor baja dan alumunium. ${ }^{139}$ Tetapi Trump tetap melakukan kunjungan dan pembicaraan dengan Tiongkok terkait denuklirisasi Korea Utara. ${ }^{140}$

Walaupun Amerika dan Tiongkok memiliki hubungan yang tidak tetap, tapi kedua negara ini memiliki beberapa kesamaan kepentingan dalam bidang ekonomi, politik, dan keamanan. Dalam bidanng keamanan, Amerika Serikat dan Tiongkok sama-sama memiliki kepentingan dalam hal denuklirisasi Korea Utara. ${ }^{141}$ Hal ini dikarenakan nuklir Korea Utara menimbulkan ancaman terhadap stabilitas kawasan. Selain itu, Di bidang politik, Amerika Serikat dan Tiongkok pun samasama anggota tetap UNSC (United Nations Security Council). Oleh karena itu, Tiongkok terkadang masih menegaskan komitmen berkelanjutannya terhadap sanksi ekonomi PBB terhadap Korea Utara walaupun secara hati-hati. ${ }^{142}$

Walaupun sama-sama memiliki kepentingan dalam hal denuklirisasi, terkadang Tiongkok tidak setuju dengan tindakan Amerika Serikat untuk mewujudkan denuklirisasi. Salah satunya adalah Tiongkok menganggap bahwa penempatan THAAD di Korea Selatan hanya sebagai alasan Amerika Serikat

\footnotetext{
${ }^{139}$ Jhon Peterson. "Structure, Agency, and Transatlantic Relations in the Trump Era". Journal of European Intergration. Vol.40 : 5. 2018 : 641

${ }^{140}$ Jhon Peterson. hlm. 42

141 Yan Xuetong. Hlm. 274

${ }^{142}$ Seong-Hyon Lee. hlm.3
} 
untuk mengawasi Tiongkok. Menteri Luar Negeri Tiongkok, Wang Yi telah menyebutkan setidaknya 50 kali retorika mengenai penolakan terhadap THAAD. ${ }^{143}$ Hal ini dikarenakan pemasangan radar THAAD di Jepang $1.000 \mathrm{~km}$ letaknya dari perbatasan Tiongkok. Dengan begitu, Tiongkok khawatir jika penempatan THAAD di Korea Selatan jugga dapat mengancam Tiongkok. Oleh kârena itu, Tiongkok menunjukan ketidaksenangannya terhadap sikap Korea Selatan yang menerima penempatan THAAD dengan cara langsung memberikan sanksi terhadap bidang hiburan Korea Selatan di Tiongkok. Tiongkok juga mengambil langkah untuk melakukan kerjasama dengan Rusia terkait pertahanan misil sebagai respon terhadap THAAD. ${ }^{144}$

Dari bulan maret hingga Juni, Xi Jin Ping selaku pemimpin Tiongkok menemui Kim Jong Un tiga kali. Dalam pertemuan itu, Xi berjanji pada Korea Utara bahwa Tiongkok akan tetap mendukung Korea Utara, masyarakat Tiongkok pun menerima Korea Utara, serta Tiongkok akan mendukung ‘Sosialisme Korea Utara'. Sebaliknya, Amerika Serikat justru menawarkan kesejahteraan untuk Korea Utara apabila Korea Utara benar-benar melakukan denuklirisasi.

Dalam Forum Ekonomi Timur di Rusia pada 2018, Tiongkok mengisyaratkan mengenai dukungan terhadap Deklarasi Perdamaian Trilateral untuk mengakhiri Perang Korea. Amerika Serikat dianggap enggan untuk membahas deklarasi akhir Perang Korea dikarenakan keberadaan Tiongkok. ${ }^{145}$

Namun, perlu dipahami Tiongkok juga memiliki kepentingan geopolitik yang muncul ketika Amerika Serikat menempatkan USFK di Korea Selatan. Dari

\footnotetext{
${ }^{143}$ Farel Akbar Bramantya. hlm. 3

${ }^{144}$ Rinna, Anthony V. "Russia's Strategic Partnership with China and Soth Korea : The Impact of THAAD." Asia Policy 13 (2018): hlm. 80

${ }^{145}$ Seong-Hyon Lee. hlm.2
} 
pemaparan di atas, dapat dilihat bahwa Amerika Serikat an Tiongkok memang memiliki kepentingan untuk denuklirisasi Korea Utara, tetapi hubungan kedua negara ini cenderung naik turun karena adanya hubungan rivalitas di bidang keamanan maupun ekonomi.

\subsubsection{Korea Utara dalam Pandangan Amerika Serikat}

Dalam pandangan Amerika Serikat, Korea Utara dinilai sebagai negara yang agresif dikarenakan pengembangan dan uji coba senjata nuklir. Meskipun telah diberikan sanksi keuangan dan diberikan kecaman, Korea Utara tetap mengembangkan senjata nuklirnya. Amerika Serikat juga menganggap bahwa Korea Utara merupakan aliansi penting dari Tiongkok. Berikut ini merupakan kapabilitas senjata nuklir Korea Utara.

Tabel

\section{Kapabilitas Nuklir Korea Utara}

\begin{tabular}{|l|c|c|c|c|}
\hline & Taepo Dong-2 & $\begin{array}{c}\text { Hwasong- } \\
13\end{array}$ & $\begin{array}{c}\text { Hwasong- } \\
14\end{array}$ & $\begin{array}{c}\text { Hwasong- } \\
15\end{array}$ \\
\hline Jumlah & 3 & 3 & 2 & 2 \\
\hline jenis bahan bakar & Cair & Cair & Cair & Cair \\
\hline Mode Pengembangan & Fixed & $\begin{array}{c}\text { Road } \\
\text { Mobile }\end{array}$ & $\begin{array}{c}\text { Road } \\
\text { Mobile }\end{array}$ & $\begin{array}{c}\text { Road } \\
\text { Mobile }\end{array}$ \\
\hline $\begin{array}{l}\text { jarak tempuh } \\
\text { maksimum }\end{array}$ & $12.000+$ & 11.500 & 10.400 & 13.000 \\
\hline $\begin{array}{l}13 / 4 / 2012 \text { dan } \\
\text { tahun uji coba }\end{array}$ & $\begin{array}{c}\text { belum di } \\
\text { tahun dikembangkan }\end{array}$ & $2012 / 2012$ & \multicolumn{2}{|c|}{ dalam pengembangan } \\
\hline
\end{tabular}

Sumber : North Korean Nuclear Capability ${ }^{146}$

Tábel di atas memperlihatkan pengembangan missil Korea Utara telah

memiliki jarak tempuh yang bervariasi. Jarak tempuh paling pendek mencapai sekitar 10.000 km. Sedangkan Hwasong-15 telah memiliki jarak tempuh kira-kira

\footnotetext{
${ }^{146}$ Yeseong Choi. U.S. Nuclear Strategy and North Korea's ICBM Capability : Changing South Korean Perceptions of U.S. Extended Detterence. Monterey. HIm. 89
} 
$13.000 \mathrm{~km}$. Sementara dalam hal uji coba, tipe Taepo Dong-2 telah di uji coba pada tahun 2012, Hwasong-14 dan Hwasong-15 di uji coba pada 2017. Tipe Hwasong sebenarnya masih dalam tahap pengembangan, tidak menutup kemungkinan bahwa kapabilitas nukllir ini akan terus meningkat kedepannya. Barack Obama sendiri pernahmenyatakan bahwa Amerika Serikat tidak akan pernah menerima Korea Utara sebagai negara pemilik senjata nuklir. Negara ini dianggap membawa isolasi dan kemiskinan bagi rakyatnya melalui upaya untuk mencapai kapabilitas senjata nuklir dan rudal balistik. ${ }^{147}$ Bagi Obama, Korea Utara akan segera runtuh jika tidak berupaya untuk menghentikan pengembangan senjata nuklir yang memakan biaya dalam jumlah banyak. Keadaan Korea Utara diperburuk dengan kesulitan politik dan permasalahan ketersediaan pangan. ${ }^{148}$ Oleh karena itu, Amerika Serikat di bawah pemerintahan Obama lebih melakukan pendekatan yang 'menunggu' Korea Utara untuk bernegosiasi dalam forum Six Party Talks. ${ }^{149}$

Di bawah kepemimpinan Trump, Korea Utara masih dipandang sebagai negara yang irrasional. Namun, agresivitas Korea Utara yang semakin meningkat membuat Donald Trump meninggalkan pendekatan Amerika Serikat pada periode sebelumnya. Donald Trump beranggapan bahwa Korea Utara perlu di respon secara lebih tegas. Oleh karena itu, Amerika Serikat pada tahun 2017 berencana akan menggerakan aksi militer secara besar-besaran melalui Jim Mattis. ${ }^{150}$ Namun, pemerintahan Trump pun melakukan pendekatan diplomasi bilateral

\footnotetext{
${ }^{147}$ Krisandhy Ertanto Rantung. hlm.1

${ }^{148}$ Edward A. Olsen. "Coping with the Korean Peace Process : An American View." The Korean Journal of Defense Analysis, 1997: Hlm. 159

${ }^{149}$ Emma Chanlett-Avery, dkk. "North Korea : U.S. Relations, Nuclear Diplomacy, and Internal Situation". Congressional Research Service. 2015 : hlm. 6

${ }^{150}$ CNN Indonesia. "Respon Nuklir Korea Utara, AS Ancam Aksi Militer Skala Besar". 4 September 2017. Diakses dari https://m.cnnindonesia.com/internasional/201709033233257-113239201/respon-nuklir-korea-utara-as-ancam-militer-skala-besar pada 1 Desember 2019
} 
dengan Korea Utara karena mengancam secara terus-menerus bisa memunculkan perang yang sesungguhnya.

\subsection{Amerika Serikat sebagai Status Quo State}

Amerika Serikat tidak akan dapat mendominasi kawasan Asia Timur tanpa mengeluarkan cost setelah berakhirnya Perang Dingin. ${ }^{151}$ Oleh karena itu, Amerika Serikat tetap melakukan tindakan atau upaya yang menjaga posisinya di Asia Timur. Adapun tindakan Amerika Serikat cenderung mengarah kepada balancing.

Selain itu, Amerika Serikat dinilai oleh para ahli sebagai negara yang berupaya untuk mempertahankan sistem yang telah ada. Amerika Serikat juga ingin mempertahankan posisi sebagai negara Super power (peringkat paling atas dalam sistem). Hal-hal tersebut menandakan bahwa Amerika Serikat merupakan Status Quo State.

\subsubsection{Amerika Serikat sebagai first rank}

Setelah berakhirnya Perang Dingin, Amerika Serikat menjadi negara yang paling mendominasi sistem internasional. Di bidang militer, negara ini menduduki posisi pertama di dunia sebagai negara dengan kekuatan militer terkuat. Berikut merupakan 10 negara dengan kekuatan militer terkuat di dunia menurut Global Firepower :

\section{Tabel 4.2}

\begin{tabular}{|c|c|c|}
\multicolumn{3}{|c|}{ Posisi negara kekuatan militer terkuat di dunia } \\
\hline Posisi & Negara & Index kekuatan militer* \\
\hline 1 & Amerika Serikat & 0,0615 \\
\hline
\end{tabular}

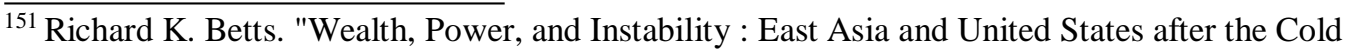
War." International Security (The MIT Press) 18 (1993-1994): hlm. 36
} 


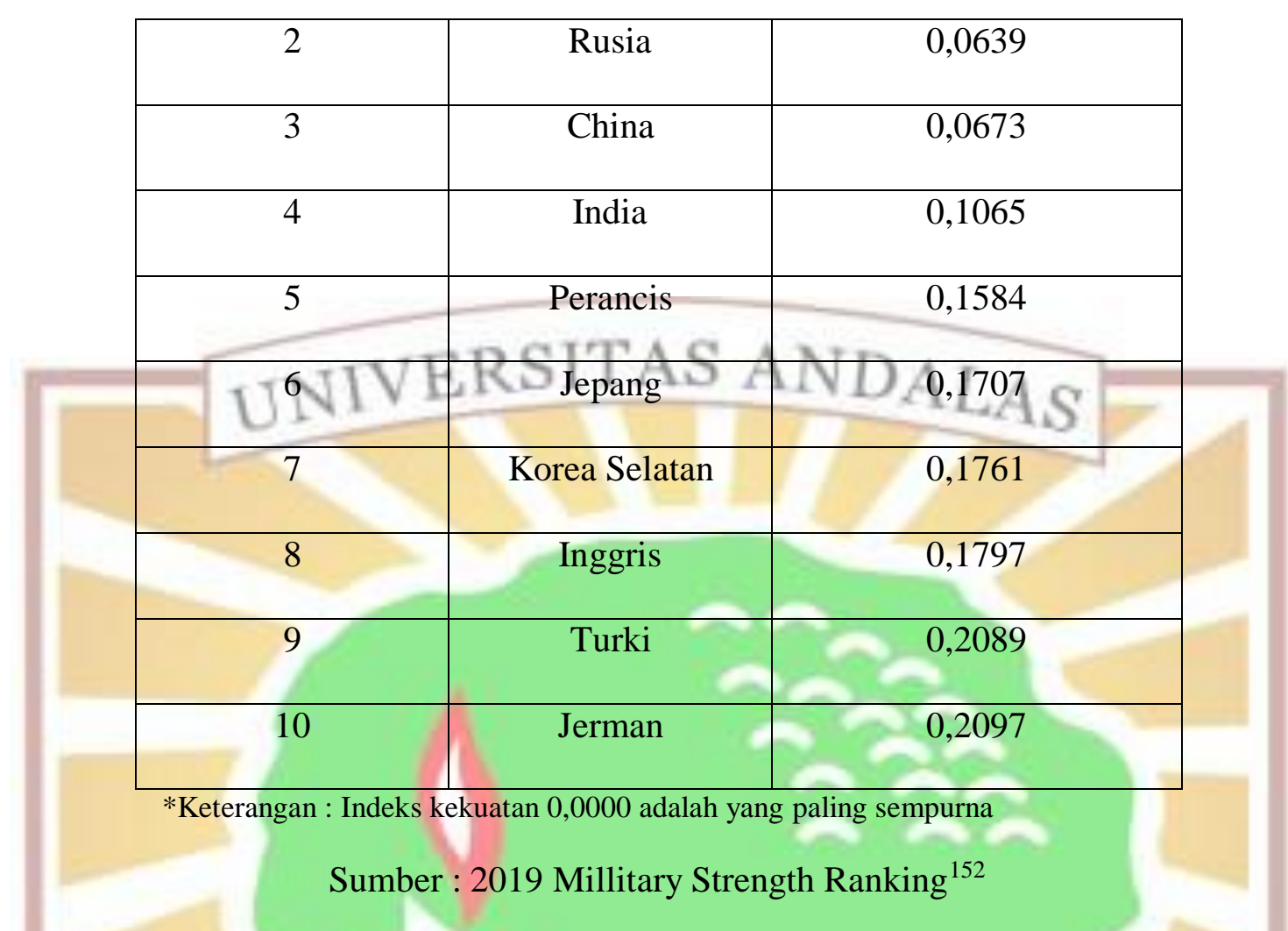

Dari tabel di atas dapat dilihat bahwa Amerika Serikat merupakan pemangku posisi pertama dengan indeks kekuatan 0,0615. Posisi yang ditetapkan oleh GFP (Global Fire Power) tersebut dilihat dari beberapa faktor yaitu manpower, airpower, kekuatan angkatan darat, angkatan laut, dan logistic lainnya. Amerika Serikat sendiri memiliki total personel aktif sebanyak 2.141.900 orang, 13.398 total kekuatan udara, 6.287 tank dan sekitar 41.000 kekuatan darat lainnya, 415 total asset angkatan laut, dan anggaran militer sejumlah $\$ 716.000 .000 .000 .{ }^{153}$ Selain dari kekuatan militer, Amerika Serikat juga merupakan negara core. ${ }^{154}$ Dalam hal ini, Amerika Serikat telah mampu menciptakan inovasi untuk kegiatan ekonomi. Negara ini juga merupakan posisi pertama dalam kekuatan

\footnotetext{
${ }^{152}$ Global FirePower 2019. "2019 Military Strength Ranking”. Diakses dari https://www.globalfirepower.com pada 10 Desember 2019

${ }^{153}$ Global FirePower 2019. "United States Military Strength". Diakses dari https://www.globalfirepower.com pada 10 Desember 2019

${ }^{154}$ Rob Clark dan Jason Beckfield. "A New Trichotomus Measure of World System Position Using the International Trade Network". International Journal of Comparative sociology. SAGE Publication. 2016: hlm. 17
} 
perekonomian dunia. berikut ini merupakan 10 negara dengan peringkat GDP

(Gross Domestic Product) teratas menurut World Bank :

Tabel 4.3

Negara-Negara Posisi Perekonomian Teratas

\begin{tabular}{|c|c|c|}
\hline Posisi & UN Negara RS I & GDP (dalam juta Dolâr Amerika Serikat) \\
\hline 1 & Amerika Serikat & 20.494 .100 \\
\hline 2 & Tiongkok & 13.608 .152 \\
\hline 3 & Jepang & 4.970 .916 \\
\hline 4 & Jerman & 3.996 .759 \\
\hline 5 & Inggris & 2.825 .208 \\
\hline 6 & Perancis & 2.777 .535 \\
\hline 7 & India & 2.726 .323 \\
\hline 8 & Italia & 2.073 .902 \\
\hline 9 & Brazil & 1.868 .626 \\
\hline 10 & Kanada & 1.712 .510 \\
\hline & Sumbr & \\
\hline
\end{tabular}

Sumber : Gross Domestic Product $2018^{155}$

Tabel di atas menunjukan bahwa Amerika Serikat merupakan negara yang paling kuat di bidang perekonomian dengan GDP \$20.494.100 juta. Sementara itu, hanya Tiongkok dan Jepang negara Asia Timur yang menduduki 10 posisi teratas. Dengan kekuatan ekonomi dan militer terkuat di dunia, Amerika Serikat tentu menjadi negara first rank dalam sistem internasional.

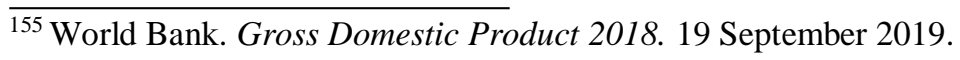




\subsubsection{Tindakan Amerika Serikat sebagai Status Quo State}

Sebagai status Quo state, Amerika Serikat cenderung melakukan tindakan balancing atau buck passing. Balancing adalah tindakan dari negara yang menyatakan bahwa nilai yang telah mereka miliki lebih dari nilai yang mereka dambakan. ${ }^{156}$ Dikarēnakan balancing merupakan tindakan yang memerlukan cost yang tidak sedikit, maka tindakan ini diambil oleh negara yang cenderung kuat. ${ }^{157}$

Hal yang perlu diingat, bahwa balancing tidak dilakukan untuk menyeimbangi negara kuat, tetapi lebih kepada negara yang berpotensi sebagai aggressor. ${ }^{158}$ Amerika Serikat sebagai negara yang ingin mempertahankan nilai yang mereka miliki tentu bisa melakukan tindakan ini, khususnya dalam merespon agresivitas dari Korea Utara. Sedangkan, Buck passing merupakan strategi suatu negara untuk mencegah agressor dengan memanfaatkan negara lain sementara negara ini tetap mematuhi pedoman.

Beberapa tindakan Amerika Serikat dalam kasus denuklirisasi Korea Utara cenderung melakukan tindakan balancing. Amerika Serikat menerapkan kebijakan rebalancing yang difokuskan ke Asia pasifik. ${ }^{159}$ USFK dan berbagai latihan gabungan adalah inti upaya dari Amerika Serikat dan Korea Selatan untuk menjaga perdamaian di Semenanjung Korea. Hal ini juga ditujukan untuk mengimplementasikan peran 'balancer' di Asia Timur. ${ }^{160}$ Dari sini dapat dilihat bahwa Amerika Serikat melakukan upaya Balancing di Asia Timur untuk mengatasi ancaman Korea Utara. Pemerintah Amerika Serikat juga menggunakan

\footnotetext{
156 Thomas Gangale. "Alliance Theory : Balancing, Bandwagoning, and Detente". Hlm. 17

${ }^{157}$ Randall L. Schweller. 'New Realist Research on Alliance : Refining, not Refuting, Walt'z Balancing Preposition". hlm.928

158 Thomas Gangale. Hlm. 17

${ }^{159}$ Vanilla Planifolia. "Strategi Rebalancing Amerika Serikat di Kawasan Asia Pasifik." Jurnal Hubungan Internasional, 2017:Hlm. 145

${ }^{160}$ Hee Jea Lim. Hlm. 17
} 
Pivot to Asia sebagai upaya rebalancing pada tahun 2009. ${ }^{161}$ Meskipun strategi ini bukan hanya untuk merespon nuklir Korea Utara, tetapi denuklirisasi merupakan salah satu tujuan yang hendak dicapai oleh Amerika Serikat di Asia Pasifik.

Dalam kasus THAAD, Amerika Serikat masih melakukan tindakan THAAD, walaupun sasarannya bukan hanya Korea Utara. Walaupun Amerika Serikat menyatakan bahwa penempatan THAAD di Korea Selatan hanya untuk menghindarkan Korea Selatan dari ancaman nuklir Korea Utara, tetapi tindakan ini dinilai sebagai tindakan balancing Amerika Serikat terhadap Tiongkok. ${ }^{162}$ Penempatan THAAD ini dianggap sebagai salah satu upaya Amerika Serikat yang bertujuan untuk menekan Korea Utara juga disebut-sebut untuk mengawasi pergerakan Tiongkok. Pertemuan bilateral antara Donald Trump dan Kim Jong Un juga merupakan salah satu bentuk tindakan balancing dalam proses denuklirisasi Korea Utara.

Sementara itu, Pembuatan UNSCR pada 2009 dan 2013 dapat dikategorikan sebagai tindakan buckpassing karena Amerika Serikat mendorong negara lain agar melawan pengembangan senjata nuklir Korea Utara dengan cara tidak memberikan fasilitas dan kebutuhan pangan kepada Korea Utara. Dalam hal ini, Amerika Serikat tetap mematuhi pedoman untuk menjaga perdamaian dengan menghindari perang tetapi mencoba membuat negara lain ikut mencegah agresor (Korea Utara).

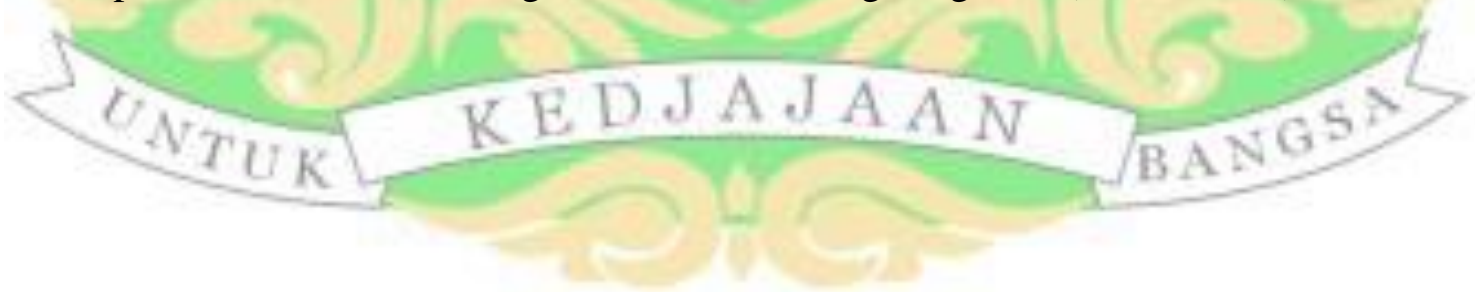

\footnotetext{
${ }^{161}$ Kurt Campbell da Brian Andrews. "Explaining the US 'Pivot to Asia'". London : Catham House. 2013 : hlm. 2

${ }^{162}$ Farel Akbar Bramantya. hlm. 6
} 


\subsubsection{Amerika Serikat sebagai Negara 'Lion'}

Menurut Schweller dalam range of state interest, Lion dicirikan sebagai negara yang menduduki 'first rank'. ${ }^{163}$ Negara ini dinilai sebagai negara dengan posisi atas di sistem internasional. Negara tersebut juga merupakan negara yang sangat puas dengan sistem yang telah ada. Hal ini dikarenakan negara ini menerima manfaat yang besar dari sistem yang sebenarnya telah ia kelola. Selain itu, negara Lion juga merupakan negara yang mengambil tindakan balancing atau buckpassing untuk menghadapi ancaman.

Amerika Serikat merupakan pemangku posisi teringgi di sistem internasional pada saat ini. Amerika pun (dalam kasus denuklirisasi) menggunakan tindakan balancing untuk menghadapi agresivitas Korea Utara. Oleh karena itu, dapat dilihat bahwa Amerika Serikat merupakan negara dalam range Lion. Amerika Serikat selama ini telah menerima keuntungan dari posisinya di sistem internasional sehingga ia berupaya untuk mempertahankan kondisi atau sistem yang ada.

\subsection{Korea Utara Sebagai Negara 'Wolves'}

Pengembangan nuklir yang dilakukan oleh non-negara pemilik nuklir memang selalu menyita perhatian. ${ }^{164}$ Banyak yang berpendapat bahwa Korea Utara merupakan negara negara agresif dan irrasional karena telah mengembangkan dan menguji senjata nuklir beberapa kali, Pengembangan nuklir Korea Utara sendiri sebenarnya didorong oleh ancaman nuklir yang diberikan

\footnotetext{
${ }^{163}$ Randall L. Schweller. "Bandwagoning for Profit : Bringing the Revisionist State Back In". Hlm. 85

${ }^{164}$ Inda Mustika Permata. "Analisis Konstruktivisme : Perilaku Korea Utara terhadap Denuklirisasi”. Andalas Journal of International Studies. Vol.7, No.2. 2018 : Hlm. 105
} 
oleh Amerika Serikat kepada Korea Selatan untuk menghentikan tindakan Korea Utara pada 1950 -an. ${ }^{165}$

Sejak saat itu, para pemimpin Korea Utara percaya bahwa dengan nuklir, posisi negaranya akan berubah. Setelah bertahun-tahun mengamati perilaku Korea Utara, banyảk analis yang melihat bahwa tuntutan Korea Utara hanyalah taktik untuk mendapatkan imbalan dan pengakuan tanpa berniat menghentikan pengembangan nuklir. ${ }^{166}$ Nampaknya, para pemimpin Korea Utara percaya bahwa tanpa senjata nuklir, negaranya akan mudah untuk digulingkan oleh pemberontak yang dibantu intervensi militer luar. Tanpa nuklir, negara ini juga akan tetap menjadi negara 'lemah' di sistem internasional.

Dalam bab II, telah dijelaskan bahwa Korea Utara merupakan negara yang tidak puas terhadap sistem yang telah ada sehingga berkeinginan untuk melakukan perubahan. Hal ini menunjukan bahwa Korea Utara merupakan Revisionist State. Sementara itu, Dalam range of state interest, negara yang memiliki tindakan agresif adalah negara dalam range Wolves. Negara ini memiliki tujuan tak terbatas dalam pengambilan tindakannya. Negara ini sangat menginginkan nilai yang didambakannya dengan cara melakukan tindakan agresi.

Korea Utara merupakan negara yang menentang keberadaan Amerika Serikat di Asia Timur. ${ }^{167}$ Namun, Amerika Serikat justru merupakan negara yang memiliki dominasi kuat di Asia Timur. Selain itu, tidak mungkin Amerika Serikat membiarkan aliansinya (Jepang dan Korea Selatan) terancam oleh pihak lain.

Sebagai bentuk perlawanan Korea Utara atas keberadaan Amerika Serikat di Asia

\footnotetext{
${ }^{165}$ Inda Mustika Permata. Hlm. 107

${ }^{166}$ Emma Chanlett-Avery, dkk. Hlm. 8

${ }^{167}$ Thufeil Izharuddin. "Pengaruh Kebijakan Amerika Serikat di Semenanjung Korea dalam Proses Reunifikasi Korea (2011-2013)”. Jakarta : UIN Syarif Hidayatullah . 2016: hlm. 38
} 
Timur, maka Korea Utara mengembangkan senjata nuklirnya. Korea Utara bukan hanya mengembangkan tetapi juga melakukan tindakan yang cenderung beresiko agresi yaitu dengan menguji coba misil beberapa kali si Semenanjung Korea.

\subsection{Kepentingan Amerika Serikat sebagai Lion State}

Setelah berakhirnya Perang Dunia II, tujuan dasar keamanan nasional Amerika Serikat adalah pengaruh global, yaitu memperoleh dan mempertahankan supremasi. ${ }^{168}$ Tujuan dasar untuk Amerika Serikat adalah untuk 'preserve' dalam posisinya di dunia internasional. Jika merujuk pada konsep 'Range of State' versi Randall Schweller, Amerika Serikat merupakan negara dengan range Lion. Hal tersebut berarti bahwa Amerika Serikat merupakan negara yang puas dengan sistem yang telah ada.

Ketika kekuatan status quo lebih kuat dibandingkan negara revisionis, maka status sistem akan tetap stabil. Namun, jika kekuatan revisionis lebih kuat daripada pembela status quo, maka sistem pada akhirnya akan berubah. Hal inilah yang diantisipasi Amerika Serikat dari pengembangan senjata nuklir Korea Utara beserta dinamika hubungan di Asia Timur. Jika Amerika Serikat gagal untuk menekan Korea Utara sebagai Revisionist state yang cenderung bertindak agresif, maka sistem akan berubah. Perubahan yang terjadi juga tentunya akan mempengaruhi status atau posisi Amerika Serikat di sistem internasional.

Tíndakan Amerika Serikat dalam keterlibatannya di proses denuklirisasi

Korea Utara selalu mengalami perubahan (baik secara diplomatik maupun koersif).

Perubahan tindakan ini juga dipengaruhi oleh pergantian kepemipinan di

${ }^{168}$ Hee Jea Lim.. Hlm. 7 
Amerika Serikat. Namun, tujuan dasar Amerika Serikat tidak pernah berubah. Tujuan primer dari negara ini adalah Self Preservation yang meliputi kepentingan untuk memaksimalkan keamanan (Maximizing Security) dan mempertahankan posisi (Mantaining Position). Hal ini sesuai dengan strategi nasional pertahanan Amerika yang menyebutkan $1 \%$. military forces needed to deter war and protect the security of our nations". 169

\subsubsection{Maximizing Security}

Terdapat perdebatan mengenai kepentingan negara Status Quo, yaitu memaksimalkan keamanan atau memaksimalkan power mereka. Menurut Waltz, setiap negara memang memiliki kepentingan untuk mempertahankan keamanan negaranya. Jika negara tersebut merupakan negara status quo, maka negara tersebut akan tetap memaksimalkan keamanannya walaupun tingkat keamanan yang dimaksimalkan tidak sama dengan negara lainnya. ${ }^{170}$ Hal tersebut dikarenakan, dalam anarki, keamanan adalah akhir tertinggi yang dicapai oleh negara. Jika negara memiliki keamanan yang terjamin, maka ketenangan, keuntungan, maupun power akan mudah untuk diraih sehingga Amerika Serikat dalam hal ini juga memiliki kepentingan untuk memaksimalkan keamanannya. Untuk memaksimalkan keamanan maka kepentingan yang harus dicapai Amerika Serikat adalah sebagai berikut :

1. Mempertahankan identitas independen

Sebagai negara yang independen, Amerika Serikat merupakan negara yang

tetap berupaya untuk tidak bergantung kepada negara lain. Negara ini justru akan

\footnotetext{
169 Jim Mattis. "National Defense Strategy of The United States of America". Departemen Pertahanan Amerika Serikat. 2018 : hlm. 1

${ }^{170}$ Randall L. Schweller. "Bandwagoning for Profit : Bringing the Revisionist State Back In". HIm. 85
} 
membuat negara-negara lain memiliki ketergantungan agar bisa mendominasi. Sebagai super power, Amerika Serikat akan berupaya menghadapi ancaman agresif, mencari sekutu, dan membangun kekuatan militernya. ${ }^{171}$ Rasa tidak aman mendorong negara untuk mencari kekuatan relatif. ${ }^{172}$ Hal ini menyebabkan anggaran militer Amèrika Serikat terus meningkat dari tahun ke tahun. Berikut merupakan anggaran dasar pertahanan Amerika Serikat :

\section{Grafik 4.1}

Anggaran Dasar pertahanan Amerika Serikat 2013-2018 (dalam juta Dolar Amerika Serikat)

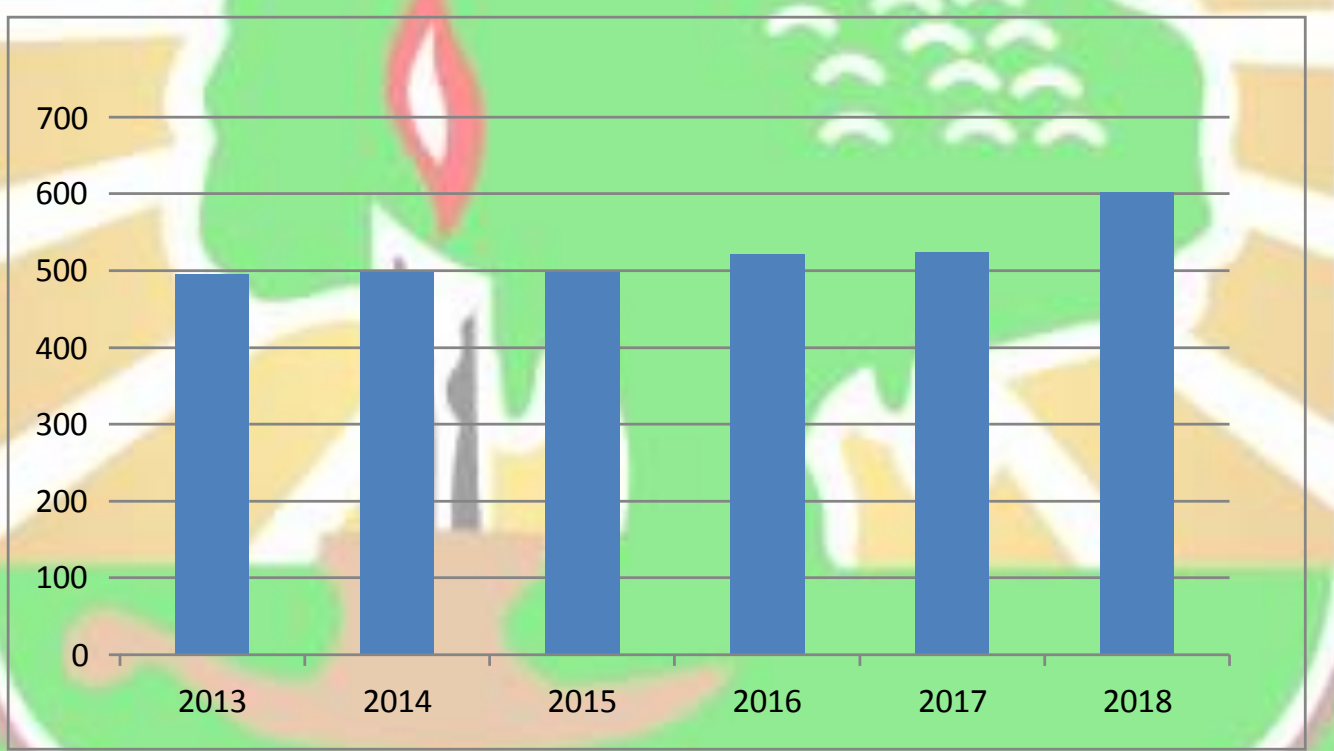

Sumber : DoD Topline Funding 2010-2024 ${ }^{173}$

Dari grafik dapat dilihat bahwa anggaran militer Amerika Serikat meningkat dari tahun 2013 smpai tahun 2013. Hal ini dikarenakan Amerika Serikat merasa ancaman nuklir Korea Utara dapat mempengaruhi identitas Amerika Serikat. Kepentingan ini juga sesuai dengan tindakan Amerika Serikat

\footnotetext{
${ }^{171}$ Jennifer M. Lind. "Pacifism or Passing the Buck?” International Security.MIT Press. 2004 : hlm. 104

${ }^{172}$ Jihwan Hwang. "Realism and U.S Foreign Policy toward North Korea." World Affairs (167), 2004: Hlm. 17

${ }^{173}$ Secretary of Defense. "Defense Budget Overview". United States Departement of Defense Fiscal. 2019 : Hlm.
} 
dalam melakukan latihan gabungan USFK di Korea Selatan. Kekuatan militer ini digunakan untuk menekan Korea Utara, seperti yang dilakukan pada tahun 2017. Dengan terwujudnya denukirisasi, Amerika Serikat bisa mempertahankan kepada pertahanan dan keamanan negaranya. Selain itu, Amerika Serikat juga bisa menghindari perang dan mencapai kepentingannya yang lain. LAS

Selain itu, sebagai negara pemenang Perang, Amerika Serikat dan keempat negara lainnya memiliki hak untuk memiliki senjata nuklir. Identitas ini akan terganggu jika negara lainnya memiliki senjata nuklir. Hal ini dikarenakan Amerika Serikat dan negara pemiliki resmi nuklir lainnya, mengklaim bahwa kepemilikan senjata nuklir mereka adalah untuk menjaga stabilitas keamanan. Sementara, negara non pemilik tidak berkomitmen untuk menjaga perdamaian. Oleh karena itu, denuklirisasi Korea Utara juga penting untuk mempertahankan identitas negara pemilik nuklir yang resmi sesuai NPT. ${ }^{174}$

2. Mempertahankan perdagangan positif ${ }^{175}$

Meskipun isu nuklir Korea Utara merupakan permasalahan di bidang keamanan, tetapi bukan berarti isu ini tidak berdampak kepada bidang lain seperti ekonomi. Aktivitas Korea Utara dinilai mengganggu kestabilan kawasan dan hubungan perdagangan Amerika Serikat dengan negara-negara di Asia Timur, bahkan dengan Korea Utara. Uji coba nuklir membuat Amerika Serikat mempertimbangkan akan memutuskan hubungan ekonomi dengan seluruh negara yang melaksanakan hubungan dagang dengan Korea Utara. ${ }^{176} \mathrm{Hal}$ ini dilakukan

\footnotetext{
${ }^{174}$ Inda Mustika Permata. Hlm. 108

${ }^{175}$ Randall L. Schweller. 'New Realist Research on Alliance : Refining, not Refuting, Walt'z Balancing Preposition". hlm.928

${ }^{176}$ BBC Indonesia. "Nuklir Korut : Korsel latihan Rudal, AS ancam 'pembalasan militer besarbesaran”. 4 September 2017. Diakses dari https://www.bbc.com/amp/dunia-41144846 pada 10 desember 2019.
} 
Amerika Serikat dalam beberapa pembentukan UNSCR nomor 1874, 1887, dan 2094.

Jika isu nuklir ini tidak cepat diselesaikan maka Amerika Serikat akan sulit mempertahankan perdagangan yang positif karena pada saat ini. Selain itu, Tiongkok juga merupakan kompetitor Amerika Serikat dalam bidang ekonomi yang bisa mempengaruhi hubungan dagang Amerika Serikat dengan negara lain.. "China is strategic competitor using predatory economics.." ${ }^{\prime 77}$. Menurut majalah The Economist, Tiongkok akan menyusul GDP Amerika Serikat pada $2018 .{ }^{178}$

Selain itu, nuklir Korea Utara juga dapat mengganggu stabilitas Jepang dan Korea Selatan di kawasan. Kedua negara ini merupakan partner ekonomi yang penting bagi Amerika Serikat. Jepang berada pada urutan keempat sebagai top trading partner bagi Amerika Serikat pada 2017 dengan total 204,2 milyar dolar Amerika Serikat. Sedangkan Korea Selatan menduduki urutan keenam dengan total 119,4 milyar dollar Amerika Serikat pada 2017. ${ }^{179}$ Jika kedua negara ini stabilitasnya terganggu dan tidak bisa melakukan perdagangan, maka Amerika Serikat akan kehilangan transaksi perdagangan sekitar 323,6 milyar dolar Amerika Serikat.

3. Meningkatkan integritas fungsional ${ }^{180}$

Dalam meningkatkan integritas fungsional, maka negara perlu memperhatikan pengaruh politik dan kekuatan pemimpin beserta struktur

177 Jim Mattis. hlm. 1

${ }^{178}$ Justin Logan. "China, America, and Pivot to Asia." Policy Analysis (CATO Institute), 2013: Hlm. 12

${ }^{179}$ Sarah Gray. "These are the Biggest U.S. Trading Partners". 7 Maret 2018. Diakses dari https://www.fortune.com/2018/03/07/biggest-us-trade-partners/amp/ pada 15 Desember 2019

${ }^{180}$ Randall L. Schweller. “Neorealism's Status Quo Bias : What Security Dilemma?”. Hlm. 102 
pemerintahan lainnya. ${ }^{181}$ Masyarakat Amerika Serikat dan struktur pemerintahan lainnya setuju bahwa nuklir Korea Utara perlu diakhiri. Hal ini memperlihatkan untuk meningkatkan integritas fungsional, Amerika Serikat memang perlu mengeliminasi dan menghapus segala infrastruktur pengembangan senjata nuklir Korea Utara. TIJ ERSITAS ANDALAS

Selaku pemimpin Amerika Serikat, Trump memiliki tanggungjawab untuk mempertimbangkan tindakan atau upaya yang akan diambil terkait isu internasional. Sesuai dengan neorealisme klasik, negara tidak bisa hanya berfokus kepada salah satu dari sistem atau unit (domestik). Oleh karena itu, denuklirisasi berusaha diwujudkan untuk memenuhi input dari domestik dan sistem internasional sendiri. Begitu pula yang dilakukan oleh pemimpin Amerika Serikat lainnya.

Senat Demokrat Amerika Serikat mengirimi Donald Trump surat mengenai desakan untuk tindak lanjut permasalahan denukirisasi Korea Utara. Surat itu mengandung pernyataan "We write to express our grave concern regarding your policy and diplomacy with North Korea" dan "and to urge you to redouble efforts to forge a succesfull and durable path toward denuclearization of North Korea..". ${ }^{182}$ dari pernyataan tersebut, dapat dilihat bahwa bukan hanya Presiden Amerika Serikat yang menginginkan denuklirisasi. Dikarenakan nuklir Korea Utara memang dianggap ancaman oleh masyarakat, struktur pemerintahan, dan aliansi regional Amerika Serikat maka pemimpin Amerika Serikat perlu

${ }^{181}$ Randall L. Schweller. "New Realist Research on Alliance : Refining, not Refuting, Walt' $z$ Balancing Preposition". hlm.928

${ }_{182}$ Paul LeBlanc dan Zachary Cohen. "Senate Democrats Urge Diplomatic Action Against North Korea As Trump Downplay Tests". CNN Politics. 6 September 2019. Diakses dari https://amp.cnn.com/2019/09/06/poitics/democrats-north-korea-trump-denuclearizationun/index.html pada 15 Desember 2019 
mewujudkan denuklirisasi sebagai upaya mencapai integrasi fungsional. Jika integritas fungsional terwujud, maka Amerika Serikat akan lebih mudah untuk mencapai kepentingan lainnya.

\subsubsection{Maintaining Position}

Sebagai negara Lion, RAmerika Serikat merupakan negara yang berperan dalam mengatur dan mengelola sistem internasional. Di level sistemik, Amerika Serikat akan berupaya melakukan distribusi kapasitas untuk tetap memiliki posisi sebagai pengelola dan penerima manfaat dari sistem yang dikelolanya. Hal ini membuat Amerika Serikat juga bertujuan untuk mencegah adanya perubahan dalam sistem, khususnya yang dapat mengancam posisinya. Untuk mempertahankan posisi, maka negara ini harus mencapai kepentingan sebagai berikut :

1. Mempertahankan aliansi

Di Asia Timur, Jepang dan Korea Selatan merupakan aliansi Amerika Serikat di bidang ekonomi maupun pertahanan. Aliansi antara Amerika Serikat dan Korea Selatan terikat dalam Mutual Defense Treaty. Sedangkan Amerika SerikatJepang terikat dalam US-Japanese Security Treaty. Ikatan ini menguntungkan semua pihak yang beraliansi, seperti saling mendukung saat salah satu pihak sedang membutuhkan bantuan dan dukungan. Contohnya Korea Selatan pernah mendukung Amerika Serikat dalam kampanye perangnya terhadap Vietnam dan Irak. ${ }^{183}$ Begitu pula yang dilakukan oleh Jepang sehingga Amerika Serikat juga harus memberikan bantuan kepada Jepang dan Korea Selatan saat mereka terancam di kawasannya.

${ }^{183}$ Edward Giovanny Marpaung. Aliansi Militer Amerika Serikat dan Korea Selatan dalam Upaya Menjaga Stabilitas Keamanan Semenanjung Korea (2010-2016). Bandung: Universitas Komputer Indonesia, 2017. Hlm. 2 
Dalam mempertahankan posisi, Amerika Serikat perlu juga mempertahankan pihak yang menjadi sekutunya. Dalam upaya denuklirisasi Korea Utara, Amerika Serikat tentu mencoba melindungi aliansinya Korea Selatan, dan juga Jepang, agar terhindar dari ancaman nuklir Korea Utara. Jika perlindungan telah berhasil dilakukan maka aliansi akan tetap bertahan menjadi pihak yang mendukung Amerika Serikat dalam mengelola sistem internasional. Kepentingan ini sesuai dengan pernyataan "Collectively, our force posture, alliance, and partnership architecture, and department modernization will provide the capabilities and agility required to prevail conflict and preserve peace through strength. $"{ }^{184}$

Oleh karena itu, Amerika Serikat membangun pertahanan rudal balistik THAAD di Korea Selatan untuk melindungi aliansinya ini dari ancaman nuklir Korea Utara. Selain itu, Amerika Serikat juga melakukan latihan gabungan dengan Jepang dan Korea Selatan. Pada tahun 2017, latihan gabungan antara Jepang dan Amerika Serikat melibatkan 14.000 tentara Amerika Serikat, kapal induk, dan kelengkapan perang lainnya. ${ }^{185}$

2. Mempertahankan prestise

Sejak berakhirnya Perang Dingin, Amerika Serikat merupakan negara yang paling mendominasi sistem internasional. Hal tersebut dikarenakan Amerika menduduki posisi teratas sebagai negara dengan kekuatan militer dan kapabilitas ekonomi dunia. Sebagai negara dominan, maka Amerika Serikat memiliki prestise yang tinggi untuk membuat sistem internasional tetap stabil di bawah kendalinya, terutama sistemyang telah ada di Asia Timur pada saat ini. Maksudnya, Amerika

\footnotetext{
${ }^{184}$ Jim Mattis. "National Defense Strategy of The United States of America". Departemen Pertahanan Amerika Serikat. 2018 : hlm. 1

${ }^{185}$ Meidy Amanda. Hlm. 161
} 
Serikat perlu melindungi kedua aliansinya di kawasan ini. Dengan begitu, prestise Amerika Serikat sebagai negara yang melindungi aliansinya akan tetap bertahan. Jika Amerika Serikat tidak berhasil dalam mewujudkan denuklirisasi Korea Utara, maka negara ini juga tidak berhasil menjaga sistem yang sudah dikelolanya.

Dalam dokumen summary dari strategi pertahanan nasional Amerika Serikat terdapat pernyataan “..National Defense Strategy articulates our strategy to compete, deter, and win in this environment..". 186 pernyataan tersebut memperlihatkan bahwa Amerika Serikat memiliki kepentingan untuk berkompetisi, mencegah dan menang dalam dunia internasional. Dalam upaya denuklirisasi Korea Utara, Amerika Serikat berupaya untuk menghapus segala kegiatan dan infrastruktur nuklir Korea Utara untuk tetap mempertahankan prestise sebagai negara 'pemenang' dan penjaga perdamaian dunia. Berbeda dengan Tiongkok yang memiliki tujuan untuk stabilitas kawasan sedangkan Amerika Serikat menginginkan denuklirisasi yang bersifat CVID. Amerika Serikat terancam oleh kebangkitan Tiongkok dan Semenanjung Korea merupakan 'flash point' Amerika Serikat dan Tiongkok untuk berkompetisi. ${ }^{187}$

Untuk kepentingan prestise ini, Amerika Serikat melakukan beberapa tindakan. Pertama, Amerika Serikat mampu mendorong pembuatan UNSCR yang khusus ditujukan pada Korea Utara pada tahun 2009 dan 2013. Kedua, Amerika Serikat juga menekan Korea Utara dengan ancaman seperti ancaman perang tahun

\footnotetext{
186 Jim Mattis. "National Defense Strategy of The United States of America". Departemen Pertahanan Amerika Serikat. 2018 : hlm. 1

${ }^{187}$ Kim Min Hyung. "Why Provoke the Sno-US Competition in East Asia and North Korea's Strategic Choice". Journal of Strategic Studies. 2015:Hlm.5
} 
2017. ${ }^{188}$ Selanjutnya, Amerika Serikat juga memperlihatkan bahwa negara ini mampu melibatkan Korea Utara dalam pembicaraan bilateral pada 2018.

\section{3. $\quad$ Mencegah agresi (Frightened the Wolves)}

Salah satu tujuan dasar dari negara Lion ialah untuk mencegah pihak lain mencapai kemajuan dâlảm kemampuan relatifnya. Oleh karena itu, Amerika Serikat berupaya mewujudkan denuklirisasi Korea Utara untuk mencegah Korea Utara memiliki kemajuan yang dapat mengubah sistem yang ada. Korea Utara sendiri merupakan negara yang berada dalam range wolf karena mengembangkan dan menguji coba senjata nuklir sehingga menimbulkan terganggunya stabilitas kawasan. Dalam pandangan Amerika Serikat, Korea Utara juga merupakan 'rogue state' karena tidak pernah menepati janjinya untuk denuklirisasi. Seperti pada 2009, Korea Utara justru menarik diri untuk kerjasama dengan IAEA dan menguji coba nuklirnya setelah dilakukan negosiasi yang dibicarakan melalui Six Party Talks. ${ }^{189}$ Tindakan yang diambil Amerika Serikat dalam merespon hal ini ialah menambah pasukan USFK terutama sejak tahun $2009 .{ }^{190}$

Amerika serikat percaya bahwa penggunaan tekanan dan pengaruh akan mampu mengubah tindakan Korea Utara. ${ }^{191}$ Namun, denuklirisasi step by step telah dilakukan oleh Amerika Serikat, tetapi selalu gagal. ${ }^{192}$ Korea Utara selalu menawarkan diri untuk menyerah dalam uji coba nuklir dengan mendapatkan kebutuhan yang diperlukan negaranya, tetapi negara ini selalu tidak mematuhi

kesepakatan yang dicapai dengan terus mengembangkan dan menguji coba nuklir.

${ }^{188}$ CNN Indonesia." ResponNuklir Korea Utara, AS Ancam Aksi Militer Skala Besar". 4

September 2017. Diaksesdarihttps://m.cnnindonesia.com/internasional/201709033233257-113239201/respon-nuklir-korea-utara-as-ancam-militer-skala-besarpada 1 Desember 2019

${ }^{189}$ Windhy Dewitasari. Strategi Penangkalan Nuklir Korea Utara Periode 2003-2010. Hlm.54

190 Andrew Yeow. Hlm. 114

${ }^{191}$ Beina Xu. "The China-North Korea Relationship." CFR Journal, 2014:Hlm. 4

${ }^{192}$ Philip Zelikow. "How Diplomacy with North Korea Can Work”. Hlm. 3 
Contohnya seperti Persetujuan Korea Utara terhadap penghentian uji coba nuklir di Yongbyon pada 9 Februari 2012 dengan syarat pemberian bantuan Amerika Serikat terkait kebutuhan bahan-bahan makanan. ${ }^{193}$ Namun, setelahnya Korea Utara masih mengembangkan nuklir dan menguji coba kembali pada Desember 2012.

Dalam mencegah agresi, Amerika Serikat akan mencoba untuk mengancam Korea utara (Frightened the wolves) agar tidak melakukan tindakan yang mengganggu stabilitas lagi. Oleh karena itu, pada 2017 Amerika Serikat mengancam untuk mengirimkan armada perang besar-besaran ke Korea Utara jika Korea Utara tidak berhenti menguji coba misilnya. ${ }^{194}$ Amerika Serikat juga membangun terminal pertahanan THAAD di Korea Selatan untuk merespon uji coba nuklir Korea Utara serta melakukan latihan perang gabungan dengan Jepang dan Korea Selatan. Ancaman-ancaman ini digunakan untuk 'menakuti' atau menekan Korea Utara bahwa Amerika Serikat adalah negara yang kuat sehingga Korea Utara mau melakukan negosiasi untuk denuklirisasi.

Jika denuklirisasi berhasil diwujudkan, maka Amerika Serikat telah berhasil untuk mencegah agresi yang dilakukan oleh negara 'nakal'. Dalam upaya perwujudan denuklirisasi Korea Utara, dapat dilihat bahwa Amerika Serikat sebagai negara 'lion' ingin memperlihatkan bahwa ia mampu mengontrol 'wolf' (Korea Utara) untuk tidak melakukan tindakan yang mengganggu ketertiban dunia. Hal ini tentunya akan mendorong negara lain untuk tetap mengikuti sistem yang ada dan tidak mencari masalah dengan negara 'penguasa'.

\footnotetext{
193 Thufeil Izharuddin. "Pengaruh Kebijakan Amerika Serikat di Semenanjung Korea dalam Proses Reunifikasi Korea (2011-2013)". Hlm. 30

${ }^{194}$ CNN Indonesia. "Respon Nuklir Korea Utara, AS Ancam Aksi Militer Skala Besar". 4 September 2017. Diakses dari https://m.cnnindonesia.com/internasional/201709033233257-113239201/respon-nuklir-korea-utara-as-ancam-militer-skala-besar pada 1 Desember 2019
} 


\section{BAB V}

\section{KESIMPULAN}

Sejak Korea Utara mengembangkan senjata nuklirnya, Amerika Serikat merupakan negara yang banyak terlibat dalam proses denuklirisasi. Keterlibatan tersebut dapat dilihat dari tindakan diplomasi maupun koersif untuk mendorong adanya denuklirisasi. Pertemuan antara Kim Jong Un dan Donald Trump di

Singapura pada 2018, merupakan sebuah kemajuan yang terjadi dalam dinamika hubungan Amerika Serikat dan Korea Utara. Adapun tujuan dari pertemuan bilateral ini ialah pembicaraan mengenai kelanjutan denuklirisasi Korea Utara.

Pengembangan nuklir Korea Utara sendiri tidak terlepas dari pengaruh dinamika hubungan Korea Utara dengan negara Asia Timur. Hal ini dikarenakan Korea Utara memiliki hubungan yang kurang baik dengan beberapa negara di Asia Timur. Pengembangan senjata nuklir oleh negara non-pemilik senjata nuklir memang selalu menyita perhatian. Implikasi dari nuklir Korea Utara terhadap dunia internasional sendiri adalah menciptakan ancaman baru terhadap sistem internasional, terutama di kawasan Asia Timur. Ancaman ini dinilai dapat mengubah stabilitas sistem yang telah ada dan mengganggu keamanan Jepang dan Korea Selatan. Secara tidak langsung, hal ini dapat mengancam posisi Amerika Serikat di Asia Timur. Oleh karena itu, Amerika Serikat ikut serta dalam upaya mewujudkan denuklirisasi Korea Utara.

Peneliti menemukan bahwa Amerika Serikat merupakan negara yang berada dalam posisi Lion. Hal tersebut dikarenakan Amerika Serikat merupakan negara (yang saat ini) berada dalam 'first rank', yang mana negara ini menduduki 
posisi pertama sebagai negara paling kuat dalam perekonomian dan pertahanan. Selain itu, negara ini juga melakukan tindakan balancing dalam mewujudkan denuklirisasi Korea Utara. Menurut Range of State Interest miliki Randall L. Schweller, negara dengan range Lion memiliki tujuan primer untuk Self Preservation yang meliputi maksimalisasi keamanan dan mempertahankan posisi. Dalam memaksimalkan keamanannya, Amerika Serikat berupaya mempertahankan perdagangan positif, mempertahankan identitas independen, meningkatkan integritas fungsional. Sedangkan dalam mempertahankan posisi, Amerika Serikat berusaha untuk mempertahankan aliansi, Mempertahankan prestise, dan mencegah terjadinya agresi.

Pertama, dalam mempertahankan perdagangan positif, Amerika Serikat perlu memastikan bahwa hubungan ekonomi dengan negara lain berjalan baik. Sementara itu, permasalahan nuklir Korea Utara membuat Amerika memiliki kendala dalam melanjutkan hubungan ekonomi, khususnya negara yang memberikan bantuan kepada Korea Utara. Untuk itu, Amerika Serikat berusaha mempertahankan kepentingan untuk perdagangan yang positif dengan adanya denuklirisasi Korea Utara secara penuh.

Kedua, sebagai negara super power yang independen, Amerika Serikat perlu menahan ancaman dari negara aggressor untuk menciptakan keamanan yang stabil di negaranya. Hal ini dikarenakan jika keamanan negaranya terganggu, maka identitas Amerika Serikat sebagai negara super power akan dipertanyakan. Selanjutnya, pemimpin Amerika Serikat perlu mewujudkan integritas fungsional negaranya dengan mempertimbangkan seluruh kepentingan dari struktur pemerintahan, masyarakat dan aliansi yang telah dimiliki dalam menanggapi isu 
hubungan internasional. Dalam permasalahan nuklir Korea Utara, masyarakat, kelompok kepentingan, struktur pemerintahan juga aliansi sama-sama menilai Korea Utara sebagai ancaman. Oleh karena itu, kepentingan yang ingin dicapai Amerika Serikat dari denuklirisasi Korea Utara adalah integritas fungsional.

Dari sisi maintaining position, Amerika Serikat berupaya untuk mencapai beberapa kepentingan juga. Pertama, Amerika Serikat memiliki kepentingan untuk mempertahankan aliansi. Hal ini sesuai dengan yang dinyatakan dalam dokumen ringkasan strategi pertahanan nasional Amerika Serikat. Jika Amerika Serikat mampu mewujudkan denuklirisasi Korea Utara, maka Jepang dan Korea Selatan akan tetap mempercayai Amerik Serikat sebagai aliansi pertahanan mereka. Jika aliansi telah dipertahankan maka Amerika Serikat pun akan tetap memperoleh dukungan untuk mencapai kepentingan nasional lainnya.

Kedua, Amerika Serikat berusaha mewujudkan denuklirisasi karena mempertahankan prestise. Setelah berakhirnya Perang Dingin, Amerika Serikat merupakan negara yang menjadi peringkat atas dalam sistem internasional. Amerika Serikat tentu memiliki tanggungjawab untuk perwujudan perdamaian dunia. jika Amerika Serikat berhasil untuk mengeliminasi nuklir Korea Utara maka prestise Amerika Serikat sebagai super power yang menjaga ketertiban dunia juga akan tetap bertahan.

Kepentingan terakhir yang berupaya diwujudkan Amerika Serikat melalui denuklirisasi Korea Utara adalah mencegah agresi dan frightened the wolves'.

Seperti yang telah disebutkan sebelumnya, bahwa denuklirisasi bertujuan untuk menghindarkan sistem internasional yang telah ada dari ancaman para aggressor. Jika denuklirisasi terwujud, maka Amerika Serikat akan memperlihatkan bahwa 
'lion' akan tetap bisa mengontrol 'wolves' untuk tidak mengganggu ketertiban yang telah ada. Menurut penulis, inilah kepentingan utama yang ingin di capai oleh Amerika Serikat melalui upaya denuklirisasi Korea Utara. Hal tersebut dikarenakan, Amerika Serikat sebagai negara yang memperoleh keuntungan dari sistem yang ada (satisfied status quo state) bagaimanapun akan berupaya mempertahankan sistem agar tidak berubah.

Dalam bidang ekonomi, Amerika Serikat cenderung berusaha untuk mencapai kepentingan untuk mempertahankan hubungan dagang di Asia Timur. Di sisi lain, Amerika Serikat juga berupaya meningkatkan stabilitas politiknya melalui integrasi unit-unit domestiknya. Namun, Amerika Serikat lebih cenderung mencapai kepentingan untuk mempertahankan posisi, khususnya di Asia Timur. Hal ini dikarenakan kepentingan utama Amerika Serikat ialah untuk melindungi Korea Selatan karena terikat Mutual Defense Treaty. Dengan mempertahankan aliansinya maka Amerika Serikat akan tetap dapat mendominasi Asia Timur. 


\section{DAFTAR PUSTAKA}

Aldikawati, Mega. "Dinamika Hubungan Korea Utara-Korea Selatan dan Dampaknya terhadap stabilitas Keamanan di Kawasan Asia Timur Pasca Perang Dingin." Reunifikasi Korea, 2012: 42-46.

Amanda, Meidy. "Dilema Aliansi Amerika Serikat terkait Peningkatan Kapabilitas Militer Jepang." Jurnal Ilmu Sosial dan Ilmu Politik (Universitas Indonesia) 1 (2018): 159-169.

Anderson, Nicholas D. "Explaining North Korea's Nuclear Ambitions : Power and Position on the Korean Peninsula." Australian Journal of International Affairs , 2017: 1-21.

Arsyad, Rafika. "Peluang dan Hambatan Upaya Reunifikasi Korea pada Era Kim Jong Un." Jurnal PIR 3 (2018): 76-92.

Avery, Emma Chanlett, Dkk. "North Korea : U.S. Relations, Nuclear Diplomacy, and Internal Situation". Congressional Research Service. 2015

BBC News Indonesia. Kim-Trump tandatangani ‘kesepakatan' : Hubungan ASKorut akan berbeda sama sekali. Diakses dari https://www.bbc.com/indonesia/amp/dunia-44447915 pada januari 2019

BBC Indonesia. "Nuklir Korut :Korsel latihan Rudal, AS ancam 'pembalasan militer besar-besaran". 4 September 2017.

Diaksesdarihttps://www.bbc.com/amp/dunia-41144846pada 10 desember 2019.

Betts, Richard K. "Wealth, Power, and Instability : East Asia and United States after the Cold War." International Security (The MIT Press) 18 (1993- 1994): 3477.

Bramantya, Farel Akbar. Alasan Tiongkok Menolak Pembangunan Terminal High Altitude Area Defense di Korea Selatan tahun 2016. Surabaya: Universitas Airlangga, 2018.

Campbell, Kurt dan brian Andrews . "Explaining the US Pivit to Asia". London : Catham House. 2013

Cha, Victor D. "Japan's Engagement Dilemmas with North Korea." Asian Survey (University of California Press), 2014: 549-563.

Choi, Jong Kun. "The Perils of Strategic patience with North Korea." The Washington Quarterly 38 (2016): 57-72. 
Choi, Yeseong. U.S. Nuclear Strategy and North Korea's ICBM Capability : Changing South Korean Perceptions of U.S. Extended Detterence. Monterey : Naval Postgraduate School, 2018.

Chung, Sung Yoon. "North Korea-U.S. Summit :Can It Become Crative Black Hole." Online Series, Maret 21, 2018: 1-7.

Clark, Rob dan Jason Backfield. "A New Trichotomous Measure of World System Position Using the International Trade Network.' International Journal of Comparative Sociology (SAGE Publication) 50 (2009): 5-38.

CNN Indonesia."ResponNuklir Korea Utara, AS Ancam Aksi Militer Skala Besar". 4 September 2017.

Diaksesdarihttps://m.cnnindonesia.com/internasional/201709033233257113-239201/respon-nuklir-korea-utara-as-ancam-militer-skala-besarpada 1 Desember 2019

Coghlan, Colonel David. "Prospect from Korean Unification." Strategy Research Project, 2008: 2-37.

Combes, Kathrine. "Between Revisionism and Status Quo : China in International Regimes : China's Behaviour in the Global Trade, Non Proliferation and Environmental Regimes." POLIS Journal (University of Leeds) 6 (2012).

Davidson, Chase O. Neoclassical Realism and The Collapse of the 1994 Agreed Framework. Iowa State University, 2008.

Dewitasari, Windhy. Strategi Penangkalan Nuklir Korea Utara Periode 20032010. Universitas Indonesia, 2011.

Dormandy, Xenia dan Rory Kinane. Asia Pacific Security A Changing Role for the United States. London: Catham House, 2014.

Famega, Irwindi. Pendekatan Ideologi dalam Hubungan antara Korea Selatan dan Korea Utara (Studi Kasus: Dinamika dalam Proses reunifikasi Periode Pemerintahan Moon Jae In). Medan: Universitas Sumatera Utara, 2018.

Fitrah, Elpeni. "Analisis Pendekatan Trust Politic Korea Selatan dalam Penyelesaian Hambatan Reunifikasi di Semenanjung Korea." Insignia Journal of International Relations 5 (2018): 85-95.

Gangale, Thomas. Alliance Theory : Balancing, Bandwagoning, and Detente. San Francisco: San Francisco State University, 2003.

Global Fire Power. "United States Military Strength". diakses dari https://www.globalfirepower.com pada 10 Desember 2019 
Gray, Sarah. "These are the Biggest U.S. Trading Partners". 7 Maret

2018.Diaksesdarihttps://www.fortune.com/2018/03/07/biggest-us-tradepartners/amp/pada 15 Desember 2019

Green, Michael J. "The US-Japan Alliance : A Brief Strategic History." Asian Governments and Legal System, 2007: 25-30.

Hagstorm, Linus dan Marie Soderberg. "Taking JapanNorth Korea Relations Seriously: Rationale and Background." Paciffic Affairs 76 (2006): 373385.

Hwang, Jihwan. "Realism and U.S Foreign Policy toward North Korea." World Affairs (167), 2004: 15-29.

Izharruddin, Thufeil. Pengaruh Kebijakan Amerika Serikat di Semenanjung Korea dalam Proses Reunifikasi Korea (2011-2013). Jakarta: UIN Syarif Hidayatullah, 2016.

Jhonston, Alastair Lain. "Is china a Status Quo Power?" International Security (Harvard College and MIT Press) 27 (2003): 5-56.

Jim Mattis. "National Defense Strategy of The United States of America". Departemen Pertahanan Amerika Serikat. 2018.

Kamasa, Fransminggi. Perang Korea. Pustaka Narasi. 2014

Kim, Min Hyung. "Why Provoke the Sno-US Competition in East Asia and North Korea's Strategic Choice". Journal of Strategic Studies. 2015:1-20

Kristensen, Hans M, dan Robert Norris. "North Korean Nuclear Capabilities, 2018". Bulletin of Atomic Scientist. Vol. 74. No.1. Routledge. 2018

LeBlanc, Paul dan Zachary Cohen. "Senate Democrats Urge Diplomatic Action Against North Korea As Trump Downplay Tests". CNN Politics. 6 September 2019. Diaksesdarihttps://amp.cnn.com/2019/09/06/poitics/democrats-northkorea-trump-denuclearization-un/index.htmlpada 15 Desember 2019

Lee, Seong-Hyon. "The Shift of Security Environment in Northeast Asia : The U.S. China Conflict and Its Implications for Korea." Journal for Peace and Nuclear Disarmament, 2018: 1-11.

Lee, Sung Yoon. "North Korea's Revolutionary Unification Policy." Interational Journal of Korean Studies XVIII (2014): 121-137.

Lim, Hee Jea. Korea is Really Matter to U.S.? The Relationship about USFK and ROK-U.S. Alliance. Halmstad University, 2011. 
Lind, Jennifer M. "Pacifism or Passing The Buck". Internatioanl Security. MIT Press. 2004.

Logan, Justin. "China, America, and Pivot to Asia." Policy Analysis (CATO Institute), 2013: 1-27.

Manyin, Mark E. "Japan-North Korea Relations : Selected Issues." CRS Report for Congress, 2003: 1-17

Marpaung, Edward Giovanny. Aliansi Militer Amerika Serikat dan Korea Selatan dalam Upaya Menjaga Stabilitas Keamanan Semenanjung Korea (20102016). Bandung: Universitas Komputer Indonesia, 2017.

Mearshimer, Jhon. "The Tragedy of Great Power Politics". New York: W. Warton Company. Hlm. 157-158

Merriam Webster. Diakses dari https://www.merriamwebster.com/dictionary/denuclearize pada 20 Oktober 2019

Moren, R. G. S. "Reaksi Korea Utara terhadap Kebijakan Korea Selatan Memberhentikan Bantuan terhadap Korea Utara (2008-2011)." 2011: 1-10.

Muhammad, Simela Victor. "Perdamaian di Semenanjung Korea Pasca Pertemuan Moon Jae In dan Kim Jong Un." Kajian Singkat terhadap Isu Aktual dan Strategis (Pusat Penelitian Badal Keahlian DPR RI), 2018.

Murooka, Tetsuo dan Hiroyasu Akutsu. "The Korean Peninsula : North Korea's Growing Nuclear and Missile Threat and South Korea's Anguish". 2017

Nabil, Muhammad. "Diplomasi Six Party Talks dalam Proses Denuklirisasi Korea Utara Periode 2003-2009." Jurnal Hubungan Internasional, 2014.

Nainggolan, Poltak Partogi. "Kepentingan Strategis Amerika Serikat di Asia Pasifik." Politica 4 (2013).

Nanto, Dick K. "China-North Korea Relations." Congressional Research Service Journal, 2010: 1-22.

Olsen, Edward A. "Coping with the Korean Peace Process : An American View." The Korean Journal of Defense Analysis, 1997: 159-180.

P., Angga Aditama. "Konflik di Semenanjung Korea dan Pengaruhnya terhadap Keamanan Internasional." (Universitas Gajah Mada) 2012: 1-17.

Permata, Inda Mustika. "Analisis Konstruktivisme : Perilaku Korea Utara terhadap Denuklirisasi." Andalas Journal of International Studies 2 (2018): 104-116.

Petterson, Jhon. "Structure, Agency. and Translantic Relations in The Trump Era". Journal of European Integration. vol. 40 :5. 2018 
Planifolia, Vanilla. "Strategi Rebalancing Amerika Serikat di Kawasan Asia Pasifik." Jurnal Hubungan Internasional, 2017: 16-26.

Pollack, Jonathan D. No Exit: North Korea, Nuclear Weapons and International Security. Washington DC: Routledge, 2010.

Purwono, Andi dan Ahmad Saifuddin Zuhri. "Peran Nuklir Korut Sebagai Instrumen Diplomasi Politik Internasional". Jurnal Ilmu Politik Hubungan Internasional. Vol.7, No, 2 UNWAHAS. 2010

Qonita, Maulida Ibnaty. "Ananlisis Perubahan Kebijakan Luar Negeri Korea Selatan dalam Pemasangan Sistem Terminal High Altitude Area Defense (THAAD)." Journal of International Relations (Universitas Diponegoro) 5 (2019): 797-806.

Rahmadhani, Tia Panca. Analisis Perubahan Sikap Tiongkok terhadap Korea Utara tentang Isu Nuklir Semenanjung Korea tahun 2006-2018. Lampung: Universitas Lampung, 2019.

Rantung, Krisandhy Ertanto. Kebijakan Luar Negeri Amerika Serikat terhadap Program Pengembangan Nuklir Korea Utara pada Masa pemerintahan Barrack Obama. Bandung: Universitas Komputer Indonesia, 2016.

Rinna, Anthony V. "Russia's Strategic Partnership with China and Soth Korea : The Impact of THAAD." Asia Policy 13 (2018): 79-99.

Rosyada, Vina. Strategi Perdamaian di Semenanjung Korea . Surabaya: Universitas Islam Negeri Sunan Ampel Surabaya, 2019.

Schweller, Randall L. "Bandwagoning for Profit : Bringing the Revisionist State Back in." International Security, 1994: 72-107.

Schweller, Randall L. "Neorealism's Status Quo Bias : What Security Dilemma? ." Security Studies (Ohio State university), 1996: 90-121.

Schweller, Randall L. "Unanswered Threats : a Neoclasical Realist Theory of Underbalancing." International Security (MIT Press) 29 (2004): 159-201.

Secretary of Defense. "Defense Budget Overview". United States Departement of Defense Fiscal. 2019

SIPRI. SIPRI Yearbook 2019: Armaments, Disarmament, and International Security Summary. Yearbook, Stockholm: Stockholm International Peace Research Institute, 2019.

Siskawati, Febby. " Pengaruh Kebijakan Pertahanan Korea Utara terhadap tatanan Ekonomi di Asia Timur". Yogyakarta : Universitas Muhammadiyah Yogyakarta.2018 
Sugiyono. Metode Penelitian Pendidikan, Pendekatan Kuantitatif, Kualitatif, dan $R \& D$. Bandung: Alfabeta, 2012.

Syahrin, M Najeri Al. "Logika Dilema Keamanan Asia Timur dan Rasionalitas Pengembangan Senjata Nuklir Korea Utara." Journal of International Studies, 2018: 116-135.

United Nations Security Council. "UNSCR." Security Council Resolution 1874. Juni 17, 2009. https://www.unscr.com (accessed September 2, 2019).

United Nations Security Council. "UNSCR." Security Council Resolution 1887. September 24, 2009. https://unscr.com (accessed September 2, 2019).

United Nations Security Council. "UNSCR." Security Council Resolution. Maret 7, 2013. https://www.unscr.com (accessed November 10, 2019).

VOA Indonesia. "Uji ICBM Korea Utara dikutuk secara Internasional". 29 November 2019. diakses dari https://www.voaindonesia.com/amp/4141870.html pada 30 November 2019

Wicahyani, Alfina Farmaritia. Dampak Pengembangan Nuklir Korea Utara terhadap Kompleksitas Keamanan Regional Asia Timur. Universitas Indonesia, 2010.

Widayanti, Rahmalia Ayu. Instalasi Sistem pertahanan Rudal Terminal High Altitude Area Defense (THAAD) Amerika Serikat di Korea Selatan. Jember: Universitas Jember, 2018.

World Bank. Gross Domestic Product 2018. World Development Indicators Database, Washington DC: World Bank, 2019.

Xu, Beina. "The China-North Korea Relationship." CFR Journal, 2014: 1-6.

Xuetong, Yan. "The Instability of Security Environment in Northeast Asia : The U.S. China Conflict and its Implications for Korea". Journal for Peace and Nuclear Dissarmament. 2018.

Yeo, Andrew. "U.S. Military Base Realignment in South Korea." Peace Review (Taylor\&Francis Group), 2010: 113-120.

Zelikow, Philip. How Diplomacy with North Korea can Work.(2018) 
KEPENTINGAN AMERIKA SERIKAT DALAM PROSES DENUKLIRISASI KOREA UTARA

\begin{tabular}{l}
\hline ORIGINALITY REPORT \\
\hline SIMILARITY INDEX
\end{tabular}

2 "Origins and Evolution of the US Rebalance toward Asia", Springer Nature, 2015 Publication

3 Kim, Min-hyung. "South Korea's China Policy, Evolving Sino-ROK Relations, and Their Implications for East Asian Security : South Korea, China, East Asian Security", Pacific Focus, 2016.

Publication

4 Jeffrey W. Taliaferro. "Security Seeking under Anarchy: Defensive Realism Revisited", International Security, 01/2001 Publication

5 Jan Ludvik. "Strategic Patience Revisited: The Counterforce Effect", The Washington Quarterly, 